The

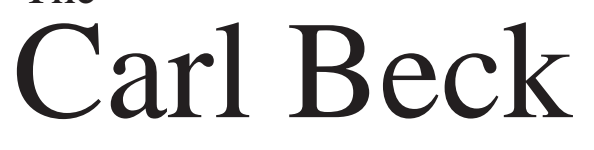

Papers

in Russian \&

East European Studies

Per A. Rudling

Number 2107

\title{
The OUN, the UPA and the Holocaust: \\ A Study in the Manufacturing of Historical Myths
}

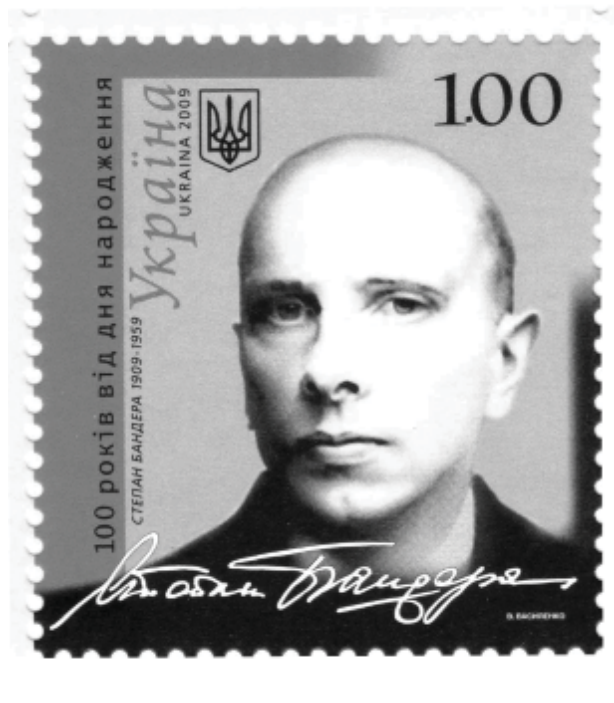


The

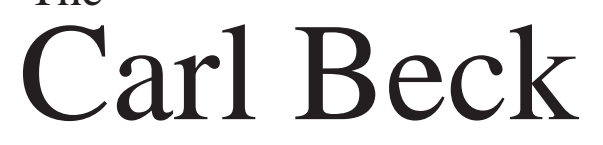

Papers

in Russian \&

East European Studies

Number 2107

Per A. Rudling

The OUN, the UPA and the Holocaust:

A Study in the Manufacturing of Historical Myths 
Per A. Rudling is a postdoctoral fellow at the Ernst-Moritz-Arndt-Universität Greifswald, Germany. His research interests include memory, identity, and nationalism in the Polish-Belarusian-Ukrainian borderlands.

No. 2107, November 2011

(C) 2011 by The Center for Russian and East European Studies, a program of the University Center for International Studies, University of Pittsburgh

ISSN 0889-275X

Image from cover: Ukrainian postage stamp of Stepan Bandera, released for the centennial of Bandera's birth. Image is within the public domain.

The Carl Beck Papers

Editors: William Chase, Bob Donnorummo, Ronald H. Linden, Andrew Konitzer Managing Editor: Eileen O’Malley

Editorial Assistant: Julie N. Tvaruzek

Submissions to The Carl Beck Papers are welcome. Manuscripts must be in English, double-spaced throughout, and between 40 and 90 pages in length, including notes. Acceptance is based on anonymous review. Mail submissions to: Editor, The Carl Beck Papers, Center for Russian and East European Studies, 4400 Wesley W. Posvar Hall, 230 South Bouquet Street, University of Pittsburgh, Pittsburgh, PA 15260. 


\begin{abstract}
During the past decade, particularly under the presidency of the third Ukrainian president Viktor Yushchenko (2005-2010) there have been repeated attempts to turn the leading figures of the Organization of Ukrainian Nationalists (OUN) and its armed wing, the Ukrainian Insurgent Army (UPA) into national heroes. As these fascist organizations collaborated with the Nazi Germany, carried out ethnic cleansing and mass murder on a massive scale, they are problematic symbols for an aspiring democracy with the stated ambition to join the European Union. Under Yushchenko, several institutes of memory management and myth making were organized, a key function of which was to deny or downplay OUN-UPA atrocities. Unlike many other former Soviet republics, the Ukrainian government did not need to develop new national myths from scratch, but imported ready concepts developed in the Ukrainian diaspora. Yushchenko's legitimizing historians presented the OUN and UPA as pluralistic and inclusive organizations, which not only rescued Jews during the Holocaust, but invited them into their ranks to fight shoulder to shoulder against Hitler and Stalin. This mythical narrative relied partly on the OUN's own post-war forgeries, aimed at cover up the organization's problematic past. As employees of the Ukrainian security services, working out of the offices of the old $\mathrm{KGB}$, the legitimizing historians ironically dismissed scholarly criticism as Soviet myths. The present study deals with the myth-making around the OUN, the UPA, and the Holocaust, tracing their diaspora roots and following their migration back and forth across the Atlantic.
\end{abstract}


Brought to power by the so-called Orange Revolution, the administration of Ukrainian president Viktor Yushchenko (2005-2010) expressed a clear ambition to orient Ukraine away from Russia and toward the EU, NATO, and the Western world. One step in this direction was the reassessment of modern Ukrainian history. Old Soviet heroes were reexamined, and the anti-Soviet nationalist resistance to Soviet rule reinterpreted in heroic terms. This is all part of a long and painful process of nation building and national consolidation, as Ukraine moves away from Soviet historiography into nation-based history writing. ${ }^{1}$ Following independence, and particularly after the Orange Revolution, nationalist and diaspora historical interpretations were adopted as the basis for new national myths. This essay addresses one particularly sensitive and delicate part of this mythology, the relation of Ukrainian nationalists - the Bandera wing of the Organization of Ukrainian Nationalists, the OUN(b), and its armed forces, the Ukrainian Insurgent Army, the UPA - to the Jews, a polarizing topic which has come to have important political connotations. The purpose here is not to restore one single historical "truth." Rather, it is to study the political use of history, the manipulations of the historical record, by tracing the genealogy of a set of historical myths, circling key mythmakers, their choice of material, and its potential for political mobilization, impact and political consequences. ${ }^{2}$

The first part of this essay considers the legacy of the OUN and the UPA, their political ideology, goals, and political orientation. The second part is the story of the manufacturing of the legends of these organizations and the genealogy of these myths as they have migrated from Ukraine, developed within the diaspora community, and, after the fall of communism, been reimported to Ukraine. The third part examines the apologetic narrative of the myth-makers, the impact of the myths on Ukrainian society and on its neighbors after they were elevated to state ideology and promoted by the state security organs and government propaganda agencies. The essay concludes with an assessment of, and reflection upon, the consequence of the legitimizing narrative and its role in the rise of the far right in Western Ukraine following Yushchenko's defeat in 2010.

\section{The OUN, the UPA, and the Holocaust}

Founded in 1929, the Organization of Ukrainian Nationalists became the dominant political movement of the Ukrainian far right. It was formed out of a number of radical nationalist and fascist groups and was, initially, led by war veterans, frustrated by their failure to establish a Ukrainian state in 1917-1920. In the increasingly authoritarian political environent of interwar Poland, radicalized the Ukrainian nationalists.

\section{Fascism}

The term integral nationalism was applied to the OUN by the American historian John Armstrong. ${ }^{3}$ The term has stuck, and many pronationalist historians find it preferable to the term fascism, which today carries strong negative connotations and is used colloquially as a term of abuse. There is no contradiction between fascism and integralism, which is a variety 
within the fascist tradition. ${ }^{4}$ As for the OUN, integral nationalism is a problematic term. The Ukrainian nationalists themselves did not use it, whereas references to fascism and national socialism abound in nationalist texts from the 1930s and 1940s ${ }^{5}$ Belonging to a tradition of European generic fascism, the OUN emerged out of an amalgamation between the Ukrainian Military Organization and a number of other extreme right-wing organizations, such as the Ukrainian National Association, the Union of Ukrainian Fascists, and the Union for the Liberation of Ukraine. ${ }^{6}$ From the moment of its founding, fascists were integral to, and played a central role in, the organization. The OUN avoided designating itself as fascist in order to emphasize the "originality" of Ukrainian nationalism. ${ }^{7}$ In 1941 the organization split between a more radical wing, the OUN(b), named after its leader, Stepan Bandera, and a more conservative wing, the OUN(m), led by Andrii Mel'nyk. Both were totalitarian, antiSemitic, and fascist. In terms of tactics, the $\mathrm{OUN}(\mathrm{m})$ was more cautious and stayed loyal to Nazi Germany throughout the war, whereas the OUN(b) took a more independent line. The OUN $(m)$ was a smaller and weaker organization and plays a minor role in the nationalist myth-making today. The main focus of this essay is therefore the OUN(b) and its offshoots.

Roger Griffin offers a broad conceptual model to suggest an eclectic interpretation of fascism, seeing it as the main consequence of European society's yearning for a new beginning. ${ }^{8}$ Fascism was hardly a historic anomaly but a well-integrated part of the European history in the twentieth century. Following academic tradition, I refer to the generic fascist tradition to which the OUN belonged as fascism in lower case, while using upper case to refer specifically to Italian Fascism. ${ }^{9}$ The OUN shared the fascist attributes of antiliberalism, anticonservatism, and anticommunism, an armed party, totalitarianism, anti-Semitism, Führerprinzip, and an adoption of fascist greetings. Its leaders eagerly emphasized to Hitler and Ribbentrop that they shared the Nazi Weltanschauung and a commitment to a fascist New Europe. Franziska Bruder, the author of the most detailed study of the organization describes "[t] he OUN as a classic representative of a nationalist movement with fascist characteristics that appeared in East-Central Europe," an analysis shared by other non-nationalist scholars of the OUN. ${ }^{10}$

The ideology of the organization was heavily influenced by the philosophy of Dmytro Dontsov, Italian Fascism, Nietzsche, and German National Socialism, combining extreme nationalism with terrorism, corporatism, and the Führerprinzip. ${ }^{11}$ Dontsov translated the works of Mussolini, Hitler, Goebbels, Rosenberg, and Franco and published Ukrainian translations of their works in Visnyk and other OUN-affiliated intellectual journals. "'2 "Ukrainian nationalism uses the term nationalism in the same way German and Italian nationalisms use the terms 'National Socialism' and 'Fascism' . . Nationalisms: Fascism, National Socialism, Ukrainian nationalism, etc. are different national expressions of the same spirit," wrote Iaroslav Orshan, an influential OUN ideologue. ${ }^{13}$ The OUN slogan "The Nation Above Everything" was taken quite literally, as was the slogan "Ukraine for the Ukrainians." The Decalogue of the OUN explicitly called upon its members not to hesitate to enslave foreigners and "treat enemies of Your Nation with hatred and ruthlessness." 14 In 1936 Stepan Bandera indicated the magnitude of the crimes the OUN was prepared to consider in order to achieve 
this goal. "The OUN values the life of its members, values it highly; but —our idea in our understanding is so grand, that when we talk about its realization, not single individuals, nor hundreds, but millions of victims have to be sacrificed in order to realize it." 15

\section{Racism}

The maintenance of racial purity was an important call to the nationalist faithful. OUN members were guided by a list of behavioral rules the called "the 44 rules of life of a Ukrainian nationalist." Number 40 read: "Cherish motherhood as the source of re-generation of life. Make your family the ciborium for the racial purity of your Nation." 16 The OUN embraced a highly racialized discourse, borrowing heavily from the Nazi racial theoreticians Alfred Rosenberg and Hans Günther. ${ }^{17}$ "Raciology [rasoznavstvo] is the key to world history; mastering of the race is the path to world politics." 18 The commitment to racial purity and the preservation of the race were taken very seriously by nationalist activists who promoted national awareness to police the sexual relations of their imagined community. Mykola Sukhovers'kyi, an OUN(m) activist, reminisced about how they enforced ethnic separation among students in Chernivtsy, which in the interwar era was part of Romania:

In the "Zaporozhe" [student fraternity] we had decided that no member was allowed to marry an alien girl - a non-Ukrainian. That decision was made on the basis of Mykola Mikhnovs'kyi's Decalogue ${ }^{19}$ which was printed in the Samostiina Ukraina and which stated: "Don't marry a foreigner, since your children will become your enemies." It needs to be recognized that Ukrainians who married Romanian girls of course ceased to be good Ukrainians, and their children directly came to belong to Romanian culture. . . I came up with two suggestions: 1) if we want to preserve our order, then no aliens are supposed to be invited to our parties or dance courses and 2) we should invite Ukrainian girls only from peasant homes, from the surrounding areas. ${ }^{20}$

The OUN(b) perceived the nation as a biological organism:

The nation emerged organically. In the world there is a constant struggle for existence, development, and power. There is a struggle between the species: . . . dogs, cats, lions, eagles are animal species; peoples, nations, and tribes are human species (Ukrainians, Germans, Muscovites, Gypsies, and Jews); there are differences between humans, animals and plants, just as there are between human species. ${ }^{21}$

Family life must be of Ukrainian character. Its content: the parents (fathermother) and children have to be Ukrainians. Mixed marriages (UkrainianPolish, Ukrainian-Muscovite, Ukrainian-Magyar, Ukrainian-Jewish) will be banned, forming such unions will be made impossible. We regard their very existence and the making of such unions a crime of national treason. ${ }^{22}$

Central to the OUN's racism was the concern that miscegenation would lead to degeneration of the racial stock. 
Racial biology [Natsiia-Nauka] also underwrites these conditions. Professor Dr. St. Rudnyts'kyi, in his book On the Basis of Ukrainian Nationalism, writes that "mixed marriages with our neighboring peoples are disadvantageous," as they lead to the denationalization of many, and the degeneration of others. ... The reflex against mixed marriages is natural, as it rises out of the instinct of self-preservation and growth of the Nation. It is typical for all national[ly conscious] societies. Nations in the process of expansion strictly adhere to this law. For instance, in Germany racial laws determine the destiny of the people and of the individual throughout his entire life (The same is true for Italians, and others.) Peoples in decline (spiritually as well as physically) ignore this law, which appeals to the instinct of self-protection. They are deaf to the health and the growth of life. ${ }^{23}$

OUN propaganda material identified the Ukrainians in biological terms, but also with Biblical undertones: "Ukrainians are those who are blood of our blood and bone of our bone. Only Ukrainians have the right to Ukrainian lands and Ukrainian names, and Ukrainian ideas." ${ }^{24}$

The OUN embraced the romantic notion of a national revolution, a mixture of Cossack nostalgia, glorification of violence, and sacrifice in the name of the biologically defined nation. In the 1930s the OUN press contained enthusiastic references to the Hajdamaki uprising in which many Poles, Uniates, and Jews were slaughtered.

When this new, great day [of national revolution] arrives, we will have no mercy. There will be no cease-fire, the Pereiaslavl or Hadiach peace treaties will not be repeated. A new Zalizniak, a new Gonta will come. There will be no mercy, neither for the big, nor the small, and the bard will sing: 'And father slaughtered son. ${ }^{25}$

The 1935 program for the military education of OUN combatants stressed that "a fighter should not hestitate to kill his father, brother, or best friend if he gets such an order."26

\section{Anti-Semitism}

While the influences from Nazi Germany had a significant impact on the anti-Semitic attitudes of the OUN, the organization had its own anti-Semitic tradition, independent of the Nazis. ${ }^{27}$ Ukrainian nationalism in Galicia had developed a narrative already in the late nineteenth century, complete with an elaborate anti-Jewish discourse. ${ }^{28}$

The Ukrainian nationalist press of the 1930s carried anti-Semitic articles on a regular basis. ${ }^{29}$ Dontsov himself regularly published anti-Semitic articles in the OUN-affiliated press, either under his own authorship or as translations from the leading Nazi theoreticians. In a 1929 article in the journal Rozbudova Natsii, the OUN's "intellectual laboratory" and leading ideological journal, ${ }^{30}$ Iurii Mylianych described the Ukrainian Jews as "an alien and predominantly hostile body within our national organism" and urged Ukrainians to develop guidelines for a Ukrainian policy toward the Jews. 
How to deal with the Jews? We have over two million of them in Ukraine. ... Should we allow them to further abuse the Ukrainian national organism? Assimilate them? Take them in? Amalgamate them? Get rid of them from Ukraine? How? Expel them? Where? It is neither that easy to expel 2 million people, nor get rid of them altogether. Nobody wants them; everybody is only happy to get rid of them. In practice, other than the Spaniards, no single European Christian nation has been able to solve the Jewish problem in a fully satisfactory way. Various methods have been tried, and not a single one of them has solved this issue. ${ }^{31}$

In 1938, Volodymyr Martynets, the editor of Rozbudova Natsii, described Jews as a "parasitical," "morally damaging," "corrupting" and "hostile element," "racially unsuited for miscegenation and assimilation." Rather than violent pogroms and mass murder, Martynets' argued that "a total and absolute isolation of the Jews from the Ukrainian people" 32 would be a more effective solution to the "Jewish problem."

It is easier to liquidate 44,000 Jews using these methods, than to liquidate $3 \frac{1}{4}$ million with more radical methods. ... All of the possibilities, especially if combined, will decrease the current strength of Jewry and will not only bring an end to their expansion in our country, but assure a continuous decline in the number of Jews, not only through emigration, but also through the decline of their natural growth rate. As the Jews will not be able to make a living, the Jews will take care of this themselves." ${ }^{33}$

Visnyk subscribed to a conspiratorial worldview. It perceived Bolshevism as a tool of Jewish dominance. The United States, as well as the Soviet Union, were controlled by Jewry, nationalist ideologues argued, and Jewish interests were setting Britain, France, and the United States against Nazi Germany. Referring to the United States, Visnyk spoke of "120 million Aryans over the ocean, under the yoke of Israel." ${ }^{34}$ When Mussolini introduced anti-Semitic legislation in 1938, Visnyk approvingly cited the "practical realization" of the "Jewish question" in Fascist Italy. ${ }^{35}$ Nationalist intellectuals like Dontsov and Martynets presented the OUN with a racial theory. Their repeated rejection of assimilation suggests that the OUN had internalized and "wholeheartedly accepted" a full-fledged, racial, antiSemitic discourse by the late 1930s. ${ }^{36}$ The OUN described the 1918-1919 pogroms during the civil war in Ukraine as part of a "social liberation struggle." ${ }^{\text {" }} 7$ Radicalized over the 1930s, anti-Semitism became particularly prominent between 1939 and 1943, reaching a high point in 1941-1942..$^{38}$ Leading members of the Bandera wing wanted Ukrainian Jews killed or removed, and offered to participate in the process. ${ }^{39}$ In April 1941, the OUN(b) declared that they "combat Jews as supporters of the Muscovite-Bolshevik regime." propaganda directives in the following month demanded the destruction of the Jews: "Ukraine for the Ukrainians! . . . Death to the Muscovite-Jewish commune! Beat the commune, save Ukraine!"41 There is no shortage of radical, even eliminatory, anti-Semitism in the writings of senior OUN ideologues and intellectuals, either during the interwar period or following the outbreak of the war. ${ }^{42}$ During the Holocaust, the nationalist Ukrainian press in occupied 
Poland, Ukraine, Germany, and Bohemia published anti-Semitic articles commissioned or endorsed by the German authorities. ${ }^{43}$

\section{Nazi Germany and the Establishment of New national States in Central Europe}

The OUN cooperated closely with other fascist states and movements - Italy, Japan, Spain, and, in particular, Germany. It established contacts with the Iron Guard in Romania and later the Chetnik leader Draža Mihailović. ${ }^{44}$ The OUN's relations with the Ustaše were close; the organizations trained their terrorists together in Fascist Italy. The OUN assassinated several leading Polish politicians, among them Tadeusz Hołowko in 1931 and Bronisław Pieracki in 1934, and provided the Ustaše assistance in the assassination of King Alexander I of Yugoslavia and the French foreign minister, Louis Barthou, in $1934 .{ }^{45}$ In the second half of the 1930s, its relations with Nazi Germany were close. In September 1937, Volodymyr Martynets' represented the OUN at the Fifth Congress of National Socialists Abroad (fünfte Reichstagung des NSDAP-Verbandes der Auslandsdeutschen) in Stuttgart. ${ }^{46}$

The OUN also supported German efforts to undermine Czechoslovakia. ${ }^{47}$ Under German tutelage, Slovakia declared independence on March 14, 1939. Two days later the Slovak leader, Monsignor Jozef Tiso, declared that his state would remove its national minorities "in a Christian way," without "cruelty" and "hatred," starting with the Czechs, and with the Jews to follow..$^{48}$ The Slovak constitution, which was modeled on Mussolini's Italy, Salazar's Portugal, and Schussnig's Austria, made the clerical fascist Hlinka's Slovak People's Party-Party of Slovak National Unity (Hlinkova slovenská l'udová strana-Strana slovenskej národnej jednoty, HSL'S-SSNJ) "the sole representative of the political will of the whole state." Jews and Gypsies were denied rights, Magyars and Ukrainians had their rights sharply curtailed. ${ }^{49}$ The emergence of an independent Slovakia indicated that Hitler was willing to break up multiethnic states and support the establishment of separate fascist states in Central and Eastern Europe. Other Central European fascists closely monitored the development in Slovakia. ${ }^{50}$ Yet Nazi Germany sent out mixed signals: it had opened a consulate in Transcarpathia in October 1938, but when Transcarpathia followed suit and proclaimed the Republic of Carpatho-Ukraine on March 15, Hitler did not recognize its independence, and its government had to flee within a few hours. ${ }^{51}$ In a May 2, 1939, letter to Joachim von Ribbentrop, the OUN leader Andrei Mel'nyk assured the German Foreign Ministry that the OUN Weltanschauung was closely related to that of the Nazis and the Fascists and offered to help in the "reorganization" of Eastern Europe..$^{52}$ On April 10, 1941, four days after the Wehrmacht entered Yugoslavia, the Ustaše declared the "resurrection" of the so-called Independent State of Croatia (NDH), ${ }^{53}$ a fascist state in which all political parties but the Ustaše were banned. ${ }^{54}$ The OUN(b) leadership in Krakow was electrified by the news from Zagreb and sent Ustaše leader Ante Pavelić a congratulatory telegram, enthusiastically greeting the establishment of the NDH. ${ }^{55}$ In April 1941, Andrii Mel'nyk, now the leader of the OUN(m), proposed to Hitler the creation of a Greater Ukraine, stretching from the Danube to the Caspian Sea ${ }^{56}$ Dreams of a Ukrainian empire had been nourished 
by both wings of the OUN, and the aspiration for territorial expansion was shared by all East-Central European fascist movements. ${ }^{57}$ Like their Slovak and Croatian counterparts, the OUN combined territorial expansion with a quest for ethnic "purity." 58 The OUN ideologue Mykola Stsibors'kyi envisioned the state as a "natsiokratiia" or a "natiocracy," an ethnically defined totalitarianism..$^{59}$ The OUN perceived a "Ukraine for the Ukrainians" as an ethnically cleansed totalitarian state, where all other political parties were to be banned. ${ }^{60}$ And, like Tiso's Slovakia, Pavelić's Croatia, and Antonescu's Romania, the OUN embarked on an eliminationist project to "purify" their nation of "alien" racial elements. ${ }^{61}$

\section{Barbarossa and Pogroms in Western Ukraine, 1941}

Following the German and Soviet invasion of Poland, many leading OUN members gathered in the German-occupied part of Poland, the General Governement. They were further radicalized by the brutal Soviet occupation of Western Ukraine in 1939-1941 and by the ideological and military training of many of their leaders by Nazi Germany from 1938-1939 onwards. ${ }^{62}$ Referring to itself as a "natural ally" of Nazi Germany and the Axis powers, the OUN(b) declared its readiness to go to war against the USSR. ${ }^{63}$

In Berlin on June 17, 1941, Reinhard Heydrich, the head of the Reich Security Main Office, gathered dozens of SS and police personnel to share with them his instructions regarding the encouragement of so-called self-cleansing actions. ${ }^{64}$ A week later, on June 25,1941 , in a letter to Bandera, Iaroslav Stets'ko wrote, "We are setting up a militia that will help remove the Jews and protect the population." ${ }^{65}$ Instructions issued to the OUN(b) militias urged them to cleanse the terrain of hostile elements.

In the time of chaos and confusion it is possible to permit the liquidation of undesirable Polish, Muscovite, and Jewish activists, especially supporters of Bolshevik-Muscovite imperialism. ${ }^{66}$

Destroy the officer staff, shoot the Muscovites, Jews, NKVD men, the political instructors, and all who want war and our death! ${ }^{67}$

The Jews are to be isolated, removed from positions to avoid sabotage, Muscovites and Poles even more so. If there is an absolute need to retain, for example, a Jew in the economic administration, one of our militiamen must be placed over him, and should liquidate him for the slightest transgression. Only Ukrainians, not foreign enemies, can be leaders in the various branches of life. The assimilation of Jews is excluded. ${ }^{68}$

OUN activists participated in the July 1941 pogroms, in which many of them displayed an above-average brutality. ${ }^{69}$ Upon their arrival in L'viv the commandos of the Ukrainian Nachtigall Battalion could rely on a fanatically anti-Semitic auxiliary contingent with good knowledge of local conditions. ${ }^{70}$ OUN flyers, distributed in the first days of the German invasion, urged the population: "Don't throw away your weapons yet. Take them up. Destroy 
the enemy ... People! —Know this! — Moscow, the Hungarians, the Jews — these are your enemies. Destroy them."

On June 30, 1941, the OUN(b) issued the "Act of Renewal Ukrainian Statehood" (Akt vidnovlennia Ukrains 'koi Derzhavy, or Akt), hoping that Ukraine would obtain a status similar to that of Tiso's Slovakia or Pavelić's Croatia. ${ }^{72}$ The twenty-nine-year-old firebrand Iaroslav Stets'ko presented himself as its prime minister on behalf of Stepan Bandera. ${ }^{73}$ His proclamation appears modeled on the Ustaše declaration, which it follows closely, but in its explicit references to Hitler it went further than the Slovaks and Croats. Stets'ko specified that the new state would "cooperate closely with National Socialist Greater Germany ... under the Führer Adolf Hitler." 74 On July 3, 1941, he sent letters to the other European fascist leaders: Hitler, Mussolini, Franco, and Pavelić, emphasizing that his state was a loyal member of the new, fascist Europe, the support of which he now sought. He explained to the Croatian Poglavnik Pavelić that "both revolutionary nations, hardened in battle, will guarantee the establishment of healthy circumstances in the Europe of the new order." 75

The declaration of Ukrainian statehood was accompanied by violent pogroms. Stets'ko's "government" expressed its willingness to annihilate the Jews of Ukraine, and Stepan Lenkavs'kyi, its main propagandist, advocated the physical destruction of Ukrainian Jewry. Stets'ko endorsed "the destruction of the Jews and the expedience of bringing German methods of exterminating Jewry to Ukraine, barring their assimilation and the like." Grzegorz Rossoliński-Liebe refers to the OUN(b) plans to evacuate or annihilate the ethnic minorites and replace them with "ethnic" Ukrainians to be resettled on "ethnic" Ukrainian lands as a Ukrainian Generalplan Ost. ${ }^{77}$ Between June 30 and July 3, 1941, massive pogroms claimed the lives of four thousand Jews in Lviv alone. ${ }^{78}$ The participation of OUN militias in the murder of Jews is well documented, from OUN correspondence with the Nazis, their own fliers and directives, down to movies and photos of Ukrainian militiamen in action. Some can be identified from the photos. ${ }^{79} \mathrm{OUN}(\mathrm{b})$ documents establish the collaboration between the Ukrainian militia and the Wehrmacht in joint Aktionen against Jews. ${ }^{80}$ Similar pogroms took place across Western Ukraine ${ }^{81}$ At least 58 pogroms are documented in Western Ukrainian cities, the estimated number of victims of which range between 13,000 and 35,000. ${ }^{82}$ The Nachtigall Batallion, consisting almost exclusively of OUN(b) activists serving in German uniforms under Shukheyvch's command, carried out mass shootings of Jews near Vinnytsia in July $1941 .^{83}$ Stets'ko described the pogroms in June 1941 as Ukrainian self-defense. ${ }^{84}$

The OUN(b) leadership hoped that, faced with a fait accompli, the Nazis would accept a fascist Ukraine as a vassal state. They were encouraged by signals from the circle around Alfred Rosenberg and within Abwehr, the German military intelligence service, who promoted a geopolitical vision in which the dismantled Soviet Union would be replaced by a reduced Muscovite Russia and a number of buffer states, including a Greater Finland, Baltica, Ukraine, and the Caucasus ${ }^{85}$ Hitler and his closest men opposed Ukrainian statehood, pursuing instead colonial plans of exploitation which greatly complicated OUN(b)Nazi relations. Bandera was arrested on July 5 and brought to Berlin, where he was put under house arrest. Bandera and Stets'ko appear to have continued clandestine political 
activities for some time. Not only the Nazis, but also the OUN(m) rejected the legitimacy of the June 30 declaration. On August 30, 1941, their senior activists Stsibors'kyi and Senyk were assasinated, in all likelihood by the OUN(b) ${ }^{86}$ On September 15 Bandera was again arrested and kept in a Berlin prison as an honorary prisoner until October 1943. He was then transferred to the Sachsenhausen concentration camp, north of Berlin, where he and Stets'ko were placed in comparatively comfortable confinement in the Zellenbau, a special barracks for high profile political prisoners. In October 1944 he was released and resumed his collaboration.$^{87}$ Other OUN(b) leaders, among them Roman Shukhevych and many future UPA commanders, continued to serve in German uniform until 1943. Thus, the OUN(b) "break" with Nazi Germany was half-hearted, and contacts were retained on several levels until the end, and even after the war.

\section{3: Political Reorientation After the Battle of Stalingrad}

The battles of Stalingrad and Kursk were major turning points in the war, foreshadowing the collapse of the Axis powers and forcing the OUN to reassess its strategy and search for new strategic allies. In the spring of 1943, armed OUN(b) units under Dmytro Kliachkivs'kyi and Roman Shukhevych took control of the Ukrainian Insurgent Army (Ukrains'ka Povstans'ka Armiia, UPA) from the group of Taras Bul'ba-Borovets', its original founder ${ }^{88}$ While these forces were anti-Semitic and carried out pogroms and murders of the local Jewish population, they rejected the fanaticism of the OUN(b) ${ }^{89}$ The original UPA, which had been created under the name Polis'ka Sich (the Polessie Riflemen), was loyal to the Ukrainian People's Republic in exile and refused to recognize Stets'ko's June 30 "renewal" of statehood as legitimate. ${ }^{90}$ When the UPA forces refused to subordinate themselves to the $\mathrm{OUN}(\mathrm{b})$, the Banderites took control by force and unleashed a campaign of terror in which many of the leaders of the original UPA were killed..$^{91}$

The new leadership consisted of ruthless OUN(b) activists, most of whom were trained by Nazi Germany, and many were deeply involved in the Holocaust. The Ukrainian gendarmerie, Hilfsfreiwillige (volunteers), and, in particular, the so-called Schutzmannschaften, had been central to the implementation of the Holocaust in Ukraine and Belarus. Often they were tasked with the dirty work, the Schmutzarbeit, of the Nazis, sealing off areas for the murder of Jews, communists, and pro-Soviet partisans. ${ }^{92}$ Among the UPA officers who had been trained by Nazi Germany or had served in the police, gendarmerie, and military organs, we find the supreme commander and the chief of the general staff of the UPA, the commanders or chiefs of staffs of all three areas of UPA activities (the UPA-North, UPA-West, and UPASouth), the commanders or chiefs of staff in at least nine out of eleven military districts. Since biographical data on the occupations of a large proportion of the UPA commanders are lacking for the years 1941-1943, the percentage of former policemen is likely to be higher. Former policemen constituted at least half of all UPA members from spring 1943 until the end of that year, and a very significant proportion thereafter. ${ }^{93}$

The OUN(b) expanded the UPA by means of a forced draft and the political terror created by its dreaded security service Sluzhba Bezpeki OUN (SB OUN). Thus, the UPA 
leadership came to consist of ruthless OUN(b) men, whereas many foot soldiers were forcibly drafted from the local population. Soviet and German reports both certify how discipline was maintained by terror. The Soviets wrote that

forty percent of the regular soldiers of the UPA are volunteers, the rest are forcibly mobilized. In the Rivne oblast' the men were mobilized by the threat of physical extermination. ... Desertions among the men forcibly mobilized into the UPA has increased in December 1943 in connection with the Red Army's successful advance into the territories of Western Ukraine. ${ }^{94}$

A German report from December 1943 gives the following description of the SB OUN:

The nationalist Ukrainian Insurgent Army has set up a 'security service.' We were able to arrest the representative of the 'national-Ukrainian security service' in the Rivne district. He said that this security service is a subordinate group of UPA and has the following tasks: extermination of Communist Party members, Poles and Germans, extermination of deserters, supervising of nonlocals, drafting young people into the Ukrainian nationalist movement and the Insurgent Army. ${ }^{95}$

\section{Murder}

The training provided by these collaborating forces was essential to the 1943-1944 UPA campaign of ethnic cleansing of Poles, Jews, and other minorities, the organization and execution of which closely resembles the anti-Jewish and anti-Partisan operations in 1941 and $1942 .{ }^{96}$ Philip Friedman, a pioneer on the history of Jews and the UPA, placed the UPA's anti-Jewish murders within the context of its cleansing of Western Ukraine of ethnic minorities: "Sometime in the winter of 1942-1943 the various Ukrainian partisan groups began an intense fight against all non-Ukrainians. Jews who escaped from the ghettos were seized on the highways, in villages, or in the forests, and were put to death." ${ }^{.97}$ The timing of the UPA's assault on the Jews largely coincides with the violent takeover of the organization by the OUN(b), with former auxiliary police men, known as Schutzmänner, particularly from the 201 Battalion, assuming command. Bul'ba-Borovets was horrified by the mass murders carried out by the new Banderite UPA leaders. Writes Karel Berkhoff: "According to Borovets', the Banderites (he mentions Lebed) imposed a collective death sentence on the Poles of "western Ukraine" in March 1943, sent him a list of demands in April that included their 'cleansing,' and instructed the UPA in June to complete the 'cleansing' operation as soon as possible." "98 In April 1943 Mykola Lebed', the acting leader of the OUN(b), advocated a policy "to cleanse the entire revolutionary territory of the Polish population." extermination" was organized by Dmytro Kliachkivs'kyi, known under the nom-de-guerre Klym Savur. ${ }^{100}$ The UPA's ethnic cleansing of the Poles in Volhynia and Galicia continued through 1943 and much of 1944, until the arrival of the Soviets. Whereas the UPA also killed Jews, Czechs, Magyars, Armenians, and other ethnic minorities, Poles were their main target. "Long live the great, independent Ukraine without Jews, Poles, or Germans. Poles behind the 
San, the Germans to Berlin, and Jews to the gallows," went one OUN(b) slogan in the late fall of 1941. ${ }^{101}$ UPA soldiers testify that orders to murder Poles often overlapped with those to murder surviving Jews, ${ }^{102}$ something that was reflected in the military songs of the UPA. An OUN song had the following lyrics: "We will butcher the Jews, strangle the Poles, and establish a Ukrainian state!" ${ }^{103}$ Another Polish survivor recalled that UPA soldiers passing through the Polish colony of Głęboczyca in Volodymyr-Volynskyi county singing: "Vyrizaly my zhydiv, vyrizhemo i liakhiv, i staroho, i maloho do iednoho; Poliakiv vyrezhem, Ukrainu zbuduiem" (We slaughtered the Jews, we'll slaughter the Poles, old and young, every one; we'll slaughter the Poles, we'll build Ukraine. $)^{104}$

The murderers used primarily farm tools - scythes, knives and pitchforks. ${ }^{105}$ Orthodox priests blessed such weapons in their churches. ${ }^{106}$ The bodies were often badly mutilated, partly as a byproduct of intimate murder, but were futher tampered with in order to dehumanize the victim and strike terror. Some had their stomachs cut open, noses cut off, or faces smashed in. The display of dismembered, crucified, or disemboweled bodies was meant to instill fear and panic and encourage the Volhynian Poles to flee. ${ }^{107}$ Polish and Jewish survivors' accounts emphasize the brutality of the murders. Moshe Maltz, a survivor, wrote in his diary:

When the Bandera gangs seize a Jew, they consider it a prize catch.... They literally slash Jews to pieces with their machetes. ${ }^{108}$

Bandera men ... are not discriminating about who they kill; they are gunning down the populations of entire villages. ... Since there are hardly any Jews left to kill, the Bandera gangs have turned on the Poles. They are literally hacking Poles to pieces. Every day ... you can see the bodies of Poles, with wires around their necks, floating down the river Bug. ${ }^{109}$

The OUN(b)'s reorientation toward the West in 1943 was accompanied by a change in ideology, following its third, extraordinary congress in August that year. The overt racism was toned down and official OUN-UPA statements were increasingly wrapped in a democratic and inclusive rhetoric, but their mass murder of national minorities continued unabated. ${ }^{110}$ The UPA's anti-Jewish violence culminated in late 1943 and early $1944 .{ }^{111}$ In what appears a deliberate strategy, surviving Jews were lured out of their hiding places and murdered. ${ }^{112} \mathrm{In}$ 1943, the security service of the OUN(b) in Volhynia issued orders to "physically exterminate Jews who were hiding in the villages." 113 The murders of Poles and Jews continued through the winter and spring of 1944. ${ }^{114}$ The estimates vary; Grzegorz Motyka estimates that the UPA killed one or two thousand Jews, mainly in Volhynia;115 John-Paul Himka estimates the number as "several thousand, but perhaps the number was much higher." 116 This should be put in relation to the documented 88,700 Polish victims of the UPA. ${ }^{117}$ The murders were carried out along ethnic lines in an area with many mixed Polish-Ukrainian families. Polish survivor testimonies contain gruesome accounts of how the UPA forced family members to take part in murders of their relatives. ${ }^{118}$

On the initiative of the OUN(b), negotiations with the SS and its Security Service (Sicherheitsdienst, SD) were resumed on March 5, 1944. Father Ivan Hryn'okh, who had 
served as army chaplain in the Nachtigall Batallion and Batallion $201^{119}$ and represented the OUN(b) in the negotiations, emphasized that

those who believe that the Bandera group considers the German Reich as their opponent are mistaken. The political situation in the Great Russian lands could have played out quite differently if the German Reich in 1941 had recognized the Ukrainian right to establish its own state administration. Without any doubt, Ukraine would have been satisfied with a state administration, such as a protectorate. But as this hope was not fulfilled, the Bandera group was forced to continue its illegal activities, yet strictly maintaining the rules not to attack German interests and aim all its forces toward the preparation for a decisive struggle against the Muscovites. ${ }^{120}$

By March 1944, the UPA was sharing information with the German authorities on their murder of "Poles, bandits, and Jews." Formal cooperation with the German Security Police, Sicherheitspolizei (SiPo) and the SD was resumed in May 1944. ${ }^{121}$ The German authorities released Bandera in October 1944. ${ }^{122}$

\section{Jews in the OUN-UPA?}

While the OUN and the UPA took part in the mass murder of Jews, there are examples of individual Jews surviving the Holocaust within the ranks of the UPA. The Holocaust changed not only the ethnic and cultural landscape of Western Ukraine. The murder of the Jews removed cobblers, tanners, smiths, and other professions in which the Jews had been prominent. Accounts of the war years show that people had problems with fur coats and boots falling apart, after the Jews were removed. The UPA suffered an acute shortage of nurses and doctors. John-Paul Himka describes the relationship between the UPA and individual Jews who survived the war within its ranks as "a marriage of convenience between a partisan unit desperately in need of doctors and nurses and Jews desperately in need of a place that would keep them out of the hands of the Germans." 123

Ukrainian sources speak of a considerable number of Jewish physicians, dentists, and hospital attendants who served in the ranks of the UPA. The question is: Why did only a small number of them remain alive? The Bandera groups also utilized other Jewish skilled workers. According to Lew Shankowsky, practically every UPA group had a Jewish physician or pharmacist, as well as Jewish tailors, shoemakers, barbers, and the like. Again the question arises: What happened to these hundreds or thousands of Jewish professionals and skilled workers? Betty Eisenstein states that in the spring of 1943 the Bandera groups began to imitate the German tactics of "selection." Only the skilled workers were left alive, and they were concentrated in special camps, where they worked at their trades or on the farms. One such camp, established in April 1943 near Poryck, Volhynia, contained more than 100 Jews. A second camp, which had some 400 Jews, was located in Kudrynki, nearly 20 miles from Tuczyn, Volhynia. Eisenstein reports that at the approach of the Soviet army the Bandera groups liquidated the Jews of the camps. ${ }^{124}$ 
In late 1943 and early 1944 some of the few remaining Jews of Western Ukraine were invited into the ranks of the UPA, but many were executed when the Soviets were approaching and they were no longer useful. ${ }^{125}$ The UPA had three main targets: Soviet partisans, Poles, and Jewish refugees, while Germans were generally exempt from UPA attacks. ${ }^{126}$ While antiGerman sentiments were widespread, according to captured activists, at the time of the Third Extraordinary Congress of the OUN(b), held in August 1943, its anti-German declarations were intended to mobilize support against the Soviets, and stayed mostly on the paper. They did not result in any major, or lasting changes in the OUN's relations to Nazi Germany. ${ }^{127}$ The OUN(b) leader Mykola Lebed' opposed military attacks on German interests, ${ }^{128}$ and Roman Shukhevych strongly opposed the decided anti-German actions, wanting to aim all attacks exclusively against the Soviets. ${ }^{129}$ UPA group North repeatedly requested permission to take up arms against the Germans, but the leadership always turned them down. ${ }^{130}$ There were, however, clashes. Six percent of the UPA and OUN(b) leaders, and 0.3 percent of the SB OUN leaders in Volhynia were killed by German forces. ${ }^{131}$

\section{Inventing a Comfortable Past}

The outcome of the battle of Stalingrad had changed the geopolitical situation and necessitated a reorientation. The OUN(b) now started to do away with its overtly fascist attributes. In February 1943 the Third Congress of the OUN(b) decided that raising the right arm was no longer to be considered an obligatory party salute ${ }^{132}$ and began to remove any references to it in their own documents. ${ }^{133}$ The leadership of the original UPA protested the OUN(b)'s violent takeover of their organization and found their hijacking of the UPA brand name cynical. Wheras the original UPA had indeed taken up arms against the Germans, senior OUN(b) leaders, among them Roman Shukhevych, had repeatedly volunteered their services to Nazi Germany and served in German uniforms until 1943. ${ }^{134}$ In an open letter to the OUN(b) leaders, Bul'ba-Borovets' reminded them that "when, in July of 1941 the Ukrainian Insurgent Army, the 'Polis'ka Sich,' started its armed resistance, you took a negative position, which you maintained until the last minute." 135 His observation was prophetic: the appropriation of the name UPA would indeed be used in post-1943 OUN(b) propaganda to whitewash its activities in 1941-1942 by predating its 1943 "break" with Nazi Germany. The manipulation of the OUN legacy forms an unbroken chain from 1943 until today. In October 1943, the OUN(b) embarked upon a project to revise its history, manufacturing a version more presentable to its new intended allies. In October 1943 the Homeland Leadership (Kraiovyi Provid) of the OUN in Western Ukraine ordered the preparation of

a special collection of documents which would affirm that the anti-Jewish pogroms and liquidations were carried out by the Germans themselves without the help of the Ukrainian police, and that, on the contrary, before the shootings, the Germans made the Judenrat . . . confirm the cooperation of Ukrainian police in the actions. ${ }^{136}$ 
The OUN(b) leaders issued explicit instuctions on how to blame pogroms and antiJewish violence on the Germans and Poles, ordering the preparation of

c. Lists that would confirm that the Germans carried out anti-Jewish pogroms and liquidations by themselves, without the participation or help of the Ukrainian police, and instead, before carrying out the executions, urged the Jewish committee or the rogues themselves to confirm with their signatures the presence of the Ukrainian police and its involvement in the actions.

d. Material that would clearly confirm that Poles had infiltrated and taken part in anti-Jewish pogroms and at the same time that they had served as the hirelings and agents of the Germans in their struggle with Ukrainians. ${ }^{137}$

One of these collections, "The Book of Facts" (Do pochatku knyha faktiv), was aimed at deflecting attention from OUN(b) and UPA participation in the Holocaust. Written in the form of a chronicle, and made to appear to date from 1941, this was an attempt to create a "convenient" set of documents, after it was clear that Germany was losing the war. ${ }^{138}$ It claimed that the Germans asked the OUN(b) to take part in a three-day pogrom in early July 1941, but that the OUN(b) regarded it as a German provocation, and refused. "The OUN leading activists informed themselves and informed the leading cadres that this was a German provocation to compromise Ukrainians through pogroms in order to give the German police a pretext to get involved and 'enforce order,' and, what is more serious, to divert the energy of the Ukrainian community from the political problems of the struggle for independent statehood, to the slippery road of anarchism, crimes, and violence."139

On November 1, 1943, the central command of the UPA issued a directive "to emphasize that we tolerate all nationalities - also Jews, who work toward Ukrainian statehood. They will remain Ukrainian citizens with full civic rights. Regarding this we need to talk to Jewish doctors and other professionals, who are part of our effort." ${ }^{140}$ Around the same time, the UPA published propaganda leaflets aimed at other ethnic minorities: Georgians, Uzbeks, Kazakhs, Turkmans, Poles, Belarusians, Russians, Czechs, and others. ${ }^{141}$ Pronationalist scholars often emphasize the UPA's multinational, internationalist nature when its murders of Poles, Jews, and other minorities are brought up. Whereas in 1942, OUN(b) flyers and posters commemorating the first anniversary of the declaration of Ukrainian "statehood" contained explicit anti-Semitic references, after 1943 the rhetoric changed. In 1947 and 1948, the OUN-UPA annual commemoration was presented as an oppositional, anti-German step. ${ }^{142}$ At this time, the OUN's denial of its own anti-Semitism was already categorical. In 1947, the OUN issued an English-language propaganda leaflet in post-war Poland, which maintained,

We have never edited nor spread nowhere . . . any anti-Jewish leaflets. In all our political literature, underground revolutionary papers and proclamations, neither now, nor at the time of the German occupation you would seek in vain if only one word [was] directed against the Jews. Like objections are nothing other as a sterling invective and lie. As well as we have never taken part in 
any anti-Jewish actions. ${ }^{143}$

Even though the OUN from 1943 denied its anti-Semitic legacy, its propaganda material still contained anti-Semitic undertones. ${ }^{144}$ The foreign section of the OUN(b), Zakordonna Chastyna OUN, or ZCh OUN, which could operate freely in the West, did not seek cooperation with Jewish (and Russian) émigré groups, and its leadership continued to embrace anti-Semitic stereotypes of Jews as the avant-garde of Bolshevism. ${ }^{145}$ Jews were not a "truly" national people, since they lacked a definite ethnograhic territory. Jews rarely figured in the post-war OUN material, as the organization regarded the Holocaust as having "resolved" the "Jewish question." 146 In March 1950, the OUN-UPA published a pamphlet, Jews - Citizens of Ukraine, declaring, in democratic, inclusive language that it regarded Jews as citizens in the state for which it was fighting. ${ }^{147}$ The anonymous authors of this one declaration aimed exclusively at the Ukrainian Jews, even refer to them by the Soviet term evrei, not their customary zhyd. The declaration, issued immediately after the killing of Shukhevych, at a time when the UPA was essentially defeated, is best understood as an attempt to woo the Western world and to seek its support as their insurgency was defeated. Yet, even this leaflet ends with a thinly veiled threat, based upon the same old stereotypes of Jewish disloyalty and communist leanings.

We, the Ukrainian revolutionaries turn to you:

Remember, that You are on Ukrainian land and that it is in Your own interests to live in agreement with its legitimate rulers - the Ukrainians. Stop being a fifth column in the hands of the Muscovite-Bolshevik imperialists. The moment when the times of Khmel'ntyskyi will be repeated is not too far away. Yet this time we would like it to take place without anti-Jewish pogroms. We do not want a repetition of what Your poets described in the following words:

Bitter tears were pouring

Over the souls of good and honest men,

Whose bloody was flowing

Like the water of mountain creeks.

Today, during the times of harsh struggle the Ukrainian people for its freedom, for national independence, we turn to You, Jews - citizens of Ukraine:

Remind those brothers of your nationality, whose hands are helping the Kremlin robbers crucify our people. Tell them to stop their criminal activities. ${ }^{148}$

Stepan Lenkavs'kyi was responsible for the propaganda activities of the Zakordonna Chastyna OUN, a key task of which was clearing the past of the movement itself. ${ }^{149}$ The Banderite narrative represented their own legacy as a "heroic Ukrainian resistance against the Nazis and the Communists" which had been "misrepresented and maligned" by "Moscow propaganda"; the OUN(b) and the UPA were fighting "not only for Ukraine, but also for all of Europe."”150

The OUN(b) regularly censored any documents that contradicted the image they wanted to produce - such as Stets'ko's 1941 declaration of loyalty to Hitler and Nazi Germany. The whereabouts of the many UPA leaders, who like Shukhevych served in German uniform 
in 1942, were omitted from their biographies, their break with the Nazis predated. By 1946 Shukhevych, who himself had actively opposed attacks on German interest, presented the OUN's activities in 1943 as "an armed insurgency, including the wide popular masses, in other words the entire Ukrainian people, in that struggle against the German occupant." "151 In 1948 the OUN activist Petro Poltava (a pseudonym), claimed that "the OUN under the leadership of Stepan Bandera conducted a massive struggle of the entire people [masovu vsenarodnu borot'bu] against the Hitlerite occupants in 1941-1944." 152 Other nationalist stories of OUN-UPA resistance against the Nazis, such as Kosyk and Stets'ko's postwar claims that the commander of the Nazi Stormtroopers, (the Sturmabteilung, SA) Viktor Lutze was killed by UPA unit in Volhynia in 1943, are entirely fictional. ${ }^{153}$ Nevertheless, these claims, uncritically repeated by pro-UPA historians came to enter the nationalist canon. ${ }^{154}$

\section{Diaspora Nationalist Myth-making: The Fanatics}

The Bandera group dominated heavily among Ukrainian émigrés-U.S. intelligence reports estimated that 80 percent of the Ukrainian Displaced Persons (DPs) from Galicia remained loyal to Bandera, who tried to establish a dictatorship in exile that would be transferred to a liberated Ukraine. They benefited from their pre-existing clandestine political network. In the immediate postwar period, Bandera was protected by a group of former SS men. ${ }^{155}$ The US Army Counterintelligence Corps (CIC) described him as "extremely dangerous," surrounded by bodyguards ready to "do away with any person who may be dangerous to him or his party. ${ }^{156}$

The OUN(b) maintained discipline by the use of systematic terror and kept kidnapping, murdering, and abusing political opponents well into the 1970s. The main center of its activity was in Bavaria, in the U.S. zone of occupation, where Evhen Lozyns'kyi was the local providnyk, or leader, for the OUN(b). ${ }^{157}$ West German police reports contain estimates that the Bandera movement carried out about one hundred assassinations in Germany after the war. ${ }^{158}$

In the immediate postwar years the OUN(b) split over its fascist legacy. Bandera denounced its democratic façade, which he called a tactical maneuver, and dismissed as "Sucking up to the West." 159 This led to a clash between the committed totalitarians Bandera, Stets'ko, Lenkavs'kyi, and their associates and the group around Mykola Lebed', Lev and Daria Rebet, and Ivan Hryn'okh, who wanted to retain the program of the Third Extraordinary Congress of the OUN(b). ${ }^{160}$ Bandera, who refused to give up the Führerprinzip, terrorism, and the conspiratorial methods, ${ }^{161}$ expelled members of the growing opposition, resulting in June 1948 in a full break between the Bandera-Stets'ko (ZCh OUN) and Lebed'-Hryn'okh groups (Foreign Representation of the Ukrainian Supreme Liberation Council Ukrains 'ka Holovna Vyzvol'na Rada, UHVR, Zakordonne Predstavnytstvo ZP UHVR). ${ }^{162}$ The hatred between Bandera and Lebed' became so personal and intense ${ }^{163}$ that Lebed' personally fired a gun at Bandera and ordered his followers to kill him. ${ }^{164}$ In 1948, the Bandera group planned to assassinate the Soviet foreign minister, Andrei Vyshinskii during his upcoming visit to the UN General Assembly in Paris. ${ }^{165}$ Bandera's group financed its terrorist actvities 
by producing counterfeit U.S. dollar bills. ${ }^{166}$ By 1951 they turned vocally anti-American, as the United States did not support the OUN aim of an independent Ukraine. ${ }^{167}$ The OUN(b) papers spewed anti-American rhetoric, their thugs terrorized political opponents among the émigrés, intimidating Ukrainians who worked for the United States. ${ }^{168}$ The CIA later lost interest in Bandera as an agent, as did the British MI6. ${ }^{169}$ By 1954, the CIA described Bandera as a "ruthless" "terrorist" and "bandit type," "politically unacceptable to the US Government." 170 The CIA would have liked to get rid of him and advocated the "political neutralization of Bandera as an individual." 171 At the same time it was concerned about Soviet plots against Bandera after a covert Soviet team had entered the American zone of Germany in June 1946 to kidnap him. ${ }^{172 ~ " T h e ~ S o v i e t s ~ a r e ~ n o t ~ a l l o w e d ~ t o ~ k i d n a p ~ o r ~ k i l l ~ h i m ~ . ~ . ~ . ~ u n d e r ~}$ no circumstances must Bandera be allowed to become a martyr." ${ }^{173}$ Instead, the OUN(b) oriented itself toward authoritarian right-wing dictatorships, whose support they sought.

The OUN(b) organized an umbrella organization for fascist and authoritarian east European movements, called the Anti-Bolshevik Bloc of Nations (ABN), linking former members of Tiso's government, former Nazis, Romanian Legionnaires, the successors of the Ustaše. It came to cooperate closely with Franco's Spain, and became an active participant of the World Anti-Communist League (WACL) ${ }^{174}$ The OUN(b) was negotiating with the Spanish authorities about providing training in Spanish military academies for former members of the UPA and the Waffen-SS division Galizien, a Ukrainian collaborationist formation established in April 1943. ${ }^{175}$ While Bandera's July 1954 audience with Franco was cancelled in the last minute, ${ }^{176}$ Stets'ko met with Franco and Chiang Kai-shek in 1955 and $1956 .{ }^{177}$ The OUN(b) sought to provoke a revolutionary uprising in the Soviet Union in order to split the Soviet army, get rebel control over Soviet nuclear weapons, seeking a nuclear confrontation with Moscow. ${ }^{178}$ The movement developed an intese cult around the concept of sacrificial death. Following Bandera's assassination by the KGB in 1959, the OUN(b) cult of personality around its martyred leaders was further intesified. By 1968, when the OUN(b) held its Fourth Congress they were elevated to the status of religious icons, included in prayers to "the nationalist Trinity—Konovalets, Shukhevych, Bandera."179

\section{Nationalist Myth-Making: the Intellectuals-OUN(z) and Proloh}

The Western allies generally preferred cooperation with the group around Mykola Lebed' ${ }^{180}$ The OUN(z) group, which included Volodymyr Martynets' and Volodymyr Kubijovyč, now presented themselves as democrats. ${ }^{181}$ Vasyl' Kuk, Shukhevych's successor, described Lebed' as a nondogmatic, but suspicious politician. ${ }^{182}$ From his exile in Rome, Lebed' established contact with U.S. intelligence in 1945. ${ }^{183}$ While describing him as "very radical, possibly more so than Bandera,"184 "a well-known sadist and collaborator of the Germans," 185 the CIA nevertheless realized the value of his knowledge and contact network and cultivated close relations with his group. ${ }^{186}$ During the early Cold War, extreme nationalism and fascism were retooled and employed by Western intelligence services in the struggle against the USSR. ${ }^{187}$ One CIA analyst argued that "some form of nationalist feeling continues to exist [in Ukraine] and ... there is an obligation to support it as a cold 
war weapon." 188 The CIA and the state department sponsored Lebed's 1949 immigration into the United States, and shielded him from the immigration authorities and from prosecution for war crimes until the 1990s. ${ }^{189}$ In 1956, the CIA incorporated a set of networks under Lebed's leadership as the nonprofit Proloh (Prologue) Research and Publishing Association, funded by the CIA. Through Father Ivan Hryn'okh, Proloh maintained an office in Munich, called the "Ukrainische Gesellschaft für Auslandsstudien." a significant anticommunist propaganda network: radio broadcasts, newspapers, book publishing, and the intellectual journal Suchasnist'. Its orientation was nationalist. Lebed' and his group remained very useful for the CIA for the entire Cold War. ${ }^{191}$ Hryn'okh, who after 1945 presented himself as a supporter of parliamentary democracy, was the group's associate in Western Europe. ${ }^{192}$

The collaboration between U.S. and other Western intelligence services and Lebed's group became mutually beneficial. The CIA received valuable information and insights about its Cold War adversaries in return for helping nationalist veterans into positions of influence and authority, assisting their creation of semiacademic institutions and/or academic postions at established universities. From these formal and informal networks the pronationalist scholars promoted, with some success, self-serving, apologetic accounts of the past of the OUN-UPA, and, in some cases, of their own wartime activities. The line between scholarship and diaspora politics was often blurred, as nationalist scholars combined propaganda and activism with scholarly work. Lebed's circle never condemned the crimes or the mass murders of the OUN, let alone admitted that they had taken place. On the contrary, it made denial, obfuscation, and white-washing of the wartime activities of the OUN and the UPA a central aspect of its intellectual activities.

\section{Nationalist Predominance in Ukrainian Studies}

The émigré elites maintained close bonds across the Atlantic. They developed a collective historical memory, in which the diaspora historians and chroniclers came to play a central role. The CIA employed intellectual nationalist émigrés, mainly followers of the Ukrainian National Rada and the OUN(m), at Radio Liberty or its affiliated Munich Institute for the Study of the USSR. ${ }^{193}$ Since many of its employees were elderly and had limited knowledge of western langauges, the Munich Institute never became a serious center for Soviet studies and was closed down in the seventies. ${ }^{194}$

Other nationalist activists went into academia and produced sympathetic accounts of their organizations. Among these academics were UPA veteran Petro Potichnyj; OUN veterans Evhen Shtendera, ${ }^{195}$ Wolodymyr Kosyk, ${ }^{196}$ and Taras Hunczak; ${ }^{197}$ SS-Galizien veterans Vasyl' Veryha, ${ }^{198}$ Oleksa Horbatsch, ${ }^{199}$ and Petro Savaryn. ${ }^{200}$ Some nationalist leaders-Mykola Lebed and Yaroslav Stest'ko, but also Volodymyr Kubijovyč, Roman Ilnyts'kyi, Ivan Hryn'okh, ${ }^{201}$ and Petro Mirchuk ${ }^{202}$ - produced their own accounts of the past. The latter three were linked to the Ukrainian Free University (Ukrains'kyi vil'nyi universytet, UVU) in Munich. 


\section{Ethnic Studies and Identity Politics}

Ukrainian studies was long an isolated discipline, thoroughly politicized and seen as lacking in objectivity. ${ }^{203}$ The change came with the ascent of identity politics, multiculturalism, and "ethnic" studies in the 1970s. Following the establishment of academic institutions on an "ethnic" basis, the nationalists' selective accounts of the past began appearing with established academic publishers and made inroads into the academic mainstream. From the 1970s, a new generation of nationalist academics, sympathetic to the OUN legacy, and mastering the language of political correctness, came to dominate the field of Ukrainian studies. Following the collapse of the USSR, apologetics for the OUN and UPA were increasingly articulated in terms of anti-colonialism, as the voice of the subaltern, and, in Canada, under the aegis of official multiculturalism. ${ }^{204}$ The pronationalist historians have generally failed to treat their nationalist heroes as objects of inquiry and instead used them as platforms to defend the nationalist mythologies into which they were socialized. ${ }^{205}$ Until recently, there were almost no critical studies of the Ukrainian research institutes themsleves. ${ }^{206}$

Like the Soviets, the émigré nationalists guarded their archives jealously, and their historians mirrored the Soviet toeing of the party line. ${ }^{207}$ Lebed's group controlled their archives tightly, released documents selectively, retyping, editing, or otherwise manipulating the documents to produce a selective version of the past, particularly for 1941-1942, when the OUN involvement with Nazi Germany was the most intense. ${ }^{208}$ Only with the opening of the Soviet archives could the original documents be compared with the "sanitized" versions of the diaspora publications. ${ }^{209}$ Nevertheless, many of the post-Soviet successor states have continued to release documents selectively, or have established propagandistic or ideological watchdogs to police access to documents and create a nationalistic, edifying, patriotic past. ${ }^{210}$

\section{Denial of Anti-Semitism}

Given the particular stigma anti-Semitism carried following the Holocaust, pronationalist historians have gone to great lengths to deny its very existence. Denial of the fascist and anti-Semitic nature of the OUN, its war crimes, ethnic cleansing, and participation in the Holocaust have become central components of the intellectual history of the Ukrainian diaspora. ${ }^{211}$ The UPA veteran and military historian Lev Shankovsky, claimed that antiSemitism "never existed in Ukraine. But there exists a myth about Ukrainian anti-Semitism promoted by Moscow." 212 Bohdan Osadczuk asserted that "the Ukrainian 'integral' nationalists from the OUN, unlike almost all other groupings of this type in all of Europe, did not have an anti-Semitic program." 13 "Neither the Ukrainian underground movement nor any other organizations ... cultivated anti-Semitic programs or policies," Taras Hunczak alleges.

They readily accepted Jews into their ranks and sheltered them from Nazi persecution, despite the popular perception of Jews as promoters of communism. ... In Ukraine there were no collaborationists seduced by Nazi ideology or by the seemingly irresistible Griff nach der Weltmacht (grasp for world power). Unlike the French, Belgians, Dutch, and Russians, Ukrainians did not establish 
fascist organizations and youth movements that promoted collaboration with Germany. ${ }^{214}$

Bohdan Wytwycky's entry on 'anti-Semitism' in the Encyclopedia of Ukraine, edited by Volodymyr Kubijovyč ${ }^{215}$ and published by the Canadian Institute of Ukrainian Studies, CIUS, informs us that "there has never . . . been a Ukrainian anti-Semitic organization or political party." 216

Pronationalist historians did not undertake any significant steps to interview surviving Jewish or Polish victims of the 1943-1944 ethnic cleansing. At the same time, even anti-Semitically inclined Ukrainian nationalists, such as senior OUN(b) member Petro Mirchuk, sought vindication from Ukrainian Jews to aid their cause and to absolve them of allegations of anti-Semitism. Mirchuk appealed to the Jewish community:

You should ... [be] informing Israel of the Ukrainian truth, i.e., the Ukrainian fight for liberation from the Russian tyrants. Write articles to Jewish magazines, give lectures to Israeli students about this. Dispel the malicious accusations that Ukrainians are "anti-Semites" and that they cooperated with the German Nazis - propaganda conjured up by the Russians and supported by the KGB's falsified "documents." ... Praise the heroic fight of the Ukrainian nation, of the OUN and UPA, against the German and Soviet Russian Nazis, revealing at the same time the crimes of the occupiers of Ukraine. ${ }^{217}$

Mirchuk wrote an entire book in an attempt to dispel the perception of Ukrainians as anti-Semites. A former inmate of Auschwitz, he maintained that the Ukrainians really had suffered worse than the Jews during the war, since Ukrainians, unlike the Jews would defend themselves. ${ }^{218}$ The effectiveness of the book was limited, as it is saturated with anti-Semitic, anti-Polish, and anti-Russian stereotypes and crude ethnic slurs in the OUN(b) tradition. ${ }^{219}$

Even when a Jew was choking a Ukrainian villager, sucking his blood as a nobleman's tax collector, or innkeeper, or torturing him in the basements of the Cheka, GPU, NKVD, KGB, or as a Bolshevik commissar - this was alright, honorable and just, in accordance with the command of your Jehovah. And yet when that Ukrainian defended himself, then this was already criminal "anti-Semitic" and a "pogrom of the innocent, defenseless Jews.". . . You see, the name of the Russian empire became "USSR" [SSSR in Russian] after the revolution. Are you aware of how the "goyem" within the empire read that?: "Three Sruls and one Russian." 220

Senior diaspora historians have categorically denied that the UPA murdered Jews. ${ }^{221}$ When contemporary research established, beyond any reasonable doubt, the mass killing of Jews by the OUN and the UPA, pronationalist historians deny any anti-Semitic motives behind the murders. Asked to comment on recent research findings that the UPA indeed did kill significant numbers of Jews, Professor Emeritus Petro Potichnyj's explanation was that Jews were killed because they were communists. ${ }^{22}$ The same argument is repeated in cruder form by anti-Semitic, nationalist diaspora politicians. ${ }^{223} \mathrm{~A}$ similar line of reasoning 
has been invoked to rationalize or legitimize the OUN and UPA's ethnic cleansing of Poles. Nationalist historians have defended the murder of Poles on the grounds that they supported communism and aided the Soviets, ${ }^{224}$ or they deny that the Polish victims were civilians. ${ }^{225}$ Ukrainian neofascists justify the mass murder of Poles and Jews by referring to these national minorities as "occupants" of Ukrainian lands and thus legitimate targets for mass murder. ${ }^{226}$ A crude anti-Semitic interpretation charges Mykola Lebed' with the UPA's mass murders of Poles in the summer of 1943, identifying him as a Jewish agent provocateur and citing his allegedly Ashkenazi-sounding nom de guerre "Ruban" as evidence of his Jewishness. ${ }^{227}$

Soviet propaganda complicated matters further by producing a one-sided picture of the OUN and the UPA as Nazi collaborators. ${ }^{228}$ While the Holocaust was a taboo topic in the Soviet Union, from 1979 on, Soviet propaganda used such allegations of Holocaust collaboration as a tool to discredit diaspora nationalists and to cast a shadow over the Western countries that housed them. ${ }^{229}$ The topic of collaboration and war criminality polarized Ukrainian and Jewish communities. Hypersensitive to such allegations, the Ukrainian diaspora reacted hysterically and aggressively to investigations of war criminality in their community, denying it categorically. ${ }^{230}$ Two decades after the collapse of the Soviet Union, significant sections of the Ukrainian diaspora continue to rally around alleged death camp guards, whom they regard as martyrs and victims. ${ }^{231}$ Jewish-Ukrainian relations came to constitute, in the words of Petro Potichnyj, two solitudes. ${ }^{232}$

\section{Denial of Collaboration and Fascism}

Pro-OUN historians have developed a number of strategies and narratives of denial regarding the OUN's fascism. The explicit fascist nature and orientation of the Stets'ko state project has been categorically denied, and Stets'ko's public declaration - the Akt of June 30, 1941 - was edited to omit his pledge of loyalty to Hitler and Nazi Germany. Pronationalist historians, relying on selective accounts, described this as a clean break with the Nazis. Lebed' himself claimed that the proclamation was "completely independent of all foreign influences and political and ideological orientations." ${ }^{\text {"233 }}$ Wolodymyr Kosyk insisted that "when the Germans refused to recognize the independence of Ukraine, any cooperation with them became out of the question." ${ }^{234}$ Petro Potichnyj describes the Akt as an overtly anti-German declaration. ${ }^{235}$ Taras Hunczak argues that the OUN(b) "crossed its Rubicon in the very first days of the German-Soviet war, placing it in an adversarial position vis-à-vis the Germans."236

The perhaps most intelligent denial of the OUN's fascism and collaborationism is made by a political scientist, Alexander Motyl. Motyl's argument differs from the crude denial of the OUN-affiliated historians. It is instead based upon the OUN's failure to establish a state. While Motyl admits the OUN's enthusiasm for a fascist Europe, its fascist intentions, he presents fascism is a model of organizing an existent state. This interpretation shifts the focus away from ideology to measurable achivement. Fascism, according to Motyl's interpretation, becomes primarily an issue of whether a movement is successful in achieving its goal of controlling a state. Subsequently, the argument goes, the Slovak and Croat regimes 
were fascist because they controlled states, whereas Stets'ko's unsuccessful state project did not. ${ }^{237}$ The Nazis' refusal to recognize the OUN state, Motyl argues, "inadvertently sav[ed] the nationalists from a collaborationist and possibly fascist fate." ${ }^{238}$ Motyl elegantly, and implicitly, divorces the OUN from its ideological kin — the Ustaše, the Hlinka Guard, Mussolini's Fascists, and Hitler's National Socialists. Referring to Ukrainian Nazi collaborators would be impossible twice over, according to this line of reasoning. Ukrainians, serving in German uniform, taking oaths to Adolf Hitler, and fighting for the New Order in Europe could not be called "Nazi collaborators," according to the pronationalist argument. The racist ideology of the Nazis precluded the possibility of Ukrainians joining their movement, ${ }^{239}$ "collaboration" would have required a Ukrainian state, something that did not exist in $1941 .{ }^{240}$ Motyl's argument is unconvincing for for several reasons, not least, as Daniel Ursprung has shown, because only a few fascist groups in Eastern Europe succeeded in gaining control over a state machinery. ${ }^{241}$ Motyl argues that "the correct term matters . . it's important to call things by their real names and not engage in unneccessary obfuscation." ${ }^{242}$ Yet his definitions and terminology have proved controversial among nonnationalist scholars, who have taken Motyl to task for doing exactly that. While Motyl's stringent criteria for fascism disqualifies the OUN, he defines contemporary Russia as an "unconsolidated fascist state."243 He presents himself as "a long-time critic of the Bandera movement," 244 yet his denial of the OUN's fascism and collaboration has become an important component of the narrative of diaspora nationalists and pro-OUN intellectuals. It is difficult to escape the notion that a definition of fascism which includes Medvedev's Russia, but not Bandera and Stets'ko, is tailored to fit the self-image and ideological needs of a community which to various degrees identifies with the pro-OUN tradition.

Some pro-UPA chroniclers have tried to separate the UPA from the OUN(b), arguing for the rehabilitation of the former but not the latter. ${ }^{245}$ Petro Potichnyj, in particular, eagerly emphasizes that the OUN(b) and the UPA were separate organizations and objects to the commonly used term OUN-UPA to describe the organization. ${ }^{246}$ Another strategy has been to divorce Shukhevych, Stets'ko, and Bandera from their ideology, reduce them to symbols of Ukrainian glory and heroism, and to regard the cult of personality as merely an edifying patriotic celebration. ${ }^{247}$ This line of reasoning reduces to a mere detail the significance of the OUN leaders' explicit endorsement of the Holocaust, their declarations of loyalty to Hitler and the New Europe, and the mass murder of civilians to minor stains on their records, not significantly different from similar mistakes committed by Winston Churchill and Neville Chamberlain. ${ }^{248}$

As we have seen, in the predominant diaspora discourse several key characteristics of the OUN were denied: its anti-Semitism, its ideological affinity with Nazi Germany, and its leadership's enthusiastic support for a new, fascist Europe. Yet negative definitions are an insufficient basis for myth-making and the mobilization of nationalist passions. In order to be accepted as idols, heroes the ideologues needed to supply with positive charcteristics, acceptable to democrats. Creating such heroes required more imagination from the mythmakers. Pronationalist intellectuals present the OUN(b)-controlled UPA as the source and 
basis for today's Ukrainian democracy. In order to produce such a picture, the nationalists generally curtail their scope of attention to the limited period between 1943 and 1951, relying heavily on OUN propaganda from the period when it was seeking new allies in the West. ${ }^{249}$ "By studying these primary documents of the UPA one can secure the sources of the genuinely pluralistic, democratic Ukrainian society," writes Howard Aster in a 1996 Festschrift to Petro Potichnyj. According to Aster, the documents published in Litopys UPA, of which Potichnyj is the main editor, represent the "culmination of the development of the Ukrainian nationalist ideology towards a greater emphasis on economic and social welfare, and upon securing individual rights. ${ }^{250}$

\section{Re-export of the Nationalist Myths to Ukraine}

The collapse of the Soviet Union created a demand for new history writing. Soviet textbooks were discarded and, in many cases, replaced with diaspora accounts of the past. The re-export of the nationalist narrative to Ukraine went relatively smoothly, finding a particularly receptive audience in the western parts of the country. A significant number of Ukrainian historians and intelligenty, used to toeing the Soviet line, swiftly replaced MarxistLeninist orthodoxy with nationalist interpretations. While the influence of returning émigré nationalists on Ukrainian politics has been modest, their influence on Ukrainian history writing and myth-making has been significant, particularly after $2004 .{ }^{251}$

\section{Philo-Semitic Nationalist Narratives of the OUN(b) and the UPA}

By the turn of the millennium, a new narrative about the OUN and the Jews was crystallizing, one that increasingly presented the OUN-UPA as a tolerant, ethnically inclusive force that welcomed Jews, Poles, and other minorities, and fought for a multiethnic and democratic Ukraine. ${ }^{252}$ The historian Volodymyr Serhiichuk calls the OUN-UPA a democratic force leading an antitotalitarian struggle against Stalinism and Nazism. Among the people who "sacrificed" themselves for the casue, Serhiichuk asserts, were not only Ukrainians, but also Polish and Jewish volunteers. ${ }^{253}$ Pronationalist historians often present the OUN-UPA as rescuers and benefactors who exercised an admirable restraint vis-à-vis the Jews, despite Ukrainian suffering at the hands of genocidal Jewish commissars. Some occasionally concede that there were anti-Semitic tendencies within the OUN, yet are quick to add that these were not embraced by the movement in its entirety, that it made a distinction between communist and noncommunist Jews, and ultimately adopted an inclusive view of civic nationalism, humanism, and democracy. ${ }^{254}$ Other nationalist intellectuals deny the fascist legacy entirely. Some have gone as far as to allege that the "political principles expressed in the programs of the Third Congress of the OUN(b) have today entered the Ukrainian constitution." 255

Ukrainian nationalists remember the Holocaust quite differently from Jewish survivors: "Had the OUN-UPA pursued an anti-Semitic ideology ... perhaps thousands of Jews would not have survived," wrote Taras Hunczak in response to the publication of Stets'ko's anti- 
Semitic biography, or zhyttiepys. ${ }^{256}$ In Jewish collective memory, on the contrary, Ukrainians are often remembered among the worst perpetrators of the Holocaust. ${ }^{257}$ Jewish survivors in Western Ukrane typically emphasize that with 98.5 percent of the Volhynian Jews murdered, there were few places in Europe where the Holocaust was so brutally thorough, and had it not been for the Banderites, more Jews would have survived..$^{258}$

\section{Omission and Falsification}

There is a distinction between the denial and obfuscating of the OUN's fascism and ethnic cleansing and the outright falsification of history upon the basis of forgeries. While the former constitutes the context in which this peculiar narrative developed, the representation of the OUN as philo-Semitic rescuers of Jews contains several examples of the latter. The genealogy of the narrative of the UPA as rescuers of Jews dates several decades back. One early source comes from Mykola Lebed' himself, and was published in 1946. ${ }^{259}$

The majority of physicians in the UPA were Jews, whom the UPA had rescued. ... The Jewish physicians were treated as citizens of the Ukraine and officers of the Ukrainian army. It should be duly stressed at this point that all of them discharged their existing duties faithfully. They rendered service not only to the soldiers but also to the entire population. They traveled throughout the area, and organized field hospitals and local medical stations. They did not desert the fighting ranks in trying situations, even when they had an opportunity to go over to the Reds. Many of them died a hero's death. ${ }^{260}$

In the 1950s and 1960s, a narrative of the OUN was portrayed as an organization of righteous rescuers of Jews began to crystallize, eagerly supported by the émigré OUN. ${ }^{261}$ The OUN(b) took an active role in the myth-making, including the manufacturing of forgeries. One of the more significant forgeries is the biography of Stella Krentsbakh/Kreutzbach, a fictitious Jewess, who prasies "God and the Ukrainian Insurgent Army" for having survived the Holocaust. The forged biography appeared in a volume edited by Petro Mirchuk. ${ }^{262}$ The Krenstbakh/Kreutzbach story received significant attention in the émigré press. Yet journalists who tried to find her soon learned that such a person did not exist. Philip Friedman, himself a survivor of the Holocaust from Western Ukraine, took an immediate interest in the story, but could soon conclude that "the entire story is a hoax." 263 When the nonexistent Krentsbakh/Kreutzbach could not be found, stories and rumors circulated in émigré circles that she would have been murdered, execution-style, in Israel, with a bullet to the back of her neck, for telling the truth about the UPA's attitude to the Jews. ${ }^{264}$ We will return to the ficitious Stella Krenstbakh/Kreutzbach memoirs later, as they would come to play an important role in pro-OUN propaganda half a century later.

\section{Policing the National Memory: Institutionalized Victimization}


Swept to power by the so-called Orange Revolution in 2004, Viktor Yushchenko's presidency represented the pinnacle of diaspora influence on history writing in Ukraine. It elevated the diaspora's historical myths to state policy and provided state funding to institutions tasked with the development of legitimizing narratives which the cult of the OUN leaders required. Yushchenko developed a memory politics based heavily upon a vicitimization narrative, "a meta-narrative that categorized Ukraine as a nation-victim by integrating all central historical events of the twentieth century, from the civil war and Sovietization to the Chernobyl disaster."'265 The culmination was the 1932-1933 famine, presented as the central and defining event of the Soviet period. ${ }^{266}$

Yushchenko has a complex relation to the OUN. On the one hand, he rejected its fascism, totalitarianism, terror, Führerprinzip, and ethnic cleansing. On the other hand, the Congress of Ukrainian Nationalists, the direct descendent of the OUN(b), were members of his Nasha Ukraina (Our Ukraine) Bloc. ${ }^{267}$ A somewhat paradoxical situation appeared as a new, aspiring democracy with a stated commitment to democratic values, pluralism, and human rights used state institutions to rehabilitate fascists and elevated them to national heroes, symbols of the young democracy.

The Holocaust has come to occupy a central role in contemporary European political culture, to the point that the ability to address this issue has come to be regarded as something of a litmus test of the democratic maturity of the new EU members and candidates. Increasingly, Europe imagines itself as a community of shared values, in which the Holocaust plays a key role, a "collective European memory." 268 In Ukraine, two cultures of memory, the cult of Nationalist heroes and the Western European memory culture in which the Holocaust plays a central role, are mutually exclusive. As Wilfried Jilge has aptly observed,

The absence of the Holocaust from the Ukrainian culture of memory is directly connected to the closeness of the OUN to National Socialism, particularly in its relation to anti-Bolshevism and anti-Semitism. . . . Nationalist intellectuals can legitimize the heroic role of the OUN and UPA only by ignoring the Jewish Holocaust and its connection to Ukrainian national history. ${ }^{269}$

\section{Institutionalized Production of Official Memory}

A part of Yushchenko's "Europeanization" of Ukrainian society included bringing collective memory more in line with the culture of memory of the European mainstream. In order to bridge the conflicting memories, the Yushchenko government needed to manufacture an edifying Ukrainian national past, a patriotic narrative that could partially reconcile the cult of the OUN(b) and the UPA with recognition of the Holocaust. The narratives developed by authoritarian groups in the diaspora required a significant make-over in order to make them marketable in the twenty-first century. The task rested heavily on three official institutions. The Institute of National Memory, established in 2006, was modeled after the Polish example. Its purpose was to consolidate the "nation" through a patriotic use of history. As director, Yushchenko appointed a former deputy Prime Minister, Ihor Yukhnovs'kyi, a sympathizer of the extreme right Social Nationalist Party of Ukraine. ${ }^{270}$ Another important propaganda 
institution is the Center for the Study of the Liberation Movement (Tsentr Doslidzhen' Vyzvol'noho Rukhu, TsDVR), an OUN(b) "façade structure"271 which has come to serve as an important institutional link between the young Ukrainian pro-OUN legimitizers and diaspora nationalists of the post-war wave of émigrés, such as Wolodymyr Kosyk and Petro Sodol. ${ }^{272}$ The Center is a partner of the CIUS, the Harvard Ukrainian Research Institute (HURI), as well as diaspora nationalist organizations, such as the Ukrainian Canadian Congress (UCC) and the OUN(b)-dominated Ukrainian Congress Committee of America (UCCA). ${ }^{273}$ The mission statement of the Center reads:

The history of the struggle of liberation is the basis of the national idea of every state, the basis for its values and orientation. The past of the Ukrainian people, in particular its liberation struggle, was for many years silenced and twisted by the totalitarian regimes. Therefore a new non-prejudiced view of the Ukrainian liberation movement is extraordinarily urgently needed. The $20^{\text {th }}$ century was the high point of the development of the Ukrainian resistance - the best example is the struggle of the Organization of Ukrainian Nationalists and the Ukrainian Insurgent Army from the 1920s to the 1950s. Unfortunately, today the activities of those structures remain one of the least studied parts of the Ukrainian historiography. The study of the various aspects of the struggle of the Ukrainians for their national and social freedom is the main purpose of The Center for the Study of the Ukrainian Liberation Movement. ${ }^{274}$

In turn, the Center for the Study of the Liberation Movement was linked to the Ukrainian Ministry of Foreign Affairs and, most importantly, the Ukrainian Security Forces (Sluzhba Bezpeki Ukrainy, SBU), the direct successor of the KGB. This organization was tasked with the most important aspects of Yushchenko's apparatus of memory management: to guard the memory, the institutions, resources, and archives of the Ukrainian security forces. Sofia Hrachova emphasizes that "the SBU enjoys a monopoly on information and uses this monopoly to political ends, publishing selections of documents that represent historical events according to the current official perspective, and authorizing the official position on controversial issues." ${ }^{275}$ Unlike analogue archives in other countries in East-Central Europe, most of their collections remain inaccessible to scholars.

Yushchenko's propaganda institutes disseminated an official interpretation of history to the public, based on two main themes: a victimization narrative centered on the 1932-1933 famine, which was described as a genocide against the Ukrainian nation that claimed ten million victims, combined with a glorification of the OUN(b) and UPA. The institutes were interlinked: its directors cross-referenced and legitimized each others' existence. The propagandistic and naïvely heroic representations were presented as reliable and full accounts of the past. Yukhnovs'kyi's endorsement of one of V"iatrovych's propaganda book, The Ukrainian Insurgent Army; the Army of the Undefeated is typical of this rhetoric:

The book in front of you is written by authors who belong to a new generation of Ukrainian historians, and offers a full account of the heroic struggle of the 
Ukrainian Insurgent Army. I am convinced that every Ukrainian citizen who reads it will be convinced that our people is not only good, beautiful and hard working, but also heroic. The reader will be convinced that independence came to us as a result of a long, heroic struggle. Read this book. Looking at the faces of the heroes of the UPA, you possibly also find your own likeness. ${ }^{276}$

One of the first steps taken by the Institute of National Memory was to petition Yushchenko to posthumously make the OUN(b) and UPA leader Roman Shukhevych a national hero. ${ }^{277}$ In 2007 and 2010 Shukhevych and Bandera were officially designated "Heroes of Ukraine," and a similar status was given to Yaroslav Stest'ko. ${ }^{278}$ The concept of official heroes and the habit of projecting contemporary, politically convenient values back on the past are deeply rooted Soviet practices. ${ }^{279}$ With the help of his legitimizing historians, Yushchenko attempted to divorce the OUN leaders from their fascist ideology and place them within a new, curious, philo-Semitic narrative, tailored to fit the expectations of their intended Western partners and to partly recognize the centrality of the Holocaust. This narrative denies the nationalist leaders' commitment to mass murder and ethnic cleansing and presents them as good Europeans - democrats and pluralists - and the OUN-UPA as inclusive, tolerant organizations, champions of a multi-ethnic Ukraine. Monuments to Ukrainian nationalists were erected at sites of Jewish tragedy, including former ghettoes and Babi Yar. ${ }^{280}$ Not only are these new national memorials modelled after monuments to the Holocaust of the European Jews, they are deliberately intended to surpass and forget the other "victim nation."281

\section{The OUN-UPA as Rescuer of Jews}

\section{Volodymyr V"iatrovych}

Occupying double positions as director of both the Archives of the SBU and the Center for the Study of the National Liberation Movement, Volodymyr V"iatrovych (b. 1977) was perhaps the most prominent of Yushchenko's legitimizing historians. V"iatrovych dedicated particular attention to the topic of the OUN and the Jews. ${ }^{282}$

V"iatrovych has made no effort to consult memories of Holocaust survivors who recall the OUN and UPA with terror and fear and describe the organization as deeply anti-Semitic. ${ }^{283}$ He avoids the topic of how UPA leaders were trained by Nazi Germany and collaborated in the Holocaust and ignores evidence of UPA mass murders of Jews found in Ukrainian and German archives. ${ }^{284}$ Omitting a significant body of literature, which testifies to the opposite, V"iatrovych concludes that "all-in-all, from the publications of the leading ideologues of the movement, their programmatic statements, [one can only conclude that] the ideology of the Ukrainian nationalists did not take positions that justify accusations that the OUN was anti-Semitic." ${ }^{285}$ Instead, he paints a picture of OUN neutrality to the Jews.

When I wrote a booklet on the [OUN's] relation to the Jews, a girl who worked on its graphic design aked me: I do not understand - did the nationalists love the 
Jews or did they not? For me, this was revealing. As a matter of fact, relations between nations cannot be that simple. A boy can love a girl. International relations are much more complicated. We need to explain to people the multivalence of the historical process, so that they do not go along with any sort of primitive political speculations. ${ }^{286}$

V'iatrovych highly selective accounts followed the diaspora tradition in their denial and downplaying of the OUN's anti-Semitism, and have rightly been harshly criticized as very one-sided, legitimizingm and revisionist, failing to meet even the basic scholarly requirements. In the words of John-Paul Himka,
V"iatrovych manages to exonerate the OUN of charges of antisemitism and complicity in the Holocaust only by employing a series of highly dubious procedures: rejecting sources that compromise the OUN, accepting uncritically censored sources from émigré OUN circles, failing to recognize antisemitism in OUN texts, limiting the source base to official OUN proclamations and decisions, excluding Jewish memoirs, refusing to consider contextual and comparative factors, failing to consult German document collections, and ignoring the mass of historical monographs on his subject written in the English and German languages. ${ }^{287}$

Relying primarily on the Litopys UPA, V"iatrovych attempts to deflect the OUN's anti-Semitic legacy by dwelling on five named Jews who served in the UPA, including the fictitious Stella Krentsbakh/Kreutzbach. ${ }^{288} \mathrm{He}$ indicates that the number could have been greater had the Jews shown more cooperation and cites the commander of UPA North, Ivan Lytvynchuk, who "sought a person, literate in the Yiddish language, to write an anti-German letter, addressed to the Jews," but "unfortunately, he was not able to realize this project."289 In March 2008, V"iatrovych's SBU circulated Do pochatku knyha faktiv in an effort to defend the reputation of the OUN, Shukhevych, and the Nachtigall Battalion. Distributing it through government channels, the Ukrainian Ministry of Foreign Affairs, and Ukrainian diplomatic missions abroad, the Ukrainian government presented it as an authentic chronicle from 1941 and willfully deceived the public with it. ${ }^{290}$ According to the Ukrainian government, this OUN forgery demonstrates

the OUN's categorical disagreement with the Gestapo proposition to organize Jewish pogroms.... Thus, the documents at the [Central State Archives of the Ukrainian Intellience Service, Holovnyi Derzhavnyi Arkhiv Sluzhba Bezpeky Ukrainy] HDA SBU confirm that the OUN took precautions to avoid getting involved in the actions against the Jewish population in Lviv and that there were no official orders to take part in their destruction or the execution of the pogroms. ${ }^{291}$

V"iatrovych dismisses criticism of Shukhevych as a baseless political campaign against the UPA commander's memory. ${ }^{292}$

Soviet propagandists deliberately omitted the parts of the OUN ideology and 
program which mentioned the equal rights of all national minorities; avoided giving attention to the Jews who, as members of the Ukrainian Insurgent Army, fought for an independent Ukraine. Unfortunately, that is the way many contemporary publicists and historians behave, looking in this old manner at Ukrainian history through the glasses of "Agitprop." One of the most widespread accusations against the Ukrainian nationalists is the allegation of their participation in the anti-Jewish pogroms in L'viv in the beginning of July $1941 .^{293}$

He categorically denies Shukheyvch's participation in anti-Semitic violence and condones the murder of civilians. Asked if Shukhvevych's units took part in war crimes against the civilian population, V"iatrovych retorted: "Is it possible to consider Poles or Belarusians a peaceful population, if they during the day work as ordinary villagers, only to arm themselves in the evening and attack the village?"294

In April 2008, the SBU dedicated a "public hearing" to the topic of Jews in the UPA in order to establish a new national ideology, a narrative of Ukrainians and Jews fighting together against a common Bolshevik-Muscovite enemy. The director of the SBU, Valentyn Nalyvaichenko, who presided over much of the myth-making, presented the enterprise as an attempt to dispell myths.

Today, we are making public documents about Ukrainians and Jews who fought together after the great Famine against the totalitarian and communist regimes. That historical truth has been brutally suppressed and mythologized. In a cynical and evil fashion, the KGB tried to stir up unnatural hostility between the Ukrainian and Jewish peoples. Such a myth, created and sustained over several decades, has no right to exist. ${ }^{295}$

Nalyvaichenko stated his desire to replace the Soviet lie with a Ukrainian "historical truth about the past of the Ukrainian people" and to "liberate Ukrainian history from lies and falsifications." ${ }^{296}$ The press center of the SBU asserted that "the documentary material objectively certifies that the history of the Ukrainian liberation movement provides many examples of collaboration between Ukrainians and Jews in their struggle against the totalitarian regimes. ${ }^{297} \mathrm{~V}$ "iatrovych again returned to the 1950 pamphlet Jews - Citizens of Ukraine, which he claimed represented a correct picture of the OUN's disposition toward Jews. He ignored and offered no commentary on its veiled threats. ${ }^{298}$ The legitimizing historians at the SBU had an ambivalent attitude to the Jews. Whereas they put significant efforts into presenting the Banderites as friends of Israel and Jewish nationalism, they did not shy away from traditional nationalist stereotypes. In line with its ambition to blame the 1932-1933 famine on easily definable outsiders, the SBU in July 2008 published a highly selective list of nineteen perpetrators of the "famine-genocide." Of these, eight people, or 40 percent, were of Jewish "nationality," presented in the Soviet fashion of listing the "real" Ashkenazi names next to their Slavic names ${ }^{299}$ High-profile anti-Semites and Holocaust "revisionists," among them Levko Luk"ianenko and Iurii Shukhevych, were regular guests at the events at V"iatrovych's propaganda institutes. ${ }^{300}$ 


\section{Moisei Fishbein}

One of the most successful popularizers of the nationalists' narrative, denying the UPA's anti-Jewish violence, is the poet Moisei Fishbein. Fishbein dismisses research showing that the UPA killed Jews as a "special operation" orchestrated by the Kremlin and aimed at keeping Ukraine out of NATO.

It is very important to the disinformers also to discredit General Shukhevych, the UPA, and the entire Ukrainian national liberation movement, as well as President Yushchenko of Ukraine. Therefore they used the old Chekist provocation and played "the Jewish card": one was the accusation [that the UPA] murdered Jews, the other the "heroization" of the alleged murderers. The purpose is clear: to exclude Jews from the Ukrainian national renaissance. To alienate the entire civilized world, from those who want the rebirth of a true, Ukrainian Ukraine - Ukrainian in spirit, in language, in memory about her geniuses and heroes. Ukrainian - for who live there, regardless of their ethnic origin.... [The claims of] "UPA Anti-Jewish actions" is a provocation, distributed from Moscow. It is a provocation. That the UPA would have killed Jews is a lie. Tell me, how could the UPA have exterminated Jews when there were Jews in the UPA, who served in the UPA? I knew Jews who served in the UPA. For instance, I knew doctor Abraham Shtertser, who lived in Israel after the war. There was Samuel Neuman, his pseudonym was Maksimovich; there was Shai Varma (pseudonym Skripach); there was Roman Vynnytskyi, his pseudonym was Sam. There was an outstanding figure in the UPA, a woman called Stella Krentsbakh; she later used a pseudonym. She was born in Bolekhov in the L'viv area, she was the daughter of a rabbi, Zionist, and was friends there, in Bolekhov, with the daugher of a Greek Catholic priest, called Olya. In 1939 Stella Krentsbakh graduated from the philosophical department of L'viv University. From 1943 she was a nurse and intelligence officer in the UPA. In the spring of 1945 the NKVD captured her during a meeting with a contact in Rozhniatov. Thereafter she was jailed, sentenced to death, but UPA soldiers liberated Stella Krenstbakh, the Jewess. In the summer of 1945 she crossed the Carpathians with Ukrainian insurgents and October 1, 1946, she managed to reach the English zone of occupation in Austria. She made it to Israel. Do you know where she worked in Israel? In the Ministry of Foreign Affairs. In her memoirs Stella Krentsbakh wrote: "The reason I am alive today, and have been able to give all the strength of my 38 years to the free Israel, I owe, apparently to God and the Ukrainian Insurgent Army. I became a member of the heroic UPA on November 7, 1943. In our group I counted 12 Jews, of which eight were physicians. ${ }^{\prime 301}$

Repeating this claim in a number of forums, Fishbein reduces the OUN's anti-Semitism to a fabrication invented by the enemies of Ukraine. "In playing the 'Jewish card' in their special operations against Ukraine, the Russian special services are exploiting the 'PutinJuden,' particularly Moscow-based rabbis," Fishbein wrote. ${ }^{302}$ He repeated this argument at a conference at the University of Illinois at Urbana-Champaign in $2009 .{ }^{303}$ His words were enthusiastically reported in the nationalist press. The English-language Kyiv Post, a popular 
forum for the diaspora, published his statement as an op-ed. ${ }^{304}$ Fishbein received remarkable media attention, not only in nationalist diaspora publications such as The Ukrainian Weekly, Ukrainian News, Kyiv Post, and others, but also in mainstream news venues, such as the $\mathrm{BBC}$ news. Respectable analysts, like Paul Goble uncritically repeated Fishbein's assertions:

Few people have been as dogged as Fishbein in tracking down this and other Russian falsifications and slanders against Ukraine, but his work in this area deserves to be better known not only because it ... explains why so many Ukrainians want to gain the protection of Western institutions like NATO. ${ }^{305}$

With state support, Fishbein recirculated Mirchuk's ficticious Krentsbakh/Kreutzbach "autobiography," accompanied by an English translation, I Am Alive Thanks to the $U P A$ presenting it as an authentic document which would once and for all disprove the OUN-UPA's anti-Semitism. ${ }^{306}$ Soon thereafter, V"iatrovych's Center for the Study of the Liberation Movement again returned to the Krentsbakh/Kreutsbach story, issuing a press release with the title "The Jewess Stella Krentsbakh explained that she survived thanks to UPA." ${ }^{307}$ Marco Levytsky, editor of the pro-OUN Ukrainian News in Edmonton, Alberta, again and again returned to the Stella Krentsbakh/Kreutzbach story, citing the poet as a reputable source and authority in the field, using the story to deny OUN complicity in the Holocaust. ${ }^{308}$ Similarly, Victor Rud, the chairman of the Foreign Affairs and Human Rights' Committee of the Ukrainian American Bar Association, in an open letter to the Washington Post in response to an article critical of Yushchenko's UPA cult, relies on Fishbein's lecture at Urbana-Champaign, referring to it as "a recent study" and citing Fishbein's statement to the effect that

Russia's special services are seeking to destabilize the situation in Ukraine, undermine its sovereignty and independence, create a negative image of this country, block its integration into European and Euro-Atlantic structures, and turn Ukraine into a dependent and manipulated satellite. In their special operations against Ukraine they attribute exceptional importance to the 'Jewish card. ${ }^{309}$

In December 2009, Fishbein again circulated the 1950 UPA pamphlet Jews-Citizens of Ukraine in another attempt at disproving UPA anti-Semitism. Fishbein offered no comment on its ethnonationalist statements that Jews are but guests in the land of Ukrainians, its stereotyping of Jews as Bolsheviks, and was unconcerned even by its thinly veiled threats. ${ }^{310}$ One can only speculate about Fishbein's motives for publishing this known forgery. It seems unlikely that he, or the legitmizing historians, are unaware of the literature on the topic, including in the Ukrainian language; as late as 2008 the historians Taras Kurylo and John-Paul Himka discussed the Krentsbakh/Kreutzbach forgery in the leading intellectual journal Ukraina Moderna. ${ }^{311}$

\section{Myth-Making with Complications}


Despite the pretentious claims of the propagandists, it is not fully clear what can be made of the activities of a handful of Jewish physicians in the UPA. Even if we were to take the most optimistic assessments of the legitimizing historians, include the forgeries and accept at face value their assertions regarding the Jewish identity of all the unnamed people V"iatrovych claims fought in the OUN and UPA, the number of Jews in those organizations still constitute a minute fraction of the total UPA membership (between 0.001 and 0.1 percent). ${ }^{312}$ Certainly it is difficult to interpret a handful of Jewish nurses and doctors who survived the Holocaust within the ranks of the UPA as evidence of the existence of a joint OUN-UPA-Jewish front against common enemies. V"iatrovych does not comment upon the many documented cases of how the OUN-UPA attacked and murdered rescuers of Jews. ${ }^{313}$ He omits the fact that 50 percent of the UPA leaders had a background as collaborators within the military, police, or punitive organs of the Nazi German occupants and played key roles in the implementation of the Holocaust in the occupied Soviet Union.

Nevertheless, this enchanted narrative has found a receptive audience beyond the circle of the nationalist true believers and started to take on a life of its own. The legend of the UPA as an inclusive, democratic force where Jews fought side by side with the OUN against Hitler is already making it into popular culture. In 2010, Oksana Zabuzhko, perhaps Ukraine's most popular fiction writer, published a massive book, Muzei pokynutykh sekretiv, (The Museum of Forgotten Secrets) in which the major heroine is a Jewish nurse in the UPA, apparently modeled on Krentsbakh/Kreutzbach. For her research, Zabuzhko relied partly on material provided to her by the Center for the Study of the Liberation Movement and its museum in the former Lontskyi Prison, where on the request of V"iatrovych center, the book launch was held. ${ }^{314}$ The first edition sold out in three days. Reviewers received the book very well. "Oksana Zabuzhko has written a panorama of the history of the Ukrainian past - the history of Ukrainians of the $20^{\text {th }}$ century," the Lviv daily, Vysokyi Zamok, commented. ${ }^{315}$

Nevertheless, government propaganda has failed to gain popularity with ordinary Ukrainians. An nationwide opinion poll conducted by the Kyiv International Institute of Sociology in June 2009 showed that only a small minority of Ukrainians embraced Yushchenko and his myths about the OUN and UPA. ${ }^{316}$ The cult of the OUN and UPA has, however, tainted the image of Ukraine abroad, particularly in Poland, a key EU partner. Polish collective memory of Ukrainians during World War II remains highly critical, according to an August 2009 survey, even more so than the wartime roles of Germans and Russians. ${ }^{317}$ By turning Bandera, Shukhevych, the OUN(b), and the UPA into official heroes and denying their murders, Yushchenko's legitimizing historians helped cement a stereotypical identification of Ukrainians with banderivtsy (Banderites). Many Poles hold "Ukrainians" collectively responsible for the crimes of the UPA. ${ }^{318}$ Ironically, some of the historical interpretations of his successor Viktor Yanukovych and his electorate in the east and south of the country are more in line with the rest of Europe than those Yushchenko, who describes his political orientation as oriented toward the West. ${ }^{319}$

\section{Conclusion: Politics, Memory and Raison d'être}


Nationalizing states are often involved in the manufacturing of national myths, and the Ukrainian case is by no means unique. Here, in a new, weak state, divided by language, religion, and historical experience, the leadership has put significant effort into producing historical myths of political utility, a significant part of which stand in direct opposition to what the sources and current scholarship say. Ernst Renan wrote, "Forgetting, I would even go so far as to say historical error, is a crucial factor in the creation of states. ${ }^{\prime \prime 20}$ Bruno Bettelheim famously argued that "children need fairytales." "We want our children to believe that, inherently, all men are good. ... The dominant culture wishes to pretend, particularly where children are concerned, that the dark side of man does not exist, and professes a belief in an optimistic meliorism." ${ }^{321} \mathrm{He}$ argues that fairy tales contribute to the child's psychological development.

Ambiguities must wait until a relatively firm personality has been established on the basis of positive indentifications. ... Futhermore, a child's choices are based, not so much on right versus wrong, as on who arouses his sympathy and who his anthipathy. The more simple and straightforward a good character, the easier it is for a child to identify with it and to reject the bad other. ${ }^{322}$

In their famous study, Opa war kein Nazi (Grandpa was no Nazi), Harald Welzer, Sabine Moller, and Karoline Tschuggnall highlight the difficulties many Germans have in relating to their family members' role in the Third Reich. Generations raised and socialized in the Federal Republic, well aware of the crimes of Nazi Germany, tend to see the Nazis as "the others" and to disavow their own grandparents' association with National Socialism. The authors demonstrate that there "is no systematic place for the Holocaust in German family memories" 323 and that "the following generations construct a past in which their relatives appear in a role having nothing to do with the crimes. ${ }^{" 324}$ The parallels to the Ukrainian diaspora memory of the OUN and the Holocaust are striking. The diaspora culture of memory, developed primarily in North America and re-exported to Ukraine after 1991, denies not only the OUN's fascism and anti-Semitism, it denies the crimes themselves, presenting perpetrators as rescuers of Jews. Fact-based historical analysis is rejected and replaced by comfortable and politically expedient myths of the past. Weltzer, Moller, and Tschuggnall's observation, that the "emotional process of memory reproduction is not the same thing as learning from facts and possessing of knowledge," pertains also to the Ukrainian diaspora ideologues and Yushchenko's legitimizing historians. ${ }^{325}$

There are two interrelated groups of myth-makers. The first group consists of the immediate heirs to the fascists: authoritarian nationalists and neofascists who share the tenets of the OUN philosophy - authoritarianism, leader cult, and anti-Semitism. Ironically, the philoSemitic legitimizing narrative originated within this group as a byproduct of its concerted efforts to cover up the OUN and UPA's anti-Jewish violence and to obfuscate the organization's fascist activities. The second group consists of politicians, propagandists, and pundits who describe themselves as democrats yet identify with and celebrate the OUN, typically defending its fascist activities while denying its fascism. Both groups pick and choose the 
parts of the legacy they find convenient. They gloss over, downplay, deny, or legitmize the OUN-UPA mass murders. Under Yushchenko, this philo-Semitic nationalist narrative was elevated to official policy and the myth-making given state funding. While the ideology of these two groups differ, they often work in tandem, the activities of the former paving the way for the latter. Both groups are apologists for a fascist tradition. Neither one has admitted the OUN's war crimes, let alone condemned them.

Whereas the myths surrounding the OUN-UPA are products of diaspora imagination, they were disseminated by successors of the Ukrainian KGB. The inspiration for Yushchenko's establishment of an Institute of National Memory comes from contemporary Poland, but his institutes of myth-production and memory management closely resemble old Soviet propaganda organs. The fairy tale scenarios produced by the state agencies come, paradoxically, with claims to truth and objectivity. Herein lies a paradox of the myth-making: the selective, propagandistic, and edifyingly patriotic myths are presented not as such, but, on the contrary, as a more "true" and "correct" version of Ukrainian history. ${ }^{326}$ The dissemination of misleading propaganda - even forgeries - in the name of "historical truth" and "objectivity" reveal Soviet habits and practices, and mirror Stalin's 1931 commentary that what matters in history writing is not the sources, but rather a "correct attitude." ${ }^{27}$ The Soviet nature of these clumsy hagiographies and simplistic myths is reflected not only in their Manichean simplicity, their blind spots, omissions, and taboos, ${ }^{328}$ but also in Yushchenko's attempts to accompany his myth-making with the legal repression of those who question the official line..$^{329}$

Is the manifacturing of contrafactual nationalist legends and edifying patriotic myths necessarily a bad thing? Bettelheim points to some of their benefits of legends and fairy tales. Some diaspora nationalists reason along similar lines. Commenting on the Krentsbakh/ Kreutzbach forgery, historian and UCC activist Roman Serbyn argues that "there is nothing wrong with the idea of a Jewish woman serving in the UPA; as part of Ukrainian mythology it promotes positive Ukrainian-Jewish relations." Serbyn's problem is rather that the rehabilitation of Ukrainian forces in service of the Nazis was not far-reaching enough: "What Yushchenko can be reproached with is not having brought into the project the Ukrainian veterans of the Waffen SS Division Halychyna [Galizien, PR] and other units of the armed forces of the Axis forces." 330

Yet, simplistic heroic tales based upon myths, half-truths, and deliberate falsifications have not only resulted in a failure to examine the past. What is worse, distorted, even fictional, narratives are presented as "truth" and scholarly inquiry is derided as enemy propaganda, critical voices are labeled as communists, "Ukrainophobes," Putin supporters, or "useful idiots" in the service of Yanukovych and the Kremlin. ${ }^{331}$ This logic implies that Ukraine would benefit more from silence, state propaganda, and mythmaking than from critical inquiry. Furthermore, the philo-Semitic narrative of the OUN and UPA constitutes a form of Holocaust "revisionism"-it denies the OUN-UPA's involvement in the Holocaust and divorces it from its fascist and anti-Semitic legacy by means of producing an unrepresentative and factually incorrect version of the organization's past. It shares with other forms of 
Holocaust denial the gross exaggeration of relatively insignificant details while it ignores, overlooks, or presents well-documented facts as falsifications. By legitimizing the myths of the extreme right, this narrative has aided the mobilization of the Ukrainian extreme right.

These myths failed to constitute a basis for national mobilization outside the diaspora and the Ukrainian west. On the contrary, the cult of the OUN-UPA has polarized Ukraine and antagonized its neighbors. The deliberate distortions have complicated the process of historical and political reconciliation among Ukrainians, Jews, and Poles. It has frustrated Poland and the EU and unneccesarily complicated Ukrainian integration into European institutions. Last, but not least, it made it easier for the Kremlin to portray the Ukrainian leadership as irresponsible and politically immature, and to exploit this for political purposes.

Whereas children - and nationalist politicians - may need fairy tales, the task of the historian is to deconstruct and understand the past. Awareness of the Holocaust, attempts at understanding the mechanisms behind the OUN and UPA's racist violence, and respect for their victims does not have to be an obstacle to nation-building. On the contrary, an open inquiry of the past is an important component of the building of a liberal democratic society with rule of law, pluralism, and respect for human rights.

\section{Postscript, October 2010-May 2011}

Since this article was written in the fall of 2009, Ukraine has seen a change of government. As one of his final acts in office, Yushchenko officially designated Stepan Bandera as a Hero of Ukraine, in a polarizing and much-criticized move. The Ukrainian Canadian Congress, of which both OUN wings and veteran organizations of the UPA and the WaffenSS Galizien are members, enthusiastically endorsed Yushchenko's decree and called "upon the Government of Canada to make changes to Canada's War Veterans Allowance Act by expanding eligibility to include designated resistance groups such as OUN-UPA." ${ }^{332}$ Under Yanukovych, a sharp reversal in the field of memory management followed. Yushchenko's posthumous designation of Bandera and Shukhevych as national heroes was declared illegal by the courts, and the order was recalled. ${ }^{333} \mathrm{~V}$ "iatrovych and Yukhnovs'kyi were fired, and the SBU Archives and the Institute of National Memory got new directors. Valerii Soldatenko, who succeeded Yukhnovs'kyi as director of the Institute of National Memory, is a member of the Communist Party. In March 2011, it was announced the institute was to be closed down. ${ }^{334}$

The end of state support for the OUN and UPA cult outraged nationalist believers in the diaspora. Representatives of the OUN(b)-controlled Ukrainian Congress Committee of America (UCCA) refused to meet with President Yanukovych and staged noisy protests during his visit to the United Nations in New York in September 2010. Askold Lozynskyj, 335 the former President of the World Congress of Free Ukrainians who helped organize protest, told the Ukrainian ambassador to the United States that the only thing that could prevent the protests would be to "fire Soldatenko, Education Minister Dmytro Tabachnyk and recognize the Holodomor [Famine] as genocide." ${ }^{336}$ Dressed in a folkloristic outfit and with a bulls' horn in his hand, Lozynskyj led noisy demonstrations outside the UN General 
Assembly, chanting "Russian butchers, go to hell!" "Slava Ukrainy! Heroiam Slava!"337 The diaspora OUN(b) regard the popularly elected Yanukovych government as an "occupation regime" with which they have broken off all contact. ${ }^{338}$ Anti-Semitism is a central component in Lozynskyj's apologetics. He claims that "an . . overwhelming amount of Soviet accomplices during the Soviet's two years in Western Ukraine from 1939-1941 were Jews, ${ }^{339}$ alleges Jewish control over Canadian media, ${ }^{340}$ and charges that scholars who study the anti-Jewish violence of the OUN and UPA are paid to "invent demons" by Jewish interests. ${ }^{341} \mathrm{He}$ dismisses scholarly studies of the OUN's racism with references to the alleged Jewish ethnicity of the researchers. ${ }^{342}$

Paul Grod, president of the Ukrainian Canadian Congress has favored quiet diplomacy, ${ }^{343}$ but remains as committed as ever to the cult of the OUN and the UPA, vehemently and categorically denying Ukrainian nationalist involvement in the Holocaust. ${ }^{344}$ In March, 2010 the UCC organized a "task force" of nationalist activists to prevent "attacks on the national liberation movement" by silencing, discrediting, or undermining the credentials of critical scholars, and accusing them of "treason" against their imagined communities. ${ }^{345} \mathrm{After}$ he lost his job as director of the SBU archives, in 2010, V"iatrovych has been engaged by his nationalist "partners" in the diaspora. He received a fellowship at the Harvard Ukrainian Research Institute and was invited as keynote speaker at the twenty-third conference of the Ukrainian Canadian Congress as in Edmonton on November 5-7, 2010. ${ }^{346}$ The CIUS invited V"iatrovych to speak at the University of Alberta. In Edmonton, he again denied the OUN's anti-Semtism and obfuscated its involvement in the Holocaust. The Lviv pogrom, he argued, was the subject of "much academic controversy."

Individual members of the population did take (part) in the German-initiated repressions.... The participation in the repressions from the general population included criminal elements who wanted to benefit materially by participating in the repressions. Some took part relying on German propaganda, which was put forward at the time that Jews were responsible for, as the Germans called it, Jewish Bolshevism." But "no Ukrainian political movement advocated the participation in these repressions or anti-Jewish pogroms," he said. "The fact that some members of the police force organized by the Germans ultimately ended up in various military formations, such as the ... Ukrainian Insurgent Army (the military wing of the Organization of Ukrainian Nationalists) does not establish proof that these particular formations were involved in perpetrating the Holocaust." ${ }^{347}$

Introduced as "the Ukrainian historian Volodymyr V"iatrovych at Harvard University," in Ukrainian media, he again dismissed OUN's anti-Semitism involvement in the Holocaust as "a historical myth." 348

On Rememberance Day, a day which in Canada traditionally emphasizes the role of military men in the fight against fascism, the UCC saluted the OUN, the UPA, and the Ukrainian veterans of Waffen-SS Galizien. ${ }^{349}$ Less than a week later it pledged genocide 
awareness for the 1932-1933 famine, inflating the number of victims by 300 percent, to over ten million people..$^{350}$

Abandoned as state policy following Yushchenko's disastrous defeat, the narrative of denial and myth making around the OUN-UPA is now again mostly the preserve of the extreme right in the diaspora and Ukraine proper. ${ }^{351}$ Yanukovych has continued Yushchenko's legacy of playing the eastern and western parts of Ukraine against each other, further polarizing the pro-nationalist and "anti-Orange" camps.

The right-wing extremist Svoboda party has become the largest party in the local elections in Western Ukraine and the fifth largest party nationwide. While its political breakthrough came under Yanukovych, the responsibility must be shared by Yushchenko and his legitimizing historians, whose official veneration, state-sponsored myth making and denial of the OUN-UPA atrocities provided political legitimacy and paved the way for this second turn to the right.

The ultra-nationalist rendering of history has devolved into historical fiction. Dedicated fascists and anti-Semites who repeatedly volunteered their services for Hitler's new Europe are presented as the first to oppose the Nazis, totalitarians are presented as freedom fighters. Accounts in the press, polemics, and popular culture allege that "Bandera was the only warror [lytsar] in Europe, who in 1941 said "no' to Hitler." 352 In Svoboda party leader Oleh Tiahnybok's interpretation of history,

our Heroes were shaped in bloody battle with the occupants when the so-called 'civilized Europe' ran away. Therefore, to judge Bandera is to spit in the face of the Ukrainian national-liberation movement. Anti-colonial to its nature, it was first and foremost anti-communist and anti-Nazi. [To condemn Bandera] means spitting on the Ukrainians' right to their own state. ${ }^{353}$

We have thus come full circle. Over the years, crossing the Atlantic back and forth, the self-serving nationalist mythology has taken increasingly fantastic forms. Stets'ko's openly pro-fascist, pro-Hitler, pro-German declaration has metamorphosed not only into an anti-Nazi act, but into the first and and bravest challenge to Hitler in Europe. The OUN leaders' anti-Semitism and open endorsement of the Holocaust are dismissed with reference to a handful of Jewish survivors within the ranks of UPA. As an ultimate irony, this narrative is appropriated by extreme nationalists who do not shy away from anti-Semitic historical interpretations and open admiration for the Waffen-SS. 


\section{Notes}

* A version of this paper was presented at the forty-first national convention of the American Association for the Advancement of Slavic Studies in Boston, Massachussets, November 12-15, 2009.

\section{Acknowledgements}

This article has benefited from the comments, insights, ideas and constructive criticism of Marco Carynnyk, Tomislav Dulić, Norman J. W. Goda, John-Paul Himka, Krzysztof Janiga, David Marples, Nina Paulovicova, Grzegorz Rossoliński-Liebe, and the extensive and very helpful comments of two anonymous reviewers. The author also wishes to acknowledge the generous support from the Interdisciplinary Research Training Group 1540 "Baltic Borderlands: Shifting Boundaries of Mind and Culture in the Borderlands of the Baltic Sea Region," funded by the German Research Foundation (DFG).

1. See, for instance, David R. Marples, Heroes and Villains: Creating National History in Contemporary Ukraine (Budapest: Central European University Press, 2007); Johan Dietsch, Making Sense of Suffering: Holocaust and Holodomor in Ukrainian Historical Culture (Lund: Lund University Press, 2006); Olena Radziwiłł, "Viina za viinu: Druha svitova viina ta Velyka vitchyzniana viina u shkil'nykh pidruchnykakh z istorii Ukrainy (1969-2007)," paper presented at "World War II and the (Re)Creation of Historical Memory in Contemporary Ukraine, An International Conference," Kyiv, Ukraine, September 24, 2009.

2. On this topic, see Franziska Bruder's pioneering study, "Den ukrainischen Staat erkämpfen oder sterben!': Die Organisation Ukrainischer Nationalisten (OUN), 1928-1948 (Berlin: Metropol Verlag, 2007), 23.

3. Armstrong writes that "the theory and the teachings of the nationalists were very close to fascism, and in some respects, such as the insistence on 'racial purity,' even went beyond the original fascist doctrines.” John A. Armstrong, Ukrainian Nationalism, 1939-1945 (New York: Columbia University Press, 1955), 279. "At least as a start, it seems preferable not to call the OUN's ideology 'fascism' but to designate it 'integral nationalism,' in accordance with Carlton Hayes' classification of the Action Française model." John A. Armstrong, "Collaborationism in World War II: The Integral Nationalist Variant in Eastern Europe,” Journal of Modern History, 40, no. 3 (Sep. 1968): 400-401.

4. Juan J. Linz, "Political Space and Fascism as Late-Comer: Conditions Conductive to the Success or Failure of Fascism as a Mass Movement in Inter-War Europe," in Stein Ugelvik Larsen, Bernt Hagtvet, and Jan Petter Myklebust (eds.), Who Were the Fascists: Social Roots of European Fascism (Oslo: Universitetsforlaget, 1980): 169, 187.

5. Grzegorz Rossoliński-Liebe, “The 'Ukrainian National Revolution' of 1941: Discourse and Practice of a Fascist Movement," Kritika: Explorations in Russian and Eurasian History 12, no. 1 (Winter 2011): 87, n. 12. Heorhii Kas'ianov rejects attempts at establishing an umbrella definition of the far right, arguing that applying terms such as fascism, Nazism, but also integral nationalism to the OUN is not productive, as these movements constitute different phenomena. Teoriia natsii ta natsionalizmu (Kyiv: Lebed', 1999), 326.

6. Bruder, "Den ukrainischen Staat," 32; Oleksandr Panchenko, Mykola Lebed': Zhyttia. Diyal'nist'. Derzhavno-pravovi pohliady (Lokhvytsia: Kobeliaky, 2001), 15; Anatol'Kamins'kyi, Krai, emihratsiia i mizhnarodni zakulisy (Manchester: Vydannia Politychnoi Rady OUNz Nakladom Kraevoi PR OUNz u Velykobrytanii, 1982), 39-42. 
7. Bruder, “Den ukrainischen Staat,” 35.

8. Roger Griffin, Modernism and Fascism: The Sense of a Beginning under Mussolini and Hitler (Basingstoke: Palgrave Macmillan, 2007), 62.

9. There is a rich literature on the theory, definition, and charcterization of fascism. Here it would suffice to mention Roger Griffin, The Nature of Fascism (London: Pinter, 1991), 1-19, and Stanley G. Payne, A History of Fascism, 1914-1945 (Madison: The University of Wisconsin Press, 1995), 3-52, and idem, "The Concept of Fascism," in Ugelvik Larsen, Hagtvet, and Myklebust, Who Were the Fascists, 17. On the fascism of the OUN, see Rossoliński-Liebe, "The "Ukrainian National Revolution' of 1941," 85-90.

10. Bruder, "Den ukrainischen Staat," 51 . The characterization of the OUN as fascist is also shared by Richard Breitman, Norman J. W. Goda, John-Paul Himka, David Marples, Grzegorz Rossoliński-Liebe, Timothy Snyder, and other historians. See Richard Breitman and Norman J. W. Goda, Hitler's Shadow: Nazi War Criminals, U.S. Intelligence, and the Cold War (Washington, D.C.: The National Archives, 2010), 74, and, for instance Himka, Marples, Rossoliński-Liebe, and Snyder in Tarik Cyril Amar, Ivan Balyns'kyi, and Yaroslav Hrytsak (eds.) Strasti za Banderoiu: statti ta essei (Kyiv: Hrani-T, 2010).

11. Taras Kuzio, "OUN v Ukraine, Dmytro Dontsov i zakordonna chastyna OUN," Suchasnist, vol. 12 (1992): 34; Armstrong, "Collaborationism in World War II," 402.

12. Taras Kurylo, "The Jewish Question' in the Ukrainian Nationalist Discourse of the Interwar Period," Polin, no. 26 (forthcoming).

13. Iaroslav Orshan, "Doba natsionalizmu," V Avanhardi (Al'manakh) (Paris: n.p. 1938), 41. Availble online from the web forum Natsional'na Diia "RID," http://rid.org.ua. Thanks to Taras Kurylo for this reference.

14. Yury Boshyk, ed., World War II in Ukraine: History and Its Aftermath (Edmonton: CIUS and University of Alberta, 1986), 172-173; "10 zapovidei Ukraintsia-Natsionalista (Dekal'oh)," Tsentral'nyi derzhavnyi arkhiv hromas'kykh orhanizatsii Ukrainy, henceforth TsDAHO Ukrainy, f. 1, op. 23, d. 931, ark. 68. Thanks to John-Paul Himka for this reference.

15. Mykola Posivnych, 'Molodist' Stepana Bandery," in Mykola Posivnych (ed.), Zhyttia i diial'nist' Stepana Bandery: Dokumenty i materialy (Ternopil': Aston, 2008), 38.

16. Z Tvoei rodyny stvory kyvot chystoty Tvoei Rasy i Natsii, from 44 pravyla zhyttia ukrains'koho natsionalista. Sviatoslav Lypovets'kyi, OUN banderivtsi: frahmenty diial'nosti ta borot'by/The Organization of Ukrainian Nationalists (Banderites): A Collage of Deeds and Struggles (Kiev: Ukrains'ka Vydavnycha Spilka, 2010), 93-94.

17. Nationalist publishers translated Nazi racial theoretician Hans Günther's 1920 racist tract Ritter, Tod und Teufel as Hans F. K. [Ginter] Günter, Lytsar, Smert'i chort': Herois 'ka mysl'. Vstup ta pereklad iz IV. nimets'koho vydannia Rostyslava Iendyka [Introduction and translation from the IV German edition by Rostyslav Iendyk] (L'viv: Vydavnytstvo "Prometei," 1937). Orshan introduced the book, written "in 1920, at the time of all the misery that befell Germany after its loss in the World War, democratic-liberal decay, pacifism, and the weakening of the national instinct, and the rise of Jewish supremacy [postupaiuchoi supermatii zhydivstva]," Orshan, Doba Natsionalizmu, 3-4. On Hans F. K. Günther, see Alan E. Steinweis, Studying the Jew: Scholarly Anti-Semitism in Nazi Germany (Cambridge, Mass.: Harvard University Press, 2006), 25-41, and Leo Kramár, Rasismens ideologer: Från Gobeneau till Hitler (Stockholm: Norstedts Förlag, 2000), 207-227. 


\section{Orshan, Doba Natsionalizmu, 5.}

19. Mykola Mikhnovs'kyi's Decalogue was a set of rules to police the political, social, and sexual activities of nationalists. Rule 1 stated that a Ukrainian state should reach from the Carpatians to the Caucasus, number 2 that "all people are your brothers, but Muscovites, Poles, Hungarians, Romanians and Jews are the enemies of your people [moskali, liakhy, uhry, rumuny ta zhydy-se vorohy nashoho narodu]. Rule 3 states "Ukraine for the Ukrainians!" Rule 10, which so appealed to Sukhovers'kyi and other nationalist activists, reads: "Do not take a wife of alien stock, since your children will become your enemies; do not find aquaintances among the enemies of our people, as that would give them strength and courage; do not buy from our oppressors as that will make you a traitor." This nationalist decalogue is still on the Ukrainian Students' Association - University of Winnipeg (UWUSA) Facebook site: http://www.facebook.com/group.php?gid=171502843414 (accessed March 3, 2011).

20. Mykola Sukhovers'kyi, Moi spohady (Kyiv: Vydavnytstvo “Smoloskyp,” 1997), 50. Sukhovers'kyi (1913-2008), a native of Bukovyna, worked in Berlin as a liason between the OUN(m) and Nazi Germany during World War II and later settled in Canada. He was the honorary president of the Ukrainian War Veterans association in Edmonton and a leading figure in the OUN(m). He worked as a librarian at the University of Alberta where the Canadian Institute of Ukrainian Studies at the University of Alberta still administers the Celestin and Irena Suchowersky Endowment Funds. Bohdan Klid and Myroslav Yurkevych, CIUS: 30 Years of Excellence/KIUS: 30 Rokiv Uspikhiv, 1976-2006 (Edmonton: Canadian Institute of Ukrainian Studies at the University of Alberta, 2006), 35.

21. “Orhanizatsiia Ukrains'kykh Natsionalistiv: Natsiia iak spetsies,” Holovnyi Derzhavnyi Arkhiv Sluzhby Bezpeky Ukrainy (henceforth HDA SBU), f. 13, no. 376, tom 6, 1. 1. Undated OUN brochure, no earlier than 1943.

22. "Orhanizatsiia Ukrains'kykh Natsionalistiv: Rodyna v systemi orhanizavanoho ukrains'koho natsionalizmu," HDA SBU, f. 13, tom 6, 1. 6.

23. Ibid., f. 13 , no. 376 , tom $6,1.7$.

24. "Orhanizatsiia Ukrains'kykh Natsionalistiv: Atomistychna teoriia pro natsiu," HDA SBU, Fond 13 , no. 376 , tom $6,1.4$.

25. Rozbudova Natsii, no. 11-12 (Nov.-Dec. 1930): 265-266, cited by Krzysztof Łada, "Teoria i ludobójcza praktyka ukraińskiego integralnego nacjonaliymu wobec Polaków, Żydów i Rosjan w pierwszej połowie XX wieku," in Cz. Partacz, B. Polak, and W. Handke, eds., Wotyń i Małopolska Wschodnia 1943-1944 (Koszalin-Leszno: Instytut im. gen. Stefana Gorta, 2004), 48.

26. “Z programu szkolenia bojówek OUN z 1935 r.," Derzhavnyi Arkhiv Rivnenskoii Oblasti (DARO), f. 32, op. 36, spr. 2, 1. 22 ff. Cited by Ewa Siemaszko, "Przemiany relacji polsko-ukraińskich od połowy lat trzydziestych do II wojny światowej," Biuletyn instytutu pamięci narodowej, no. 7-8 (116-117) (July-August 2010): 65, and reprinted in Wiktor Poliszczuk, Nacjonalizm ukraiński w dokumentach (czesść 2): Integralny nacjonalizm ukrainski jako odmiana faszyzmu. Tom czwarty. Dokumenty z zakresu działań struktur nacjonaliymu ukraińskiego w okresie od 1920 do grudnia 1943 roku (Toronto: Viktor Poliszczuk, 2002), 49.

27. On the OUN's anti-Semitism, see Marco Carynnyk, "Foes of Our Rebirth: Ukrainian Nationalist Discussions about Jews, 1929-1947," Nationalities Papers, Vol. 39, No. 3, (May 2011): 315-352; Bruder, "Den Ukrainischen Staat,", 46-48, 99-101, 166-169; Kurylo, "Jewish Question"; Taras Kurylo and John-Paul Himka [Ivan Khymka], "Iak OUN stavylasia do ievreiv? Rozdumy nad knyzhkoiu Volodymyra V"iatrovycha Stavlennia OUN do ievreïv: formuvannia pozytiï na tli katastrofy," Ukrä̈na Moderna 13 (2008): 252-265. 
28. John-Paul Himka. "War Criminality: A Blank Spot in the Collective Memory of the Ukrainian Diaspora," Spaces of Identity 5 (2005): 16-17.

29. O. Mytsiuk, “Ahraryzatsiia zhydivstva za dobu bol'shevyzmu,” Rozbudova Natsï, no. 7-8 (1933): 180-190, and no. 9-10,226-235; idem., "Pozaahrarna diial'nist' zhydiv po svitovii viini," Rozbudova Natsiï, no. 11-12 (1933): 277-287, cited in Kurylo, "The Jewish Question."

30. Ryszard Wysocki, Organizacja Ukraińskich Nacjonalistów w Polsce w latach 1929-1939: geneza, struktura, program, ideologia (Lublin: Wydawn. Uniwersytetu Marii Curie-Sklodowskiej, 2003), 201.

31. Kurylo, "Jewish Question,” 6, citing Iu. Mylianych, “Zhydy, sionizm i Ukraina,” Rozbudova Natsii, no. 8-9 (1929): 271.

32. Volodymyr Martynets', Zhydivs 'ka problema v Ukraïni (London: Williams, Lea \& Co., 1938), $10,14-15$.

33. Ibid., 22.

34. Kurylo, "Jewish Question,” citing R. O., "Obludnyky humanitaryzmu," Visnyk no. 1 (1939). No page number provided.

35. Kurylo, “Jewish Question,” citing M. O. [M. Ostoverkha], “Antysemityzm v Italii,” Visnyk, no. 1 (1938): 712-714.

36. Kurylo, "Jewish Question."

37. Bruder, "Den ukrainischen," 147. Several pogroms took place in Ukraine in between 1918 and 1920, during which some one hundred fifty thousand Jews were killed, an estimated 53.7 percent by Petluira's nationalist forces, 17 percent by Denikin's White Army, and 2.3 percent by the Bolshevik Red Army. Manus I. Midlarsky, The Killing Trap: Genocide in the Twentieth Century (Cambridge: Cambridge University Press, 2005), 45.

38. Karel C. Berkhoff and Marco Carynnyk, "The Organization of Ukrainian Nationalists and Its Attitude towards Germans and Jews: Iaroslav Stets'ko's 1941 Zhyttiepys," Harvard Ukrainian Studies 23, no.3-4 (1999): 149-184; Kurylo and Himka "Iak OUN stavylasia do ievreiv?" 252-265; John-Paul Himka, "A Central European Diaspora under the Shadow of World War II: The Galician Ukrainians in North America," Austrian History Yearbook 37 (2006): 22; Kurylo, "Jewish Question"; H. V. Kasianov, "Ideolohiia OUN: istoryko-retrospektyvnyi analiz," Ukrains 'kyi istorychnyi zhurnal, no. 2 (2004): 38-39.

39. Karel Berkhoff, Harvest of Despair: Life and Death in Ukraine under Nazi Rule (Cambridge, Mass.: Harvard University Press, 2004), 83.

40. Stanislav Kul'chyts'kyi et al., eds., OUNv 1941 rotsi. Dokumenty. V2-kh ch. Ch. 1. (Kiev: Instytut Istorii Ukrainy NAN Ukrainy, 2006), 43, citing OUN v svitli postanov Velykykh Zboriv, Konferentsii ta inshykh dokumnetiv z borot'bi 1929-1955 r. [Zakordonni chastyny Orhanizatsii Ukrains'kykh Natsionalistiv] (1955), 24-47.

41. Kul'chyts'kyi, OUNv 1941 rotsi (2006), 159, 165, citing “Propahadnyvni vkazivky na peredvoennyi chas, na chas viiny i revoliutsii ta na pochatkovi dni derzhanvoho budivnytstva $\mathrm{z}$ Instruktsii Revolutsiinoho Provodu OUN (S. Bandery) dlia orhanizatsiinoho aktyvu v Ukraini na period viiny "Borot'ba i diialnist' OUN pid chas viiny," Tsentral'nyi Arkhiv Orhaniv Vlady Ukrainy (henceforth TsDAVO Ukrainy), f. 3833, op. 2, spr. 1, ark. 77-89. 
42. Iu. Mylianych, “Zhydy, sionizm i Ukraïna,”271-276; Devius [D. Dontsov], "Voiuiuchyi sionizm,” Literaturno-naukovyi visnyk, no.10 (1929): 915-918; S. Narizhnyi, "Chuzhi narody v svitli ukrain'skykh prykazok," Literaturno-naukovyi visnyk, no. 10 (1929): 921-926; Martynets', Zhydivs 'ka problema.

43. Philip Friedman, "Ukrainian-Jewish Relations During the Nazi Occupation," YIVO Annual of Jewish Social Science, 12 (1958-1959): 184; John-Paul Himka, "Krakivski visti and the Jews, 1943: A Contribution to the History of Ukrainian-Jewish Relations during the Second World War," Journal of Ukrainian Studies 21, (Summer-Winter 1996): 81-95.

44. File of Mikhail Dmitrievich Stepaniak, HDA SBU f. 6, d. 1510, tom 1, 1. 65.

45. Ivan Katchanovski, "Terrorists or National Heroes" Nationalities Papers (forthcoming), citing The Henry Field Papers, Franklin D. Roosevelt Library, Hyde Park, New York, box 52, folder "1964," and Pavel Sudoplatov, Spetsoperatsii: Lubianka i Kreml'1930-1950 gody (Moscow: OLMA-Press, 1998/2003), 26; Yelena Novoselova "'Stepan Bandera: As Seen by Russian and Ukrainian Researchers," Den', April 29, 2010: http://day.kiev.ua/296328/ (accessed April 30, 2010).

46. DARO, Delo Stepana Ianishevskogo, microfilm no. 124148, cited by Viktor Polishchuk, "Gora rodila mysh'. Banderovskuio," in Vladimir Vorontsov, ed., "OUN-UPA. S kem i protiv koho oni voevali": istoriko-dokumental'nye ocherki (Sevastopol: Mezhregional'naia obshchestvennaia organizatsiia "Ob'edinenie patriotov Sevastopol'ia," 2011), 74; and Lucyna Kulińska, "Działność terrorystyczna ukraińskich organizacji nacjonalistycznych w Polsce w okresie międzywojennym," Biuletyn instytut pamięci narodowej, no. 7-8 (116-117) (July-August 2010): 57, n. 40.

47. File of Mikhail Dmitrievich Stepaniak, HDA SBU, f. 6, d. 1510, tom 1, 1. 67.

48. Mary Heimann, Czechoslovakia: The State That Failed (New Haven, Conn.: Yale University Press, 2009), 112.

49. Yeshayahu Jelinek, The Parish Republic: Hlinka's Slovak People's Party, 1939-1945, East European Monographs 14 (New York: Columbia University Press, 1976), 48. The anti-Semitic Slovak constitution, "Ústavný zákon zo dňa 21. Júla 1939 o ústave Slovenskej republiky," is available online, on the website of the Slovak Nation's Memory Institute: http://www.upn.gov.sk/data/pdf/ustava1939. pdf (accessed Dec. 30, 2008). Thanks to Nina Paulovicova for these references.

50. In Croatia, German support for Slovak statehood strengthened the pro-German wing of the Ustaše movement and significantly increased its production of anti-Semitic propaganda material. On the racialist ideology of the Ustaše movement, see Tomislav Dulić, Utopias of Nation: Local Mass Killing in Bosnia and Herzegovina, 1941-1942 (Uppsala: Acta Universitatis Upsalensis, 2005).

51. Heimann, Czechoslovakia,106-108; Serhii Yekelchyk, Ukraine: Birth of a Nation (Oxford: Oxford University Press, 2007), 131.

52. Mel'nyk assured von Ribbentrop that the OUN was "ideologically related to similar movements in Europe, in particular National Socialism in Germany and Fascism in Italy [weltanschaulich verwandt mit den gleichartigen Bewegungen Europas, insbesondere dem Nationalsozialismus in Deutschland und dem Fascismus in Italien].” Auswärtiges Amt Archive, PAAA, R 104430, Po. 26, No. 1m Pol. V. 4784, p. 2. Thanks to Ray Brandon for this reference.

53. The Ustaša "resurrection" of Croat statehood appears to have served as a model for the OUN. The proclamation was not delievered by Pavelić himself, but his deputy, (Doglavnik) Slavko Kvaternik. "People of Croatia! The providence of God, the will of our allies, the century-old struggle of the Croatian 
people, our self-sacrificing Leader [Poglavnik] Ante Pavelić and the Ustaša movement within and outside the country has decided that we today, on the eve of the resurrection of the son of God also will witness the resurrection of our Croatian state." Kvaternik referred to "the will of our allies," but without explicitly mentioning Hitler. Later that day, Kvaternik sent a telegram to Hitler, to thank him "in the name of the Croatian people for the protection the German army has given the Croat national rebellion and [to] request your recognition of the Independent State of Croatia by the Greater German Reich. Long live the Führer of the German people!" Zločini Nezavisne Države Hrvatske, 1941-1945 (Belgrade: Vojnoistorijski institut, 1993), document 3 (the declaration) and 4 (the telegram). Thanks to Tomislav Dulić for this reference.

54. R. J. B. Bosworth, The Oxford Handbook of Fascism (Oxford: Oxford University Press, 2009), 431.

55. 'Natsionalistychnyi rukh pid chas Druhoi Svitovoi Viiny: Interv'iu z B. Levyts'kym,” Diialoh: Za demokraiiu i sotsializm v samostiinii Ukraini, Vol. 2 (1979): 15.

56. Kul'chyts'kyi, OUN v 1941 rotsi (2006), 10. Similar attitudes were found in the OUN(b). In 1942, an OUN activist elaborated further on the size and scope of the Ukrainian state: "It will cover the lands from the Volga to the Carpathians, from the mountains of the Caucasus and the Black Sea to the sources of the Dnieper, a territory of one million square kilometers. This will be a deciding factor for the solution of the eastern problems in regards to Russia and the Baltic States, Poland, the Caucasus, the Black Sea states, and also the path to Africa and India through the Bosporus and the Dardanelles ... Ukraine for the Ukrainians! This will be a Great United National State." Derzhavnyi Arkhiv Rivenskoi oblasti, inv. nomer 326, cited in Vorontsov, "OUN-UPA,"10.

57. In 1938-1939, senior OUN functionary Colonel Roman Sushko toured Canada. According to the RCMP, Sushko "had adopted many of Hitler's mannerisms when delivering speeches." Sushko boasted that "the nationalist movement is so powerful that we will soon see the emergence of a Great Ukrainian State from the Caspian Sea to the Tatra Mountains." Orest T. Martynowych, "Sympathy for the Devil: The Attitude of Ukrainian War Veterans in Canada to Nazi Germany and the Jews, 1933-1939," in Rhonda L. Hinter and Jim Mochoruk, eds., Re-imagining Ukrainian Canadians: History, Politics, and Identity (Toronto: University of Toronto Press, 2011), 186. After the 1940 split, Sushko sided with the OUN(m). He was murdered in 1944, a murder his family attributes to the OUN(b). Myron B. Kuropas, "Who shot Col. Sushko?” The Ukrainian Weekly, March 1, $2009,7$.

58. See for instance Aristotle Kallis, Genocide and Fascism: The Eliminationist Drive in Fascist Europe (New York: Routledge, 2009), and Marius Turda, The Idea of Natonal Superiority in Central Europe, 1880-1918 (New York: Edwin Miller, 2005).

59. Mykola Stsibors'kyi, Natsiokratsiia (n.p.: Ukr. vyd-vo "Proboiem," 1942). For a discussion of natsiokratsiia, see Roman Dubasevych, "Ukraina abo smert'," in Amar, Balyns'kyi, and Hrytsak, Strasti za Banderoiu, 17-36.

60. Rossoliński-Liebe, "The "Ukrainian National Revolution," 87.

61. For Romania, see Vladimir Solonari, Purifying the Nation: Population Exchange and Ethnic Cleansing in Nazi-Allied Romania (Washington D.C.: Johns Hopkins University Press, 2010). On Slovak minority policies, see Heimann, Czechoslovakia, 112; on Croatia, see Dulić, Utopias of Nation.

62. Roman Shukhevych, leader of both the OUN(b) and the UPA, served in various Nazi German units from 1938 until 1943. He received training at the German Military Academy in Munich in 1938, in 1939-1940 he was joined by 120 other Ukrainian nationalists at a Gestapo training camp in Zakopane. Berkhoff, Harvest of Despair, 289, 298; Breitman and Goda, Hitler 's Shadow, 74, 91; Jeffrey Burds, The 
Early Cold War in Soviet West Ukraine, 1944-1948, Carl Beck Papers in Russian and East European Studies 1505 (Pittsburgh: University Center for Russian and East European Studies, 2001), 68.

63. Kul'chyts'kyi, OUN v 1941 rotsi (2006), 12 and 61, citing “'Borot'ba i diial'nist' OUN pid chas viiny: Politychni vkazivky (traven' 1941 r.)," in OUNv svitlui povstanov Velykykh Zboriv, Konferentsii ta inshykh dokumentiv z borot'bi 1929-1955 r. [Zakordonni chastyny Orhanizatsii Ukrains'kykh Natsionalistiv] (1955), 48-57.

64. Tomasz Szarota, U progu Zagłady: Zajścia antyżydowskie i pogromy w okupowanej Europie: Warszawa, Paryż, Antwerpia, Kowno (Warsaw: Wydawnictwo "Sic!" 2000), 210-214, and Peter Longereich with Dieter Pohl, ed., Die Ermordung der europäischen Juden: Eine umfassende Dokumentation des Holocaust 1941-1945 (Munich: Piper, 1989), 118-119. An analogous development also took part among profascist émigré groups in Germany. On March 19, 1941, they urged the Jews to leave Lithuania, so that "there would not be any unneccessary victims." In Berlin on May 10, 1941, the so-called Lithuanian Activist Front (LAF) presented its völkisch ideological program, which accused the Jews collectively of having destroyed Lithuania and emphasized that "communism is directly rooted in Judaism." Klaus-Peter Friedrich, "Spontane Volkspogrome oder Auswüchse der NSVernichtungspolitik?: Zur Kontroverse um die Radikalisierung der antijüdischen Gewalt im Sommer 1941,” Jewish History Quarterly (Kwartalnik Historii Żydów), no. 4 (2004): 591.

65. TsDAVO Ukrainy, f. 3833, op. 1, spr. 12, 1. 10, Telegram Iaroslav Stest'ko no. 13, 25.6.1941.

66. "Instruktsii Revolutsiinoho Provodu OUN(B) dlia orhanizatsiinoho aktyvu v Ukraini na period viiny. "Borot'ba i diial'nist' OUN pid chas viiny" V. Viis'kovi instruktsii," TsDAVO Ukrainy, f. 3833, op. 2 , spr. 1, ark. 25-33.

67. Ivan Patryliak, "Viiskovi plany OUN(B) u taemnii instruktsii Revoliutsiinoho provodu (traven' 1941 r.) "Borot'ba i diial'nist' OUN pid chas viiny," Ukrains 'kyi Istorychnyi Zhurnal', no. 2 (2000): 136.

68. "Instruktsii Revoloiutsiinoho Provodu OUN(B) dlia orhanizatsiinoho aktyvu v Ukraini na period viiny. "Borot'ba i diialnist' OUN pid chas viiny" H. Vkazivky na pershi dni orhanizatsii derzhavnoho zhyttia," TsDAVO Ukrainy, f. 3833, op. 2, spr. 1, ark. 33-57.

69. Berndt Boll, "Złoczów, July 1941: The Wehrmacht and the Beginning of the Holocaust in Galicia: From a Criticism of Photographs to a Revision of the Past," in Omer Bartov, Atina Grossmann, and Mary Nolan, eds., Crimes of War: Guilt and Denial in the Twentieth Century (New York: The New Press, 2002), 73.

70. Hannes Heer, "Einübung in den Holocaust: Lemberg Juni/juli 1941" Zeitschrift für Geschichtswissenschaft Vol. 49, 5 (2001): 409-417; Israel Gutman, "Nachtigall Battalion," Encyclopedia of the Holocaust (New York: Macmillan, 1990).

71. “Ukrains'kyi narode!” OUN(b) flyer, July 1, 1941, TsDAVO Ukrainy, f. 3833, op. 1, spr. 42, 1. 35. See also Dieter Pohl, Nationalsozialistische Judenverfolgung in Ostgalizien 1941-1944: Organization und Durchführung eines staatlichen Massenverbrechens, 2d ed. (Munich: Verlag Oldenburg, 1997), 57.

72. Kul'chyts'kyi, OUN v 1941 rotsi (2006), 11; Himka, “Central European Diaspora,”19.

73. Berkhoff and Carynnyk, "The Organization of Ukrainian Nationalists," 150.

74. Volodymyr Serhiichuk, ed., OUN-UPA v roky viiny: novi dokumenty i materialy (Kyiv: Vydavnytstvo khudozhnoi literatury “Dnipro," 1996), 239. 
75. Rossoliński-Liebe, “The 'Ukrainian National Revolution' of 1941,” 99, citing TsDAVO Ukrainy, f. 3833, op. 1, spr. 22, 11. 1-27.

76. Gabriel N. Finder and Alexaner V. Prusin, "Collaboration in Eastern Galicia: The Ukrainian Police and the Holocaust," East European Jewish Affairs, 34, no. 2 (2004): 102; Berkhoff and Carynnyk, "The Organization of Ukrainian Nationalists," 171.

77. Rossoliński-Liebe, "The 'Ukrainian National Revolution' of 1941," 100. Similar attitudes were found within the OUN(m). Its organ Selians 'ka dolia described the Jews as enemies, who "had to leave the land or die on it. The Muscovite, the Pole, and the Jew were, are, and will always be your enemies." Amir Weiner, Making Sense of War: The Second World War and the Fate of the Bolshevik Revolution (Princeton, N.J.: Princeton University Press, 2001), 242-243, citing TsDAHO Ukrainy, f. 57, op. 4, d. 369, 1. 63.

78. Heer, "Blutige Ouvertüre"; Kai Struve, "Layers of Violence: Mass Executions and Pogroms against Jews in Eastern Galicia in Summer 1941," paper presented at the Fifth Annual Danyliw Research Seminar on Contemporary Ukrainian Studies, University of Ottawa, October 30, 2009.

79. John-Paul Himka, "The Lviv Pogrom of 1941," paper presented at the Association for the Study of Nationalities, the Harriman Institute, Columbia University, 16 April 2011.

80. Bruder, “Den ukrainischen Staat,” 146, citing Pohl, Nationalsozialistische Judenverfolgung, 60 ff.; Text des Amtes Ausland/Abwehr vom Juli, 1941, IfZ, Fd 47, Bl. 47, Bl. 41; Ic/AO vom 2.7.1941, BArch-MA, RH 20-17/277, Bl. 91, 126 and 137.

81. On the pogroms, see Marco Carynnyk, Furious Angels: Ukrainians, Jews, and Poles in the Summer of 1941 (forthcoming); on the pogroms in Dubne, see idem, "The Palace on the Ikva: Dubne, September 18 $8^{\text {th }}, 1939$ and June 24th, 1941," in Elazar Barkan, Elizabeth A. Cole, Kai Struve, eds., Shared History -Divided Memory: Jews and Others in Soviet-Occupied Poland, 1939-1941 (Leipzig: Leipziger Universitätsverlag, 2007; Band V of Leipziger Beiträge zur Jüdischen Geschichte und Kultur), 263-301; on Zolochiv, see idem, "Zolochiv movchyt," Krytyka, no. 10 (2005): 14-17, on Lviv, see Himka, "Lviv Pogrom"; on Ivano-Frankivs'k, see Abraham Liebesman, During the Russian Administration: With the Jews of Stanisławow During the Holocaust (Atlanta: n.p. 1990), 2-6; Joachim Nachbar, Endure, Defy, and Remember: Memoirs of a Holocaust Survivior (Southfield, Mich.: J. Nachbar, c2003), 7-9; on Drohobych, see Bernard Mayer, Entombed: My True Story: How FortyFive Jews Lived Underground and Survived the Holocaust (Ojus, Fla.: Aleric Press, c1994), 7-16; on Borysław, Sabina Wolanski with Diana Bagnall, Destined to Live: One Woman's War, Life, Loves Remembered (London: Fourth Estate, 2008), 31-35; on Kuty, see Abraham Klein, My Life in Kuty: A shtetl destroyed (Montreal:A. Klein, 2003), 126-128. Thanks to John-Paul Himka for these references.

82. Dieter Pohl, “Anti-Jewish Pogroms in Western Ukraine: A Research Agenda," in Barkan, Cole, and Struve, eds. Shared History-Divided Memory, 305-315.

83. Viktor Khar'kiv "Khmara," a member of both Nachtigall and then Schutzmannschaft battalion 201, wrote in his diary that he participated in the shooting of Jews in two villages in the vicinity of Vinnytsia. TsDAVO Ukrainy, f. 3833, op. 1, spr. 57, ark. 17-18.

84. Bruder, "Den ukrainischen Staat,” 147.

85. Alexander Dallin, German Rule in Russia, 1941-1945: A Study of Occupation Policies, 2d ed. (Boulder, Colo.: 1981), passim. 
86. The leader of the original UPA, Taras Bul'ba-Borovets, wrote that "the supporter of pathological Führerprinzip (vozhdyzm), the banderite Kuzii, killed the two senior officers of the Ukrainian army, Colonel Mykola Stsibors'kyi and Captain Senyk-Hrybivs'kyi, who were leaders of the Provid of the OUN $[(\mathrm{m})]$ and were travelling to Kyiv, by shooting them in the back on an open street." Taras Bul'ba-Borovets', Armiia bez derzhavy: Slava i trahediia ukrains 'koho povstans 'koho rukhu. Spohady. (Kyiv: Knyha Rodu, 2008), 154. The OUN(m) immediately accused the OUN(b) of the murders, which carried all the hallmarks of Banderite assasinations. TsDAVO Ukrainy, f. 3833, op. 1, spr. 42, 1. 33, "Podae do vidoma!" claims the two OUN(m) leaders "fell by the hand of fratricidal murder"; TsDAVO Ukrainy, f. 3833, op. 1, spr. 42, 1. 42, "Dvi klespsydry," accused the OUN(b) of the murder, claiming that Stsibors'kyi and Senyk were killed by "fratricidal bullets." German documents show that there was no German involvement in these murders.

87. Grzegorz Rossoliński-Liebe, "Celebrating Fascism and War Criminality in Edmonton: The Political Myth and Cult of Stepan Bandera in Multicultural Canada," Kakanien Revisited, December 29, 2010, 3: http://www.kakanien.ac.at/beitr/fallstudie/GRossolinski-Liebe2.pdf(accessed January 9, 2011), citing Federal'naia Sluzhba Bezopasnosti, Moscow, N-19092/T. 100 1. 233 (Stepan Bandera's prison card).

88. Marples, Heroes and Villains, 129.

89. "Olevsk," entry by Jared McBride and Alexander Kruglov, Encyclopedia of Camps and Ghettoes, 1933-1945, vol. 2, German-Run Ghettos, ed. Martin Dean (Bloomington: Indidana University Press in association with the United States Holocaust Memorial Museum, forthcoming); Jared McBride, "Ukrainian Neighbors: The Holocaust in Olevs'k," unpublished working paper.

90. Bul'ba-Borovets', Armiia bez derzhavy, 247.

91. Breitman and Goda, Hitler's Shadow, 74; Marples, Heroes and Villains, 129-130, 309; Bul'baBorovets', Armiia bez derzhavy, 250-267; Report from Soviet agent "Iaroslav" to the deputy director of the third department of the GUKR NKO "Smersh," Nov. 23, 1944, HDA SBU, f. 13, sbornik no. 372 , tom $5,1.25$, reports that "the local leadership of OUN North has partly begun a struggle to totally liquidate the "Bul'ba" party and to cleanse a large part of Volhynia from Red Partisans"; "Orientovka o deiatel'nosti ukrainsko-nemetskikh nationalistiov v zapadnnykh oblastiakh Ukrainskoi SSR za period 1941-1944 g.g.: Sostavlena po materialam NKVD USSR," report from the Ukrainian SSR commissar Riasnoi of State Security, Kyiv, March 1944, HDA SBU f. 13, sbornik 372, tom 5, 199. This author uses the commonly used term OUN-UPA to describe the organization following its violent takeover by the banderivtsy, and to distinguish the post-1942 UPA from the organization led by Bul'ba-Borovets', which had a quite different orientation and ideology. The OUN(b) perceived the UPA as its armed wing; its leadership was staffed with ranking OUN(b) cadres. From May 1943 Shukhevych was the leader of both the OUN(b) and the UPA, and even the UPA's own fliers used the term "OUN-UPA." While the OUN(b)-led UPA from July 1944 was formally subordinated to the socalled Ukrainian Main Liberation Council, UVHR, this organization was staffed by the leaders of the OUN(b): Shukhevych was responsible for military matters, Lebed' for foreign affairs in the General Secretariat. Bruder, "Den Ukrainischen Staat," 189, 194, 202. Bul'ba-Borovets' dismissed the idea that the UVHR would be anything but the OUN(b) leadership under a different name as a "falsification": "UVHR was the same and only OUN Lebed'-Bandera. Its 'Council' $[$ Rada] was declared to be a new form of that same group of people, Lebed', Stets'ko, Father Hryn'okh, Roman Shukhevych, Stakhiv, Lenkavs'kyi, Vretsiun, Okhrymovych, Rebet, and others." Bul'ba-Borovets', Armiia bez derzhavy, 291. Shukhevych himself emphasized the institutional continuity of the OUN(b) and UPA: "The new revolutionary organizations UVO and OUN were born out of the traditions of insurgent struggle, which they maintained through the entire, difficult 25-year period of occupation in order to in 1943 again put into action a massive insurgency - now under the name of UPA." T. Chuprynka [Roman Shukhevych], "Zvernennia Holovnoho komamdyra UPAR. Shukhevycha do voiakiv UPA, July 1946," 
cited in Volodymyr Serhiichuk et al. eds., Roman Shukhevych u dokumentakh raiians $\mid k y k h$ orhaniv derzhavnoi bezpeky, 1940-1950, (Kyiv: PP Serhiichuk M. I., 2007), 2: 52.

92. See, for instance Martin Dean, Collaboration in the Holocaust: Crimes of the Local Police in Belorussia and Ukraine, 1941-1944 (New York: St. Martin's Press in association with the United States Holocaust Museum, 2000). See also Timothy Snyder, "To Resolve the Ukrainian Problem Once and For All: The Ethnic Cleansing of Ukrainians in Poland, 1943-1947," Journal of Cold War Studies, no. 2 (1999): 97.

93. "[An] analysis of 118 biographies of OUN(b) and UPA leaders in Ukraine during World War II shows that at least $46 \%$ of them served in the regional and local police and administration, the Nachtigall and Roland Battalions, the SS Galicia Division, or studied in German-sponsored military schools, primarily, in the beginning of World War II. At least $23 \%$ of the OUN(B) and UPA leaders in Ukraine were in the auxiliary police, Schutzmannschaft Battalion 201, and other police formations, $18 \%$ in military and intelligence schools in Germany and Nazi-occupied Poland, 11\% in the Nachtigall and Roland Battalions, $8 \%$ in the regional and local administration in Ukraine during the Nazi occupation, and $1 \%$ in the SS Galicia Division." Katchanovski, "Terrorists or National Heroes," calculated from Petro Sodol, Ukrains 'ka povstancha armiia, 1943-1949: Dovidnyk, (New York: Proloh, 1994).

94. Report No. 4-8-2034, by Pavel Sudoplatov, the leader of the third department of the fourth UPR of the NKGB of the USSR, to Kobulov, Deputy People's Commissar of the NKGB of the USSR, March 16, 1944 HDA SBU, f. 13, sbornik no. 372, tom. 5, 1. 209.

95. Reichsführer-SS, Chef der Deutschen Polizei, Chef der Bandenkampfverbände Ic.-We./Mu. Tgb. Nr. 67/44 a. H. Qu. 4 Januar 1944 lc.-Bericht über die Bandenlage ost für die Zeit von 16.12-31.12 1943, Natsional'nyi Arkhiv Respubliki Belarus'(NARB), f. 685, vop. 1, sp. 1, t. 1, 1. 8.

96. Timothy Snyder, The Reconstruction of Nations: Poland, Ukraine, Lithuania, Belarus, 1569-1999 (New Haven, Conn.: Yale University Press, 2003), 162.

97. Friedman, “Ukrainian-Jewish Relations,” 182.

98. Berkhoff, Harvest of Despair, 291.

99. Snyder, Reconstruction of Nations, 165.

100. Mykhail Dmytrievich Stepeniak file, HDA SBU, f. 6, d. 1510, tom. 1, 11. 29, 39.

101. Bruder, “Den ukrainischen Staat,” 166, citing Ereignismeldung UdSSR Nr. 126 of October 27, 1941, Meldung der Kommandeurs der Sipo und des SD in Lemberg, BArch Berlin-Lichterfelde, R $58 / 218$, B1. 323.

102. A UPA "pogrom" could look like this: "Before our military action we were given orders to kill and rob all Poles and Jews on the territory of the Dederkal's'kyi r[aio]n. I personally took part in the pogrom of Poles and Jews in the Dederlal'kyi raion in the village Kotliarovka May 10-15, 1943. There we burnt 10 Polish farmsteads, killed about 10 people, and the rest escaped." "Protokol doprosa Vozniuka Fedora Iradionovicha, 23 maia 1944," HDA SBU, f. 13, spr. 1020, ark. 221-229. Thanks to Jared McBride for this reference.

103. Bruder, "Den ukrainischen Staat,” 100, citing Kommunikat Nr. 7, Archiwum Akt Nowych, Ambasada RP w Berlinie 3677, B1. 262. 
104. Władisław Siemaszko and Ewa Siemaszko, eds. Ludobójstwo dokonane przez nacjonalistów ukraińskich na ludności polskiej Wotynia 1939-1945, 2 vols., (Warsaw: Wydawn. von Borowiecky 2000),1:872; see also 2:1269. Other UPA songs had a similar content:

\begin{tabular}{|c|c|}
\hline Zdobywaj, zdobywajmy sławę! & Let us achive our glory! \\
\hline $\begin{array}{l}\text { Wykosimy wszystkich Lachów po } \\
\text { Warszawę... }\end{array}$ & $\begin{array}{l}\text { We'll cut down all Poles [Liakhy] al } \\
\text { way to Warsaw ... }\end{array}$ \\
\hline Ukraiński narodzie. . . . & Ukrainian nation. . . . \\
\hline Zdobywaj, zdobywajmy siłę! & Gather strength! \\
\hline Zarżniemy wszystkich Lachów do mogity... & We'll butcher the Poles into their grave \\
\hline Ukraiński narodzie. . . . & Ukrainian nation. . . . \\
\hline Gdzie San, gdzie Karpaty, & From the river San, to the Carpatians, \\
\hline gdzie Krym, gdzie Kauka- & From the Crimea to the Caucasus- \\
\hline Ukraina-Ukraińcom, & Ukraine for the Ukrainians, \\
\hline a wszystkim przybłędom-precz! & All aliens must go! \\
\hline
\end{tabular}

After (the Polish translation) in ibid., 2: 1294.

Grzegorz Motyka, cites the following OUN march: "Death, death, death to the Poles/Death to the Moscow-Jewish commune/The OUN leads us into bloody battle . . . Each tormentor will face the same fate/ One gallow for Poles [Liakh] and dogs." Grzegorz Motyka, Ukraińska partyzantka 19421960: działalność Organizacji Ukraińskich Nacjonalistówi Ukraińskiej Powstańczej Armii (Warsaw: Instytut Studiów Politycznych PAN; RYTM, 2006), 54.

105. Bruder, “Den ukrainischen Staat,” 146.

106. Berkhoff, Harvest of Despair, 292.

107. Snyder, Reconstruction of Nations, 169.

108. Moshe Maltz, Years of Horrors - Glimpse of Hope: The Diary of a Family in Hiding (New York: Shengold, 1993), 147, entry for November 1944.

109. Ibid., diary entry for November 1943, 107.

110. Carynnyk, "Foes of our Rebirth"; PerA. Rudling, "Theory and Practice: Historical Representation of the Activities of the OUN-UPA," East European Jewish Affairs, 36, no. 2 (2006): 163-189.

111. John-Paul Himka, "The Ukrainian Insurgent Army and the Holocaust," paper prepared for the forty-first national convention of the American Association for the Advancement of Slavic Studies, Boston, November 12-15, 2009, 8.

112. "With the Poles gone and the Soviets approaching, UPA made a decsion to find the remaining Jewish survivors and liquidate them. As the Germans had taught them, they made assurances to Jews that they would not harm them anymore, they put them to useful work in camp-like settings, and then they exterminated them. ... These murders took place at the same time OUN was trying to make overtures to the Western Allies (as were the East European collaborationist regimes.) ... What 
is absolutely clear, however, is that a major attempt was launched at this time to eliminate Jewish survivors completely.” Ibid., 27.

113. Weiner, Making Sense of War, 264, citing interrogation of Vladimir Solov'ev, TsDAHO Ukrainy, f. 57, op. 4, d. 351, 1. 52. On UPA murder of Jews, see Shmuel Spector, The Holocaust of Volhynian Jews, 1941-1944 (Jerusalem: Yad Vashem and the Federation of Volhynian Jews, 1990), 268-273.

114. Threatened Poles sought help from the Germans, and in some cases, replaced local Ukrainians as police units. The UPA's own records from spring 1944 show how the murder of Poles continued, now on the charges that the Poles collaborated with the Gestapo. One UPA document, for the period March 13-April 15, 1944, reports 298 Poles in 19 villages were killed, many farmsteads burnt down, but a fraction of the OUN-UPA murders at the time. 'ZVit s protypol'stkykh aktiv," Postii, I. V. 44, TsDAVO, f. 4620, op. 3, spr. 378, 11. 43-44. On the OUN(b)-led UPA murder of Jews in Galicia during this period, see Himka, "The Ukrainian Insurgent Army and the Holocaust," 12-17.

115. Motyka, Ukraińska partyzantka, 295-297.

116. Himka, "The Ukrainian Insurgent Army and the Holocaust," 28.

117. According to the most extensive study of the OUN-UPA's anti-Polish campaign, the number of Polish victims reach 130,800 when including the victims whose names could not be established. Ewa Siemaszko, "Bilans Zbrodni," Biuletyn instytutu pamięci narodowej, no. 7-8 (116-117) (July-August 2010): 93.

118. Motyka, Ukrainska partyzantka, 346-347. Mixed families were quite common in the PolishUkrainian borderlands, where the custom was that boys inherited nationality after their father, girls after their mothers. Kresy literature contains many testimonies of murders within mixed families. Ewa and Wlodysław Siemaszko have registred forty-five victims of intrafamily killings in Volhynia alone. Most of the victims are known by surname. Siemaszko and Siemaszko, Ludobójstwo, 2: 1059, table 13.

119. Andrii Bolianovs'kyi, "Ivan Hryn'okh-Providnyyi diach ukrains'koho pidpillia," in Ivan Hryn'okh, Boh $i$ Ukraina ponad use, ed. and introduction by Oleksandr Panchenko (Hadiach: Vydavnytstvo "Hadiach," 2007), 64-65.

120. TsDAVO Ukrainy, f. 4628, op. 1, d. 10, 11. 170-179, in Vorontsov, “OUN-UPA,” 229.

121. Pohl, Nationalsozialistische Judenverfolgung in Ostgalizien, 376; Frank Golczewski, "Shades of Grey: Reflections on Jewish-Ukrainian and German-Ukranian Relations in Galicia," in Ray Brandon and Wendy Lower, eds., The Shoah in Ukraine: History, Testimony, Memorialization (Bloomington: Indiana University Press, 2008), 143.

122. Bruder, "Den Ukrainischen Staat," 57; Friedman, "Ukrainian-Jewish Relations," 195; Berkhoff and Carynnyk, "The Organization of Ukrainian Nationalists," 150; Breitman and Goda, Hitler's Shadow, 74, 76 .

123. Himka, "The Ukrainian Insurgent Army and the Holocaust," 28.

124. Friedman, “Ukrainian-Jewish relations,”189.

125. Spector, Holocaust, 271; Weiner, Making Sense of War, 263; Snyder, The Reconstruction of Nations 170; Dmytro Rybakov, "Marko Tsarynnyk: Istorychna napivpravda hirsha za odvertu brekhniu," Levyi bereh, November 5, 2009. http://lb.com.ua/article/society/2009/11/05/13147_marko_tsarinnik istorichna.html (accessed November 6, 2009). 
126. Spector, Holocaust, 279; Mykhailo V. Koval', Ukraina v druhii svitovyi $i$ velykyi vitchyznianyi viinakh, 1939-1945 rr., (Kyiv: Dim Al'ternatyvy, 1999), 154.

127. Interrogation of activist Mykhail Dmitrievich Stepaniak, HDA SBU, f. 6, d. 1510, tom 1, 1. 54. When working with Soviet interrogations, it is critical to keep in mind that the Soviets had special interests in demonstrating the OUN-UPA's German connections. Yet, they confirm a picture, borne out of other evidence, that Nazi Germany was but a secondary enemy of the OUN and UPA.

128. Ibid., 11. 71-72.

129. Ibid., 1. 61.

130. Report from Soviet agent "Iaroslav" to the deputy director of the third department of the USSR People's Commissariat of Defense Chief Counterintelligence Directorate "SMERSH" (Glavnoe upravlenie kontrrazvedki SMERSh GUKR-NKO, "Smersh,") Nov. 23, 1944, HDA SBU, f. 13, sbornik 372, tom 5, 1. 25.

131. Ivan Katchanovski, “Terrorists or National Heroes?” See also Stepeniak file, HDA SBU, f. 6, d. 1510 , tom 1, 11. 42, 54.

132. Special resolution passed by the Third Congress of the OUN(b) in February 1943, TsDAVO, f. 3833, op. 1, spr. 102, ark. 1-4. Thanks to Marco Carynnyk for this reference. See also Motyka, Ukraińska partyzantka, 117, n. 47.

133. The Second Congress of the OUN(b) issued detailed instructions that the fascist salue should be executed by raising the right arm "slightly to the right, slightly above the peak of the head," while exclaiming "Glory to Ukraine!" (Slava Ukraini!), to which fellow members responded "Glory to the Heroes!" (Heroiam Slava!). This section was omitted from the republished resolutions of the Second Congress. Compare, for instance, OUNv svitli postanov Velykykh Zboriv (n.p.: Zakordonni Chastyny Orhanizatsii Ukrains'kykh Nationalistiv, 1955), 44 -45, with the original 1941 publication, TsDAHO, f. 1, op. 23, spr. 926, 1. 199 (Postanovy II. Velykoho Zboru Orhanizatsii Ukrains 'kykh Nationalistiv, 37), cited in Rossoliński-Liebe, “The 'Ukrainian National Revolution' of 1941,” 90.

134. Per A. Rudling, "Szkolenie w mordowaniu: Schutzmannschaft Battalion 201 i Hauptmann Roman Szuchewycz na Białorusi 1942 roku," in Bogusław Paź(ed.), Prawda historyczna a prawda polityczna w badaniach naukowych: Przykład ludobójstwa na kresach połudiowej-wschodniej Polski w latach 1939-1946, (Wrocław: Wydawnictwo uniwersytetu Wrocławskiego, 2011), 183-204.

135. Bul'ba-Borovets, Armiia bez derzhavy, 254, citing "Vidkrytyi list da Chleniuv Provodu Orhanizatsii Ukrains'kykh Natsionalistiv Stepana Bandery," Oborona Ukrainy: Chasopys'Ukrains 'koi Narodn'oi Revolutsiinoi Armii, Osoblyve vydannia ch. 1, August 10, 1943.

136. John-Paul Himka, Ukrainians, Jews and the Holocaust: Divergent Memories (Saskatoon: Heritage Press, University of Saskatchewan, 2009), 46; Kurylo and Khymka, "Iak OUN stavylosia do ievreiv?" 260.

137. Carynnyk, "Foes of Our Rebirth," citing "Nakaz Ch. 2/43, Oblasnym, okruzhnym i povitovym providnykam do vykonannia," TsDAVO, f. 3833, op. 1, spr. 43, 1. 9.

138. Himka, Ukrainians, Jews, and the Holocaust, 46- 47.

139. Document scan available on the website of the Embassy of Ukraine in Canada, http://www. ukremb.ca/canada/ua/news/detail/11684.htm (accessed January 18, 2011). 
140. Volodymyr V"iatrovych, Stavlennia OUN do ievreiv: formuvannia pozytsii na tli katastrofy (L'viv: Vydavnytstvo "MS", 2006), 73.

141. Kosyk adds Armenians, Lithuanians, Italians, Romanians, Hungarians, Germans, and Belgians. Kosyk, The Third Reich, 373-374. Some of these non-Ukrainian UPA participants appear to have been former Soviet POWs who had served as Schutzmänner but defected after Stalingrad, and other collaborators. U.S. intelligence also mentioned former members of the Slovak Hlinka Guard, former soldiers of the Ukrainian Waffen-SS division Galizien, but also "escaped German SS men." Breitman and Goda, Hitler's Shadow, 79, citing Preliminary Reports I and Informant Report 35520 [undated], National Archives and Records Administration, (henceforth NARA), RG 319, IRR TS "Banderist Activity Czechoslovakia," v. 1, D. 190425.

142. "Through resurrection and sabotage we finally broke the strengths of the Muscovite-Jewish [moskovs'ko-zhydovskyi] occupant. When the war finally broke out our partisan activities included his physical extermination and and our rise under the leadership of our leader Stepan BANDERA." Leaflet distributed in June 1942 on the occasion of the first anniversary of the Act of June 30, 1941. HDA SBU, f. 13, spr. 372, ch. 35, 1. 200. On 1947, see f. 13, op. 376, tom 4, 1. 363. On 1948, see f. 13 , op. 376 , tom $65,1.243$.

143. "To the brotherly Czech and Slovak nations," in Petro J. Potichnyj, ed., English Langauge Publications of the Ukrainian Underground, Litopys UPA, 17 (Toronto: Litopys UPA, 1988), 158.

144. For instance, an underground OUN(b) journal from 1946 describes the History of the VKP(b) as the "Bolshevik Talmud." Ukrains 'kyi robitnyk: Vydaie kraiovyi oseredok propahandy OUN, No. 1. (January 1946): 2.

145. Anna Holian, "Anticommunism in the Streets: Refugee Politics in Cold War Germany," Journal of Contemporary History, 45, no. 1 (2010): 144.

146. Ibid., 147-148.

147. "Evrei-hromadiane Ukrainy," OUN(b)-UPA leaflet written in March 1950, HDA SBU, f. 13, d. 376, tom 65, 11. 283-294.

148. Ibid., 1. 293.

149. "Protokol doprosa obviniaemo Okhrimovucha Vasilia Ostapovicha ot 5 ianvaria 1953 g.," HDA SBU, f. 5, spr. 445, t. 4, ark. 297, printed in Volodymyr Serhiichuk et al., eds., Stepan Bandera u dokumentakh radians 'kykh orhaniv derzhavnoi bezpeky, 1939-1959, (Kyiv: PP Serhiichuk M. I., 2009), 3: 385.

150. Breitman and Goda, Hitler's Shadow, 79, citing NARA, RG 319, IRR TS “Banderist Activity Czechoslovakia,”v. 2, D. 190425.

151. 'List R. Shukhevycha kerivnyku pidpillia na Volyni 'Dalekomu,' July 18, 1946, HDA SBU f. 65, spr. S-9079, t. 2 (dodatok), ark. 287 (konvert), in Serhiichuk et al., Roman Shukhevych, 2: 54.

152. Petro Poltava, “Elementy revolutsiinosti ukrains'koho natsionalizmu," Ideia i chyn, ch. 10 (1948), HDA SBU, f. 13, no. 376, t. 6, 1. 223.

153. In fact, Lutze was not even in Volhynia at the time, but was killed in a car accident in Potsdam. Motyka, Ukrainska partyzantka, 202-203. This falsification appeared with UPA veterans in the early 1950s, and is often repeated by the nationalists. Volodymyr Kosyk, Ukraina i Nimechchyna $u$ 
Druhii svitovii viini (Lviv: Naukove t-vo imeni T. Shevchenka u L'vovi, 1993), 325. "We Ukrainians are proud of the fact that ... the Chief of Staff of the German S.A. Lutze, [was] killed in course of military operations by the UPA, under the command of General Taras Chuprynka, the former Ukrainian commander of the "Nightingale Battalion." Jaroslaw Stetzko, "The Truth About Events in Lviv, West Ukraine, in June and July, 1941: An Open Letter to the "Rheinische Merkur," Cologne," The Ukrainian Review 10, no. 3 (Autumn 1963): 70.

154. R. Hryts'kiv, "Protypovstans'ka borot'ba," in Volodymyr V"iatrovych et al., UPA: Istoriia neskorennykh (Lviv: TsDVR, 2007), 281.

155. Burds, The Early Cold War, 13, citing a secret report from CIC Special Agent Vadja V. Kolombatovic to the Commanding Officer, CIC Region III, May 6, 1947, United States Army Intelligence and Security Command (INSCOM), Dossier ZF010016WJ, 1906-9.

156. Breitman and Goda, Hitler's Shadow, 77, 79, citing Special Agent Fred A. Stelling, Memorandum for the Officer in Charge, August 1, 1947, TS Organization of Banderist Movement, NARA, RG 319 , IRR Bandera, Stephan, D. 184850. The 1950 so-called Kelley Report, written by Robert F. Kelley for the United States Army, similarly estimated that perhaps 75-80 percent of the Galician DPs sympathized with the OUN(b). Robert F. Kelley, "Survey of Russian Emigration," 92-93, 106-07, 111, 116, in Lebed archives, Harvard Ukrainian Research Institute, box 1, file 12. This document was declassified on 30 October 1992. Thanks to John-Paul Himka for this reference.

157. Evhen Lozyns'kyi (1909-1977), was a local leader of the OUN(b) in the Stanislaviv area. He stood behind the June 30 Akt, but was soon arrested by the Gestapo, imprisoned in Kraków, L'viv, and Auschwitz, and released only at the end of the war. A committed totalitarian and one of Stets'ko's closest associates, Lozyns'kyi served as regional providnyk of the OUN(b) in Bavaria after the war using the nom-de-guerre Iur. Emigrating to the United States, he was detained at the border and spent four months in dentention for his alleged involvement in the planning of a terrorist act against Soviet Foreign Minister Vyshinskii. In the United States, he served on the OUN(b)'s own "court system" and as leader of the Ukrainian League of Political Prisoners. "Vypiska iz doneseniia agenta ... ot 17 avgusta 1944 goda," HDA SBU, f. 13, spr. 372, ark. 346; "Protokol doprosa obviniaemogo Okhrimovicha Vasiliia Ostapovicha ot 10 Marta 1953," HDA SBU, f. 5, spr. 445, ark. 49; "Protokol doprosa Matvienko, Mirona Vasil'evicha," HDA SBU, f. 6, spr. 56232, ark. 231-237; Mariia Lozyns'ka, “Pam"iati Ievhena Lozyns'koho (1909-1977)," Svoboda, no. 46, November 16, 2007, 29: http://www.svoboda-news. com/arxiv/pdf/2007/Svoboda-2007-46.pdf (accessed January 6, 2011).

158. As late as 1974, the RCMP investigated the "planning [of] a violent act — possibly the kidnapping of a Soviet diplomat in Canada" by the OUN(b). Inquiry 74WLO-2S-83, "Re: Acts of aggression against the Soviet Union in Canada," inquiry from the RCMP Liaison Office, Washington D.C. to CIA, Washington, DC, December 9, 1974, NARA, RG 263, E ZZ-18, Stephen Bandera Name File, v. 2; Staatsarchiv München, Staatsanwaltschaften 34887, vol. 1, 1. 59, document on the OUN in Bavaria written by Inspector Fuchs, September 13, 1960. Thanks to Grzegorz Rossoliński-Liebe for these references.

159. Heorhyi Kas'ianov, Do pytannia pro ideolohiiu Orhanizatsii Ukrains 'kykh Nationalistiv (OUN): analitychnyi ohliad (Kyiv: Instytut Istorii Ukrainy, 2003), 32; Iurii Kyrychuk, Ukrains 'kyi natsional'nyi rukh 40-50kh rokiv XX stolittia: ideolohiia ta praktyka (L'viv: Dobra sprava, 2003), 356.

160. "Protokol' doprosa obviniaemogo Okhrimovicha, Valieiia Ostapovicha ot 21 oktabria 1952 g.," HDA SBU, f. 5, spr. 445, t. 1., ark. 219.

161. Ibid., ark. 241. 
162. Ibid., ark. $44,48$.

163. Ibid., ark. 69.

164. Burds, "The Early Cold War," 16, 55-56.

165. "Stenogramma protokol doprosa Matvieiko Mirona Vasil'evicha ot 91952 g.," HDA SBU, f. 6, spr. 56232, ark. 173-179.

166. Ibid., ark. 177; Breitman and Goda, Hitler's Shadow, 83, citing [Redacted] to Director of Security, January 9, 1956, NARA, RG 263, E ZZ-18, B 6, Stephen Bandera Name File, v. 1; Chief Base Munich to Chief, SR, EGMA-19914, March 29, 1956, NARA, RG 263, E ZZ-18, B 6, Stephen Bandera Name File, v. 2, and enclosures; Deputy Director, Plans, to Department of State, July 1, 1957, NARA, RG 263, E ZZ-18, B 126, Jaroslav Stetsko Name File, v. 1; Joint US-UK Conference, January 20, 1955, NARA, RG 263, E ZZ-19, B 10, Aerodynamic: Operations, v. 12, n. 1; Director, CA to [Redacted], DIR 00782, March 2, 1956, NARA, RG 263, E ZZ-19, B 11, Aerodynamic: Operations, v. 13.

167. Breitman and Goda, Hitler's Shadow, 81, citing SR/W2 to SR-DC, EE/SSS, January 13, 1952, NARA, RG 663, E ZZ-19, B 10, Aerodynamic: Operations, v. 10, f. 1.

168. Breitman and Goda, Hitler's Shadow, 83, citing “[Redacted] to Director of Security, January 9, 1956, NARA, RG 263, E ZZ-18, B 6, Stephen Bandera Name File, v. 1; Chief of Base Munich to Chief, SR, EGMA-19914, March 29, NARA, RG 263, E ZZ-18, B 6, Stephen Bandera Name File, v. 2 and enclosures; Deputy Director, Plans, to Department of State, July 1, 1957, NARA, RG 263, E ZZ-19, B 10, Aerodynamic: Operations, v. 12, n. 1; Director, CIA to [Redacted], DIR 00782, March 2, 1956, NARA, RG 263, E ZZ-19, B 11, Aerodynamic: Operations, v. 13.

169. Breitman and Goda, Hitler's Shadow, 80-81.

170. Breitman and Goda, Hitler's Shadow, 82, citing "Our Relations with the Ukrainian Nationalists and the Crisis over Bandera," attached to EGQA-37253, March 12, 1954, NARA, RG 263, E ZZ-19, B 10, Aerodynamics: Operations, v. 10, f.2.

171. Goda and Breitman, 82, Hitler's Shadow, citing CIA/State Department - SIS/Foreign Office Talks on Operations Against the USSR, April 23, 1951, NARA, RG 263, E ZZ-19, B 9, Aerodynamics: Operations, v. 9, f. 2.

172. Breitman and Goda, Hitler's Shadow, 80.

173. Breitman and Goda, Hitler's Shadow, 83, citing “Joint US-UK Conference, January 20, 1955, NARA, RG 263, E ZZ-19, B 10, Aerodynamic: Operations, v. 12, f. 1.

174. Pavelić's exiled Ustaše movement, reorganized in 1956 as the Croatian National Liberation Movement (Hrvatski Oslobodilački Pokret, HOP), joined Stets'ko's Anti-Bolshevik Bloc of Nations, and had its European headquarters in Franco's Spain.

175. "Protokol doprosa Matvieiko, Mirona Vasil'evicha ot 14-15 iolia 1951 goda," HDA SBU, f. 6, spr. 56232, ark. 96

176. Taras Fedoriv, Batkivshchina Bandery (Staryi Uhryniv, Ukraine: Hromas'ka orhanizatsiia “Banderivs'ke zemliatsvo," 2007), 10. 
177. Slava Stetzko, "A.B.N. Ideas Assert Themselves: The 20th Anniversary of the Anti-Bolshevik Bloc of Nations (A.B.N.), 1943-1963," The Ukrainian Review 10, no. 3 (Autumn, 1963): 9, Lypovets'kyi, OUN banderivtsi, 76.

178. “Do Ponevolenykh Narodiv i ikh Emigratsii: Zvernennia IV velykoho Zboru OUN" Vyzvol'nyi shliakh: Suspil'no-politychnyi i naukovo-literaturnyi misiachnyk, kn. 10 (247), (October, 1968): 1166; S. Stetzko, "A.B.N. Ideas Assert Themselves," 9; Oleksandr Panchenko, "Peredmova," in Roman Il'nyts'kyi, Dumky pro ukrains 'ku vyzvol'nu polityku: Vstupne slovo Oleha Il'nyts 'koho (Hadiach: Vydavnytstvo 'Hadiach,' 2007), 34.

179. Father N. Bahatyr, "Molytva pid chas vidkryttia IV Velykoho Zboru OUN," Vyzvol'nyi shliakh: suspil'no-politychnyi i naukovo literaturnyi misiachnyk, Vol. 11-12 (248-249), (November-December 1968): 1267.

180. "Protokol doprosa obviniaemogo Okhrimovicha Vasilia Ostapovicha 30 oktabria 1952," HDA SBU, f. 5, spr. 445, t. 2, ark. 136. Yet, the Reagan administration maintained friendly relations with the OUN(b). In August 1983, Yaroslav Stest'ko was invited to the White House and received by President Reagan and Vice President Bush. "Ukraina staie predmetom svitovoi politiky: u 25-littia tyzhnia ponevolenykh narodiv i 40-richcha ABN," Homin Ukrainy, August 17, 1983: 1, 3; "Politychnyi aspekt vidznachennia richnyts': TPN i ABN," Homin Ukrainy, August 24, 1983: 1, 4.

181. Panchenko, "Peredmova," 32, 41.

182. Handwritten testimony by Vasyl' Kuk, "Kharakterystyka osib natsionalistychnykh seredovyshch za kordonom: Seredovyshche ZCh OUN," HDA SBU, f. 6, spr. 51895, t. 2, ark. 37.

183. "Protokol doprosa obviniaemogo Okhrimovich Vasiliia Ostapovicha ot 11 dekabria 1952 g.," HDA SBU, f. 5, spr. 445, t. 4, ark. 30.

184. Burds, The Early Cold War, 13, citing a secret report of CIC Special Agent Vadja V. Kolombatovic to Commanding Officer, CIC Region III, 6 May 1947, INSCOM Dossier ZF010016WJ, 1906-9.

185. Breitman and Goda, Hitler's Shadow, 86, Card Ref. D 82270, July 22, 1947, NARA, RG 319, E 134B, B 757, Mykola Lebed' IRR Personal File, Box 757.

186. "Protokol doprosa obviniaemogo Okhrimovicha Vasilia Ostapovicha ot 11952 g.," HDA SBU, f. 5 , spr. 445 , t. 2 , ark. 183 .

187. Holian, "Anticommunism in the Streets," 138.

188. Breitman and Goda, Hitler's Shadow, 88-89.

189. The Immigration and Naturalization Services saw in Lebed' a "clear-cut deportation case" due to his wartime record with its "wholesale murders of Ukrainians, Poles and Jewish (sic)," but he was protected by CIAAssistant Director Allen Dulles's personal intervention. Breitman and Goda, Hitler' $S$ Shadow, 86, citing NARA, RG 263, E ZZ-18, Box 80, Mykola Lebed Name File, v. 1.

190. Breitman and Goda, Hitler's Shadow, 88.

191. "Report details ties between US and ex-Nazis," Associated Press, December 10, 2010: http:// www.google.com/hostednews/ap/article/ALeqM5hJe2eJeWstJo3-tpdA7nw-vGP6Tg?docId=3faa07 027f724e5da4c1837d8c41b788 (accessed December 15, 2010). 
192. "Protokol doprosa obviniaemo Okhrimovicha Vasiliia Ostapovicha ot 21 oktiabria 1952 g.," HDA SBU, f. 5, spr. 445, t. 1, ark. 220.

193. Charles T. O'Connell, The Munich Institute for the Study of the USSR: Origin and Social Composition, Carl Beck Papers in Russian and East European Studies 808. (Pittsburgh: University Center for Russian and East European Studies, 1990), 9f, 28-32. The Ukrainian National Rada, led by Andrii Livyts'kyi, at the time consisted primarily of by Petliurites and members of the OUN(m). By cooperating with Russian anticommunists, Bandera believed that the Melnykites had "broken the united front of hostility toward so-called cooperation with . . . Muscovite imperialists and their protectors." "Pis'mo Glavaria ZCh OUN Bandera Stepana, adresovannoe 'Provodu' OUN na Ukrainskikh zamliakh, 'Provodu' OUN L'vovskogo kraia, druz'iam Chernomu i Usmikhu,' June 1955, HDA SBU, f. 13, spr. 379, t. 2, ark. 191.

194. Arch Puddington, Broadcasting Freedom: The Cold War Triumph of Radio Free Europe and Radio Liberty (Lexington: The University Press of Kentucky, 2000), 168.

195. Evhen Shtendera (b. 1924) served as commander of political education in the UPA. Serhiichuk, Stepan Bandera, 3:8-9. See also HDA SBU, f. 5, spr. 445, t. 3, ark. 100-129, published in ibid., 3: 318. After the war he became a librarian at the University of Regina, main editor of the Litopys UPA, and from 1992, an instructor at the L'viv Polytechnic Institute.

196. Wolodymyr Kosyk (b. 1924) combined his academic career with clandestine activities in the OUN(b) and its youth section, the Ukrainian Youth Association, (Spilka Ukrains'koi Molodi, SUM). After the war he taught at the Ukrainian Free University in Munich. In 1957 he led an ABN mission in Taipei, in Chiang Kai-shek's Nationalist China. He published his research both with the Ukrainian Free University in Munich and in the Banderite intellectual jounral Vyzvol'nyi shliakh. Zirka Vitoshyns'ka, "Volodymyr Kosyk: 'Politychni podii vidbuvaiut'sia ne v zamknenomu koli iakohos' narodu, a v pevnomu vnutrishn'omu i zovnishn'omu politychnomu kontksti," Dzerkalo Tyzhdnia, August 19, 2006: http://www.dt.ua/newspaper/articles/47531 (accessed January 18, 2011); S. Stetzko, "A.B.N. Ideas Assert Themselves,"11. For his research, Kosyk was awarded a gold medal from the Ukrainian Free University in Munich in 2000, and the order For Merit (Za zaslugi) of the third degree from President Yushchenko himself in 2005. He is honorary director of the Center for the Study of the Liberation Movement in L'viv.

197. Taras Hunczak (b. 1932), with his brother, sister, and father, were members of the OUN. Taras Hunczhak, Moi spohady—stezhky zhyttia (Kyiv: Dnipro, 2005), 16, 22, 30.

198. On Veryha (1922-2009) in Waffen-SS, see Vasyl' Veryha, Pid krylamy vyzvol'nykh dum (Kyiv: Vydavnytstvo imemi Oleny Telihy, 2007). His works have been published by the Canadian Institute of Ukrainian Studies. See, for instance, Wasyl Veryha, ed., The Correspondence of the Ukrainian Central Committee in Cracow and Lviv with the German authorities, 1939-1944 (Edmonton: Canadian Institute of Ukrainian Studies Press, University of Alberta, 2000).

199. Oleksa Horbatsch (1915-1997) was assistant professor at the Ukrainian Free University in Munich 1965-1967, full professor 1971-1990, professor emeritus 1991-1997. Mykola Shafoval and Roman Iremko, eds., Universitas Libera Ucrainensis: 1921-2006 (Munich: Ukrainische Freie Universität, 2006), 122. Horbatsch was proud of his service as a soldier in the Waffen-SS and a regular contributor to the veterans' journal Visti kombatanta. Bohdan Matsiv, ed., Ukrains'ka dyviziia "Halychyna": Istoryia u svitlynakh vid zasnuvannia u 1943 r. do zvil'nennia z polonu 1949 r. (Lviv: ZUKTs, 2009), 218-219, 254; Mykola Mushynka, "Ioho biohrafiia v ioho naukovykh pratsiakh: Do 75-richcha z dnia narodzhennia Prof. Oleksy Horbacha z Nimechchyny," Druzhno vpered: Shchomisiachnyi kul 'turnohromads 'kyi iliustrovanyi zhurhnal, vydae Soiuz rusyniv-ukraintsiv Slovachchyny, no. 3 (1993): 13. 
200. Petro Savaryn (b. 1926) never held an academic position, but was one of the founders of the Canadian Institute of Ukrainian Studies and chancellor of the University of Alberta 1984-87. He also served as president of the World Congress of Free Ukrainians 1983-1987, and the Alberta Progressive Conservative party. He is also active in the society of the veterans of the Waffen-SS Galizien. Petro Savaryn, Z soboiu vzialy Ukrainu: Vid Tarnopillia do Al'berty (Kyiv:KVITs, 2007), 275.

201. Ivan Hryn'okh (1909-1994), veteran and chaplain of the Nachtigall and Schutzmannschaft Battalion 201, worked at the Ukrainian Free University in Munich, as assistant professor 1974-1977, full professor 1978-1990, professor emeritus 1991-1994. Shafoval and Iaremko, Universitas Libera Ucrainensis, 122.

202. Petro Mirchuk (1913-1999) was arrested by the Germans in 1941 and spent the war in internment camps, including Auschwitz. Immediately after the war he was responsible for OUN(b) propaganda in occupied Germany. He was one of Stepan Bandera's close allies and a stern adherent of totalitarianism. Mirchuk's writings are representative of the sort of pseudo-scholarship the OUN(b) produced after the war. He received a J.D. in 1941 and a Ph.D. in 1969 from the Ukrainian Free University in Munich, and wrote several widely cited chronicles on the history of the OUN. He combined academic activities with high-ranking positions in the OUN(b). Posivnych, Zhyttia i diial'nist' Stepana Bandery, 140. Mirchuk was also used as an "expert" for the defense during the OSI hearings on deportation.

203. Markus Huss, "Male Historians in Exile: Constantly Relating to Their Background," Baltic Worlds 3, no. 1 (2010): 17-18.

204. Some of the more prominent examples are found in the writings of Mykola Riabchuk, according to whom "Ukraine is not just a 'normal' nation," but rather, "a postcolonial country shared near equally by the 'aboriginal' and 'settler' communities." Riabchuk juxtaposes the "aboriginal" Ukrainains to the Sioux population with (non-Ukrainian) "settlers" and invokes Hollywood images of Dances with Wolves. Under these conditions, Riabchuk argues that a part "of Bandera's legacy remains relevant - that of patriotism, national solidarity, self-sacrifice, idealistic commitment to common goals and values." Mykola Riabchuk, "Bandera's Controversy and Ukraine's Future," Russkii vopros, no. 1, 2010: http:// www.russkiivopros.com/?pag=one\&id=315\&kat=9\&csl=46\# edn13 (accessed April 28, 2010); idem, "Ukraine: Revisiting a 'Success Story'?” Transitions Online, issue 10/17/2006: 4. On Riabchuk's use of postcolonial rhetortic in the service of nationalism, see Rudling, "Iushchenkiv fashyst," in Amar, Balyns'kyi, and Hrytsak, Strasti za Banderoiu, 254, and Roman Dubasevych, "Dity rozpachu," zakhid. net, December 20, 2010: http://zaxid.net/article/82258/ (accessed December 20, 2010).

205. Following president Yushchenko's designation of Stepan Bandera as Hero of Ukraine in January 2010, CIUS director Zenon Kohut defended Bandera and denied the fascist nature of the OUN. Zenon Kohut, "Ukrains'kyi natsionalizm," 145-146, and Rudling, "Iushchenkiv fashyst."

206. Only in the past few years have scholars started to give these institutions serious attention. See, for instance, O'Connor, "The Munich Institute for the Study of the USSR;" Holian, "Anticommunism in the streets"; Julia Delande, "“Building a Home Abroad'-A Comparative Study of Ukrainain Migration, Immigration Policy and Diaspora Formation in Canada and Germany after the Second World War," Ph. D. Dissertation, Hamburg University, 2006; Huss, "Male Historians in Exile"; Rossoliński-Liebe, "Celebrating Fascism."

207. Frank Golczewski, “Besprechung,” Jahrbuch für Geschichte Osteuropas, 44, no. 4 (1996): 592 ff, cited in Bruder, "Den ukrainischen Staat,"12.

208. Berkhoff and Carynnyk, "The Organization of Ukrainian Nationalists," 149; Himka, "War Criminality," 11; Bruder, "Den ukrainischen Staat," 12-13; Krzysztof Łada, "Creative Forgetting: 
Polish and Ukrainian Historiographies on the Campaign against the Poles in Volhynia during World War II," Glaukopis, no. 2/3 (2005): 346; Himka, "First Escape: Dealing with the Totalitarian Legacy in the Easrly Postwar Emigration," paper presented at the Workshop on "National Politics and Population Migrations in Central and Eastern Europe," Center for Austrian Studies, University of Minnesota, Minneapolis, 7-8 April, 2006, 7; idem, "Central European Diaspora," 22; Jeffrey Burds, "Access Restrictions in Central European Archives," round table discussion at the fortieth national convention of the American Association for the Advancement of Slavic Studies, Philadelphia, November 23, 2008.

209. Thus, only in 1996 did a complete version of Stets'ko's Akt of June 30, 1941, retaining the statement that the Ukrainian state would "cooperate closely" with Nazi Germany, appear in print. Volodymyr Serhiichuk, ed., OUN-UPA v roky viiny: Novi dokumenty i materialy (Kyiv: NAN Ukrainy, 1996), 239-240. Confronted with primary documents that establish the anti-Semitic nature of the OUN, pronationalist historians have sometimes dismissed them as Soviet forgeries. See, for instance, Taras Hunczak, "Problems of Historiograhy: History and Its Sources," Harvard Ukrainian Studies 25 (2001): 129-142. For a discussion of this, see Himka and Kurylo, "Iak OUN stavylasia do ievreiv?" 253.

210. Burds, “Access Restrictions,” 2008.

211. Himka, "War Criminality," 9-24; idem, "Central European Diaspora,"17-31; Rudling, "Iushchenkiv fashyst," 237-309; Rossoliński-Liebe, "Celebrating Fascism."

212. Lew Shankowsky, "Pro problemu antysemityzmu v Ukraini," Svoboda, February 3, 1960, cited in Himka, "War Criminality," 10.

213. Berkhoff and Carynnyk, "The Organization of Ukrainian Nationalists," 152, citing Bohdan Osadczuk, "Curesy i cymesy," Zustriczi 9 (1995): 30. Yet, during the war, Osadczuk (1920-2011) published anti-Semitic material in the collaborationist press in occupied Poland. Covering the Ustaše press for Krakivs 'ki Visti, Osadczuk reported: “The mass graves in Vinnytsia, Hrvatski Narod states, is new proof of the politics of destruction that the Jews from the Kremlin have conducted among the Ukrainian people. The murdered Ukrainians again throw guilt on Stalin and his Jewish collaborators and summon the world to an implacable struggle against the Jewish-Bolshevik threat, which would like to bring upon Europe the same fate that the defenseless vicitms in Vinnytsia met." B[ohdan] O[sadchuk], "Kryvava propahanda Ukrainy: Vynnytsia v evropeis'kii presi," Krakivs 'ki visti, August 7, 1943., cited in John-Paul Himka, "Ethnicity and the Reporting of Mass Murder: Krakivs 'ki visti, the NKVD Murders of 1941, and the Vinnitsa Exhumation," paper presented at the University of Alberta Holocaust Workshop, January 14, 2005, 13.

214. Taras Hunczak, "Ukrainian-Jewish Relations during the Soviet and Nazi Occupations," in Yuri Boshyk, ed., Ukraine during World War II: History and Its Aftermath (Edmonton: CIUS, 1986), 42, 45.

215. One of the initiators of the Waffen-SS division Galizien, Kubijovyč endorsed ethnic cleansing of Ukrainian lands and published anti-Semitic material during the Holocaust. Volodymyr Kubijovyč, "Pered maiestatom nepovynnoi krovy," Krakivs'ki visti, July 8, 1941, cited in John-Paul Himka, "The Reception of the Holocaust in Postcommunist Ukraine," in Joanna Michlic and John-Paul Himka, eds., Bringing to Light the Dark Past: The Reception of the Holocaust in Postcommununist Europe (forthcoming); John-Paul Himka, "Ethnicity and the Reporting of Mass Murder," 19; Per A. Rudling, "Organized Anti-Semitism in Contemporary Ukraine: Structure, Influence and Ideology," Canadian Slavonic Papers/Revue canadienne des slavistes 48, nos. 1-2 (March-June 2006): 96.

216. Bohdan Wytwycky, "Anti-Semitism," in Volodymyr Kubijovyč, ed., Encyclopedia of Ukraine (Toronto: CIUS Press 1984), 1: 82. On Wytwycky's writings on Jews as communists and NKVD men, see Rudling, "Organized Anti-Semitism," 98-99, n. 81. 
217. Petro Mirchuk, My Meetings and Discussions in Israel: Are Ukrainians "traditionally antiSemites"? (New York: Ukrainian Survivors of the Holocaust, 1982), 121.

218. Bruder, "Den Ukrainischen Staat," 167, n 69, citing Petro Mirchuk, In the German Mills of Death, 1941-1945, 2d ed. (New York, 1985), 17.

219. Mirchuk habitually refers to Poles as “degenerates," Jews as blood-suckers, Russians as Mongols and tyrants. Mirchuk, My Meetings and Discussions in Israel, 116, 118, 121, 122. He accused Jews of controlling the U.S. courts. "What is 'Jewish justice' doing in American courts? And why 'Jewish' and not American justice? Are we a colony of theirs? It's not enough that our government gives Israel billions of our tax money each year for nothing, and now American courts must yield to Jewish demands? .. . Goebbels himself wouldn't have been able to turn the Americans against the Jews the way they did it themselves. . . I repeat again and again, not as an 'anti-Semite' but as your friend: the abuse of your influence in America for the purpose of persecuting innocent Ukrainians by accusing them of cooperation with the Germans - is merely sowing the wind. And everyone is familiar with the proverb: 'Who sows in the wind, reaps the storm!' Think over this carefully! ... I'm not threatening you with pogroms, I'm only warning you. All of those who have come to America from Eastern European counties, occupied by the Bolsheviks, know a great deal about the role of the Jews in the recent history of these lands - a role which, for your own good, it would be better to cover-up before the American public. But with these trials of 'war criminals'- the so-called murderers of innocent Jews-you're provoking them to reveal everything incriminating against the Jews. Is this what you want? These East-European émigrés have children and grandchildren, born and raised as American citizens. When you maliciously and groundlessly accuse their forbearers of imaginary crimes - and even generalize the accusation by claiming for example that all Ukrainians 'are anti-Semites' - then they, in turn, seeking to know the truth, learn from their parents about the role of the Jews in the apparatus of the bloody CheKa, GPU, NKVD, KGB; and they pass on this information to all their American acquaintances, co-workers, professors, journalists, et al. Tell me, do you really want that?” Ibid., 124-127.

\section{Mirchuk, My Meetings and Discussions in Israel, 66. (Srul is a derogarory term for Jews.)}

221. Orest Subtelny, Ukraine: A History (Toronto: University of Toronto Press, 2000), 489. This view came to have an impact also on Ukraine, as Subtelny's textbook, in Ukrainian translation, was widely used in Ukraine during the first years of independence. Marples, Heroes and Villains, 7, 23, 40-41.

222. In a discussion at the Fifth Annual Danyliw Research Seminar in Contemporary Ukrainian Studies, the Chair of Ukrainian Studies, the University of Ottawa, October 30, 2009, Potichnyj argued that Jews, killed by the UPA, were killed because they were communists. Interviewed by the Washington Post, he elaborated on this idea. "As for the killings of Jews and Poles, Potichnyj argues that no matter where guerillas fight for liberation, it's a messy affair. The Poles provoked the Ukrainians, he said. 'With respect to Jews,' he said, 'obviously, in the situation there must have taken place some killing of the Jews, although in 1943, when the UPA was quite strong, there were hardly no Jews left because the Germans had, unfortunately, killed them all off. But there were some remnants, and the remnants were either working with the Ukrainian underground or they were working with the Soviets.' Those allied with the Red partisans were obviously enemies of the underground, he said." John Pancake, "In Ukraine, movement to honor members of WWII underground sets off debate," Washington Post, January 6, 2010: A7; John Paul Himka [Ivan-Pavlo Khymka], "Chy ukrains'ki studii povynni zakhyshzhaty spadshchynu OUN-UPA?,” in Âmar, Balyns'kyi, Hrytsak, Strasti za Banderoiu, 163.

223. "What is also indisputable is that many Jews served in the Soviet secret police during that period of Soviet rule in Western Ukraine. Naturally, Himka fails to mention the Jewish complicity which may have pointed to the motive of any number of oppressors.... While being Jewish in and of itself, certainly, was not reason to be killed, being Jewish was not immunity from being attacked when you sided and 
fought with the enemy." Askold S. Lozynskyj, "Rewriting history: An evidentary persepective," Kyiv Post, February 16, 2010: http:/www.kyivpost.com/news/opinion/op_ed/detail/59650/print/ (accessed February 22, 2010).

224. Volodymyr Serhiichuk, Nasha krov — na svoii zemli (Kyiv: Ukrains'ka vydavnycha spilka, 2000), 56-57; Volodymyr Serhiichuk, Trahediia Volhyni: Prychynyi perebih pol's 'ko-ukrains 'koho konfliktuv roky druhoi svitovoi viiny (Kyiv: Ukrains'ka vydavnycha spilka, 2003). For a discussion on Serhiichuk, see Marples, Heroes and Villains, 232-233, 236-237.

225. See the interview with Volodymyr V"iatrovych, to which we will return to later. Masha Mishchenko, "Pratsivnyk SBU: My izdyly v Izrail' pobachaty dos'e proty Shukhevycha - a ioho prosto ne isnue," UNIAN, March 25, 2008: http://unian.net/news/print.php?id=242913 (accessed April 8, 2008).

226. For instance, on November 10, 2010 during the trial in Kyiv regarding the legality of Yushchenko's collective designation of the OUN and the UPA as Heroes of Ukraine, Petro Mykytovych Perepust, representing the Sumy chapter of the far-right Ukrainian National Assembly-Ukrainian National Self Defense (UNA-UNSO), justified the "murder, dismemberment, and slaughter [ $i$ ubyvaty, $i$ pyliaty, $i$ rizati — - that is done all across the world when one people fight for their independence, they kill other people.” Legal argument, case 2a-6732/10, “Za Pozovom Vitrenko Natalii Mykhailivni do Prezydenta Ukrainy shchodo vyznannia nezakonnym Ukazu Prezydenta Ukrainy vid 28 sichnia 2010 roku No. 75/2010 'Pro vshanuvannia uzhastnykiv borot'by za nezalezhnist' Ukrainy u XX stolitti,' Okruzhnyi Administratvnyi sud mista Kyeva, November 10, 2010. Press release, November 12, 2010. The proceedings are also available online: $\mathrm{http}: / \mathrm{www}$.youtube.com/watch? $\mathrm{v}=\mathrm{znQjFCNCAXg}$ (accessed November 12, 2010). Thanks to Krzysztof Janiga for this material.

227. In an interview, the 87-year-old Volhynian UPA veteran Ivan Hnatevych Kisliuk (b. 1923) presses the book Armiia bez Derzhavy, by the founder of the original UPA, into my hands, and told me to open to page 253. It reads: "In the end of July 1943 the General Staff of the UNRA issued an appeal to the Ukrainian people, in which it protested against all those measures, which were condemned as the disreputable acts of blinded totalitarians, and emphasized that the full responsibility for the crimes falls upon the leader of the OUN Bandera, Mr. Mykola Lebed'-Ruban." "See, Ruban, Jew! [zhyd!]," Mr. Kisliuk said, pointing at Lebed's Ashkenazi-sounding nom de guerre, which to him proved Jewish responsibility for the Volhyn massacres. Bul'ba-Borovets', Armiia bez derzhavy, 253. Personal interview, Kyiv-Troishchina, Ukraine, September 23, 2010.

228. Weiner, Making Sense of War, 161-172.

229. V. R. Nakhmanovych, "Bukovyns'kyi Kurin' i masovi rozsteli evreiv Kyiva voseni 1941 r.," Ukrains 'kyi istorychnyi zhurnal no. 3 (474), (May-June 2007): 90.

230. John-Paul Himka, "The Reception of the Holocaust."

231. Himka, "War Criminality"; idem, "Central European Diaspora"; Glenn Sharfman, "The Quest for Justice: The Reaction of the Ukrainian-American Community to the John Demjanjuk Trials," Journal of Genocide Research 2, no. 1 (2000): 65-87.

232. Petro J. Potichnyj was one of the few exceptions among the pronationalist scholars. He reached out to the Jewish community, aiming at a dialogue. Howard Aster and Peter Potichnyj, Jewish-Ukrainian Relations: Two Solitudes (Oakville, ON: Mosaic Press, 1983); idem, eds., Ukrainian-Jewish Relations in Historical Perspective (Edmonton: CIUS and University of Alberta, 1990). 
233. Berkhoff and Carynnyk, "The Organization of Ukrainian Nationalists," 149, 151, 152, citing Mykola Lebed', 'Orhanizatsiia protynimets'koho opouru OUN, 1941-1943 rokiv," Suchasnist', no. 1-2 (January-February 1983): 154.

234. Berkhoff and Carynnyk, "The Organization of Ukrainian Nationalists," 151, citing Wolodymyr Kosyk, "Problems of the History of OUN and UPA," Ukrainian Review 40 (Spring 1993): 26-27.

235. Petro J. Potichnyj, in Yevhen' Shtendera and Petro J. Potichnyj, eds., Litopys UPA, vol. 17, English-Language Publications of the Ukranian Underground (Toronto: Litopys UPA, 1988), 140.

236. Taras Hunczak, "Between Two Leviathans: Ukraine during the Second World War," in Bohdan Krawchenko, ed., Ukrainian Past, Ukrainian Present: Selected Papers from the Fourth World Congress for Soviet and East European Studies, Harrogate, 1990 (New York: St. Martin's Press, 1993), 99.

237. Alexander Motyl, The Turn to the Right: The Ideological Origins and Development of Ukrainian Nationalism, 1919-1929 (New York: Columbia University Press, 1980), 166.

238. Alexander Motyl, "Ukraine, Europe, and Bandera," Cicero Foundation Great Debate Paper, 10/05 (March 2010), 6: http://www.cicerofoundation.org/lectures/Alexander_J_Motyl_Ukraine_ Europe_and_Bandera.pdf 6.

239. "It makes no sense to refer to Eastern Europeans, who were regarded by the Germans as subhumans, as 'Nazi' war criminals; they were not allowed to join the Nazi Party." Myroslav Yurkevich, in "Discussion," in Bozhyk, Ukraine in World War II, 158. Yet, National Socialism attracted many Eastern Europeans. In fact, Nazi Germany categorically banned any use of swastikas and other Nazi symbols in the émigré press, as well as prohibited the use of the term "National Socialist" in the names of any Slavic émigré organizations in Germany. Iury Hrybouski, "Belaruski rukh i Niamechchyna napiaredadni i u pachatku Druhoi sus'vetnai vainy," ARCHE No. 5 (80), (May 2009): 152.

240. Hunczak, "Ukrainian-Jewish Relations," 44-45. Similarly Mykola Riabchuk describes the OUN's collaboration and anti-Semitism as "rather disputable" and relies on Motyl's definition, in which collaborators are "individuals or groups who abandon their sovereign aspirations and serve another power's goals." Mykola Riabchuk, "Bandera's Controversy and Ukraine's Future," citing Motyl, "Ukraine, Europe, and Bandera," 6.

241. Daniel Ursprung, "Faschismus in Ostmittel- und Südosteuropa: Theorien, Ansätze, Fragestellungen," in Der Einfluss von Faschismus und Nationalsozialismus auf Minderheiten in Ostmittel- und Südosteuropa, ed. Mariana Hausleitner and Harald Roth (Munich: IKGS-Verlag, 2006), 22.

242. Alexander Motyl, “Is Putin's Russia Fascist?” National Interest Online, December 3, 2007: http:// nationalinterest.org/commentary/inside-track-is-putins-russia-fascist-1888.

243. Motyl, "Is Putin's Russia Fascist?” and idem, "Surviving Russia’s Drift to Fascism," Kyiv Post, January 17, 2008: http://www.kyivpost.com/opinion/oped/28182/ (both accessed January 15, 2011). Andreas Umland has taken Motyl to task over his use of this terminology. "If we would apply Motyl's loose conceptualization of fascism to contemporary world history, we might find so many 'fascisms' that the term would lose much of its heuristic and communicative value. . . Motyl's comment is in so far unconstructive as he deprives researchers of Russian nationalism of an important analytic tool." Andreas Umland, "Is Putin's Russia Really "Fascist"? A Response to Alexander Motyl": http:/www. globalpolitician.com/print.asp?id=4341 (accessed January 15, 2011). 
244. Motyl, "Ukraine, Europe, and Bandera,"14.

245. Wilfried Jilge, "Competition Among Victims? The Image of the Other in Post-Soviet Ukrainian Narratives on World War II," in Heorhii Kas'ianov, ed., Obraz inshoho v susidnikh istoriakh: mifi, stereotypy, naukovi interpretatsii: Materialy mizhnarodnoi naukovi konferentsii, Kyiv, 15-16 hrudnia 2005 roku (Kyiv: NAN Ukrainy, Instytut istorii Ukrainy, 2008), 66.

246. This interpretation has found a receptive audience among some pro-OUN and UPA diaspora historians. See, for instance, Canadian Institute of Ukrainian Studies Director Zenon Kohut's reply to John-Paul Himka "Re: Should Ukrainian Studies Defend the Heritage of OUN-UPA?" February 12, 2010. Dominique Arel's Ukraine List, UKL 441 (Bandera-OUN and Famine Debates), February 16, 2010: http://www.ukrainianstudies.uottawa.ca/pdf/UKL441.pdf.

247. For instance, public intellectual Mykola Riabchuk sees no difficulty with the UPA cult, as long as the focus remains on their "ethical rather than ideological values" and as long as their ideology, ethnic cleansing or mass murders are not celebrated. "The UPA fighters . . . are praised first of all for their patriotism and commitment to the national-liberation cause, for their idealism and dedication, for spiritual strength and self-secrifice." Mykola Riabchuk, "Ukraine: Neither Heroes nor Villains: Review of Heroes and Villains: Creating National History in Contemporary Ukraine, by David Marples (Budapest: Central European Press, 2007)," Transitions Online, 6 February 2007.

248. See, for instance, the interview with Volodymyr V"iatrovych,. Masha Mishchenko, "Pratsivnyk SBU."

249. See, for instance Peter J. Potichnyj and Yevhen Shtendera, eds., Political Thoughts of the Ukrainian Underground, 1943-1951 (Edmonton: CIUS and University of Alberta, 1986); Himka, "War Criminality," 11. See Rudling, "Theory and Practice"; Łada, "Creative Forgetting," Marples, Heroes and Villains, 298-301; Dietsch, Making Sense of Suffering, 147-176; Grzegorz Rossoliński-Liebe, "Der polnisch-ukrainische Historikerdiskurs über den polnisch-ukrainischen Konflikt, 1943-1947," Jahrbücher für Geschichte Osteuropas 57, no. 1 (2009): 54-85.

250. Howard Aster, "Reflections on the Work of Peter J. Potichnyj," Journal of Ukrainian Studies 21, no. 1-2 (1996): 226-227. Potichnyj largely limits his focus to the period during which OUN and UPA took a more liberal and open position to national minorities. See, for instance, Potichnyj and Shtendera, Political Thoughts of the Ukrainian Underground, a collection of essays partly based upon Mykola Lebed's archives. Unsurprisingly, there is next to nothing in the Litopys UPA on the topic of the Volhynian massacres in 1943, and total silence on UPA murders of Jews.

251. Andreas Umland, "Die andere Anomalie der Ukraine: ein Parlament ohne rechtsradikale Fraktionen," Ukraine-Analysen, no. 41 (2008): 7-10. Émigré nationalists who reestablished contacts in Ukraine, used to clandestine work, were often disappointed the organization and nature of the nationalists in the old country. See, for instance, Sukhovers'kyi, Moi Spohady, 237.

252. For examples of this narrative, see Petro Sodol, "Foreigners in the UPA," Ukrainian Quarterly 58, no. 4 (2002): 342-348; Volodymyr Kosyk, "Organizational Conditions and the Initial Struggle of the Ukrainian Insurgent Army (UPA)," Ukrainian Quarterly 58, no. 4 (2002): 310-325; Volodymyr Viatrovych, [V"iatrovych] "The Communist Alliance against the Ukrainian Insurgent Army (UPA)," Ukrainian Quarterly 58, no. 4 (2002): 326-341; Herbert Romerstein, "The KGB Disinformation Campaign Against Ukrainians and Jews,” Ukrainian Quarterly 58, no. 4 (2002): 349-360.

253. Serhiichuk, Nasha krov—na svoii zemli, 3, 42, 77. 
254. Vasyl' Derevins'kyi, Stavlennia OUN(b) i UPA do susidnikh narodiv ta natsional'nykh menshyn (Kyiv: Natsional'na Akademiia nauk Ukrainy, Instytut istorii Ukrainy, 2006), 44.

255. Serhii Hrabovs'kyi, “Tak proty koho zh voiuvav Shukhevych u Bilorusi?” Ukrains 'ka Pravda: http://www.pravda.com.ua/news/2007/11/13/66774.htm (accessed November 18, 2007). On Hrabovs'kyi's celebration of OUN-UPA and Waffen-SS division Galizien, see Marples, Heroes and Villains, 231-232.

256. Hunczak, "Problems of Historiograhy," 136.

257. Morton Weinfeld, Like Everyone Else . . but Different: The Paradoxical Success of Canadian Jews (Toronto: McClelland \& Stewart, 2001), 213-214; Daniel Mendelsohn, Lost -A Search for Six of Six Million (London: HarperCollins, 2007), 99; Golczewski, "Shades of Grey," 114-155.

258. See, for example, Himka, "The Ukrainian Insurgent Army and the Holocaust," 15, citing the USC Shoah Foundation Institute for Visual History and Education, 20586 Jack Glotzer, 12-15; Spector, The Holocaust of Volhynian Jews, 358; Ahron Weiss, "Jewish-Ukrainian Relations in Western Ukraine During the Holocaust," in Peter J. Potichnyj and Howard Aster, eds., Ukrainian-Jewish Relations in Historical Perspective (Edmonton: CIUS and University of Alberta, 1990), 409-420; Weiner, Making Sense of War, 270-271.

259. See Mykola Lebed, UPA: Ukrains'ka Povstans'ka Armiia (n.p. 1946), 35-36; for other early claims on Jews in UPA, see Petro Mirchuk, Ukrains'ka Povstans 'ka Armiia, 1942-1952 (Munich: Cicero, 1953), 69-72.

260. Lebed', Ukrains 'ka Povstans 'ka Armiia, 35-36, cited in Friedman, "Ukrainian-Jewish Relations," 204.

261. Leo Heiman, "We Fought For Ukraine - the Story of Jews Within the UPA," Ukrainian Quarterly, vol. 20, no. 2 (Spring 1964): 33-44.

262. Dr. Stella Krentsbakh, "Zhyvu shche zavdiaky UPA," in Petro Mirchuk and V. Davydenko, eds., Vriadakh UPA: Zbirka spomyniv buv. Voiakiv Ukrains 'koi Povstans 'koi Armii (New York: Nakladom T-va b. Voiakiv UPA v ZDA i Kanadi, 1957), 342-349.

263. "The questionable source mentioned here is the 'memoir', allegedly by a Jewish woman named Stella Kreutzbach, in Nasha Meta, Toronto 27 and December 4, 1954; Ukrainske Slovo (Buenos Aires?), October 10, 1954; Kalendar Almanakh na 1957 Rik (Calendar Almanac for 1957) (Buenos Aires): 92-97. Kalendar also features an article by Dmitry Andreyewsky (pp. 88-91), in which he states that Stella Kreutzbach went to Palestine after the war, where she was later employed as a secretary in the foreign ministry, and that several weeks after the publication of her memoirs in the Washington Post (which the Ukrainian publication credited for first releasing the memoirs) she was mysteriously shot and killed. I checked the Washington Post of that period and did not find the memoirs. At my request, Dr. N. M. Gelber of Jerusalem made inquiry in the foreign ministry there; the reply was that the ministry had never had an employee by that name and that such a case of homicide was entirely unknown. Moreover, a careful analysis of the text of the 'memoirs' has led me to the conclusion that the entire story is a hoax. Similarly, the Ukrainian writer B. Kordiuk labels the story 'a mystification'; he states that 'none of the members of the UPA' known to him 'ever met or heard of her."' Philip Friedman, Roads to Extinction: Essays on the Holocaust, ed. Ada June Friedman, introduction by Salo Wittmeyer Baron (New York: Conference on Jewish Social Studies, Jewish Publication Society of America, 1980), 203-204. 
264. The Krentsbakh/Kreutzbach forgery was also discussed in the Ukrainian émigré press, where the writer Bohdan Kordiuk concorded with Friedman's conclusions: "The careful historian Friedman give the story of Dr. Stella Krentsbakh, who 'Thanks UPA for her Life,' which has been re-printed so many times, his attention, but finds nothing about her. And rightly so, since none of the UPA veterans, known by the author of these lines, either heard or knew of this legendary Stella Krentsbakh. Neither have any Jews heard of her. Hardly any one of the tens of thousands of Ukrainians refugees claim to have met this Stella Krentsbakh. The biography, attributed to her in certain places, does not hold up to critical scrutiny; claims that she would have been working in the Ministry of Foreign Affairs do not correspond to the truth. And some were nonsensical claims - that she would have been killed on the streets of Jerusalem from a shot to the nape of her neck, supposedly due to her favorable memories of the UPA. That nonsense constitutes a jungle of the prejudices which so burden Ukrainian-Jewish relations. It seems to us, that as long as there is still no independent evidence, the stories of Dr. Stella Krentsbakh need to be regarded as a mystification." Bohdan Kordiuk, "Retsenzii: Pro liudei, spovnennykh samoposviaty: Their Brother's Keepers by Philip Friedman. With a Foreword by Father John A. O'Brien. Crown Publishers, Inc. New York, 1957, pp. 224," Suchasna Ukraina (Munich) 15 (194), July 20, (1958): 7.

265. Tatiana Zhurzhenko, "The Geopolitics of Memory," Eurozine, May 10, 2007. Available online: http://www.eurozine.com/articles/2007-05-10-zhurzhenko-en.html (accessed November 9, 2010).

266. Dietsch, Making Sense of Suffering, 223-226.

267. Andreas Umland and Anton Shekhovtsov, "Pravoradikal'naia partiinaia politika v postsovetskoi Ukraine: zagadka elektoral'noi marginal'nosti ukrainskikh ul'tranatsionalistov v 1994-2009 gg.," Ab Imperio, no. 2 (2010): 219-247.

268. Johan Dietsch, "Imagining the Missing Neighbor: Jews and the Holocaust in Ukrainian History Textbooks," in Heorhii Kas'ianov, Obraz inshoho v susidnikh istoriakh: mifi, stereotypy, naukovi interpretatsii: Materialy mizhnarodnoi naukovi konferentsii, Kyiv, 15-16 hrudnia 2005 roku (Kyiv: NAN Ukrainy, Instytut istorii Ukrainy, 2008), 202, citing David Levy and Nathan Sznaider, "Memory Unbound: The Holocaust and the Formation of Cosmopolitan Memory," European Journal of Social Theory, Vol. 5, No. 1 (2002): 100.

269. Wilfried Jilge, “Zmanannia zhertv,” Krytyka, vol. 10, no. 5 (May, 2006): 14-17.

270. Ihor Yukhnovs'kyi (b. 1925) is a physicist, not a trained historian. An enthusiastic admirer of Bandera and Shukhevych, the OUN and UPA, Yukhnovs'kyi has occasionally voiced antiSemitic views. Aleksandr Burakovs'kyi, "Key Characteristics and Transformation of JewishUkrainian Relations during the Period of Ukraine's Independence, 1991-2008," Nationalism and Ethnic Politics, 15, no. 1 (2009): 121; Zenon Zawada, "Kyiv conference focuses on World War II and hisotrical memory," Ukrainian Weekly, no. 44, November 1, 2009, 18. On Yukhnovs'kyi's sympathies for the "Social Nationalists," see Lilia Kuzik, "Ihor Iokhnovs'kyi: Ta derzhava zh mala utvorytysia. I ia robiv, shchob vona utvorylas'," Zaxid.net, August 11, 2011. http://zaxid.net/home/ showSingleNews.do?igor_yuhnovskiyta_derzhava_zh_mala_utvoritisya_i ya vse_robiv_shhob vona utvorilas\&objectId $=1233429$ (accessed October 2 , 2011) The Social-Nationalist Party of Ukraine (SNPU) mobilized the neo-fascist right and used an SS symbol as party emblem. In 2004 it was renamed the All-Ukrainian accociation Svoboda. Anton Shekhovtsov, "The Creeping Resurgence of the Ukrainian Radical Right? The Case of the Freedom Party," Europe-Asia Studies, Vol. 63, No. 2, (March 2011): 213.

271. Lypovets'kyi, OUN banderivtsi, 84 . 
272. OUN(b) veteran Volodymyr Kosyk serves as its honorary director, and Petro Sodol (b. 1935), a former president of the OUN(z)-affiliated publishing house Prolog in New York and a senior member of the Ukrainian nationalist youth organization Plast. http://upa.in.ua/book/?page id=5\#zabilyj (accessed December 15, 2010). On Plast and SUM in the diaspora, see Per A. Rudling, "Multiculturalism, Memory, and Ritualization: Ukrainian Nationalist Monuments in Edmonton, Alberta," Nationalities Papers, Vol. 39, no. 5 (September, 2011): 738-739.

273. For a list of the TsDVR's intellectual collaborators and partners, see http://cdvr.org.ua/content/ партнери (accessed October 1, 2011)

274. News release of the Center for the Research of the Liberation Movement, TsDVR, Informatsiina dovidka; http://upa.in.ua/book/?page_id=7 (accessed December 15, 2010).

275. Sofia Hrachova, "Unknown Victims: Ethnic-Based Violence of the World War II Era in Ukrainian Politics of History after 2004," paper presented at the Fourth Annual Danyliw Research Seminar in Contemporary Ukrainian Studies, Chair of Ukrainian Studies, University of Ottawa, October 23-25, 2008, 9 .

276. Endorsement by "Ihor Yukhnovs'kyi, Academician, head of the Ukrainian Institute of National Memory," in Volodymyr V'iatrovych, ed., Ukrains'ka Povstans'ka Armiia: Istoriia neskorenykh (Kyiv: Tsentr doslidzhen' vyzvol'noho rukhu, 2007), back cover.

277. "Instytut natsional'noi pam"iati zvernuvsia do Iushchenka, aby vin prysvoiv Romanu Shukhevychu zvannia Heroia Ukrainy," Zik: syla informatsii, July 2, 2007: http://zik.com.ua/ua/ news/2007/07/02/80305 (accessed October 15, 2010).

278. On the state honoring of Stets'ko, see Viktor Yushchenko, "Ukaz prezydenta Ukrainy No. 416/2007 Pro vshanuvannia pam'iati Iaroslava Stets'ka i Iaroslavy Stets'ko": http:/www.president.gov.ua/ documents/6145.html (accessed April 10, 2008). On the cult of Shukhevych, see Per A. Rudling, "The Shukhevych Cult in Ukraine: Myth Making with Complications," World War II and the (Re)Creation of Historical Memory in Contemporary Ukraine, Kyiv, September 25, 2009. Available online http:// ww2-histroricalmemory.org.ua/abstract e.html (accessed October 11, 2009). On Bandera, see Amar, Balyns'kyi, and Hrytsak, Strasti za Bañderoiu. In December 2010, the Kyiv city council declared that they will rename city streets after Shukhevych, Stest'ko, and Mel'nyk. "Na Oboloni z"'iavyt'sia vulitsia Romana Shukhevycha," Ukrains'ka pravda: Istorychna pravda, December 16, 2010: http:// www.istpravda.com.ua/short/2010/12/16/9227/ (accessed December 17, 2010).

279. Swedish historian Göran B. Nilsson describes the Soviet practice of writing history from the perspective of a constantly changing present as "chronological imperialism." Göran B. Nilsson, "Historia som humaniora," Historisk Tidsskrift no. 1 (1989): 1, 4.

280. To commemorate the centennial of the birth of the OUN poet Olena Teliha, President Yushchenko in 2006 issued a presidential decree to erect a memorial "to her and her associates" in Babin Yar, where her body had been buried in 1942. Aleksandr Burakovs'kyi, "Istoriia memoralizatsii evreiskoi tragedii v Bab'em Iaru za god ee 70-letiia: pozor Ukrainy," My Zdes', no. 278: http://www.newswe. $\mathrm{com} /$ index.php?go=Pages\&in=view\&id=2725 (accessed October 3, 2010), citing Yushchenko decree No. 416/2006. In Drohobych, a monument to Bandera has been erected at the site of the former ghetto. Omer Bartov, Erased: Vanishing Traces of Jewish Galicia in Present-Day Ukraine (Princeton, Conn.: Princeton University Press, 2007), 52-53.

281. Jilge, “Zmanannia zhertv,” 14. 
282. V"iatrovych, Stavlennia OUN do ievreiv.

283. There is no shortage of such memoirs. See for example Shimon Redlich, Together and Apart in Brzezany: Poles, Jews and Ukrainians, 1919-1945 (Bloomington: Indiana University Press, 2002), 103-104; Reuben Ainsztein, Jewish Resistance in Nazi-Occupied Eastern Europe: With a Historical Survey of the Jew as Fighter and Soldier in the Diaspora (London: Paul Elek, 1974), 252-256. On the OUN's and the UPA's attitude to Jews during the war, see Weiner, Making Sense of War, 239-297.

284. A Wehrmacht intelligence report from April 1944 reports that "the UPA has successfully taken up pursuit of the Jewish gangsters and up to now shot almost 100." Staatsanwaltschaft Dortmund 45 Js 24/62, Bd "Reste von Gutachten und Dokumenten aus dem Bestand des Pz. AOK 4," BA-MA, RH-21, Pz. AOK 4, Abt. Ic/AO, Tätigkeitsbericht, April 1944, as cited in Golczewski, "Shades of Grey," 143. On this topic, see Weiner, Making Sense of War, 263-264.

285. Pres-tsentr Sluzhba bezpeki Ukrainy, “U Sluzhby bezpeky Ukrainy vidbulys' Hromads'ki istorychni slukhannia "Evrei v Ukrains'komu Vyzvol'nomu ruzi," April 14, 2008, http://www.sbu. gov.ua/sbu/control/uk/publish/article?art_id=77689\&cat_id=39574 (accessed April 14, 2008).

286. Iryna Ehorova, "Volodymy V"iatrovych: Holovnym sub'ektom istorychnoho protsesu v Ukraïni XX stolittia bula ne URSR, a ukraïns'kyi vyzvol'nyi rukh,” Den', February 18, 2008: http://www. ukrnationalism.org.ua/interview/?n=69 (accessed March 16, 2008).

287. John-Paul Himka, "True and False Lessons from the Nachtigall Episode," Brama, March 19, 2008: http://brama.com/news/press/2008/03/080319himka_nachtigall.html (accessed March 19, 2008). See also Kurylo and Himka [Khymka], "Iak OUN stavylasia do ievreiv?" 252-265.

288. V"iatrovych, Stavlennia OUN, 78-81. At the April 2008 conference at the SBU, V"iatrovych repeated his argument on the SBU website, adding an additional example of a Jew in the UPA, LeibaItsko Dobravs'kyi. "U Sluzhby bezpeki Ukrainy."

289. V"iatrovych, Stavlennia OUN, 74, citing R. Petrenko, “Za Ukrainu, za ii voliu. Spohady,” Litopys Ukrains 'koi Povstans 'koi Armii, 27 (Toronto and Lviv: Litopys UPA, 1997), 173.

290. Himka, Ukrainians, Jews, and the Holocaust, 47.

291. As of January 2011, the documents were still available on the website of the Ukrainian Embassy in Canada, "Novini," Posol'stvo Ukrainy v Kanadi, February 6, 2008: http://www.ukremb.ca/canada/ ua/news/detail/11684.htm (accessed January 18, 2011).

292. Iaryna Iasynevych, "V"iatrovych: 'Kampania proty Shukhevycha ne maie istorychnoi osnovy," Narodna Pravda, March 4, 2008: http://narodna.pravda.com.ua/history/47cd371e88b05/ (accessed March 16, 2008).

293. Volodymyr V"iatrovych, "Iak tvorylasia lehenda pro Nakhtihal'," Dzerkalo Tyzhnia, no. 6 (685) 16-22 February 2008: http://www.dt.ua/3000/3150/62036/ (accessed March 16, 2008)

294. Mishchenko, "Pratsivnyk SBU."

295. SBU, “U Sluzhbi bezpeky Ukrainy vidbulys' Hromads'ki istorychni slukhannia 'Evrei v Ukrains'komu vyzvol'nomu rusi,' April 14, 2008: http://www.sbu.gov.ua/sbu/control/uk/publish/ article?art_id=77689\&cat_id=39574 (accessed April 14, 2008). 
296. Wilfried Jilge, "Nationalukrainischer Befreiungskampf: Die Umwertung des Zweiten Weltkrieges in der Ukraine," Osteuropa 58, (2008): 179.

297. SBU, “U Sluzhbi bepeki Ukrany vidkrylas' fotovystavka 'Ukrains'ka Povstans'ka Armiia. Istoria neskorennykh," May 27, 2008: http://www.sbu.gov.ua/sbu/control/uk/publish/article?art $\mathrm{id}=78839$ \&cat_id=78711 (accessed August 21, 2008).

298. V"iatrovych, Stavlennia OUN, 96, citing HDA SBU, f. 13, spr. 376, tom 65, ark. 283-295; SBU, "Evrei v Ukrains'komu vyzvol'nomu rusi."

299. SBU, "Sluzhba bezpeki Ukrainy vidkryvae dlia shyrokoho zahalu arkhivni materially shchodo osib, prychetnykh do orhanizatsii ta zdiisnennia politiki Holodomoru-Henotsydu represii": http:// www.sbu.gov.ua/sbu/control/uk/publish/article?art_id=80420\&cat_id=395 (accessed August 7, 2008).

300. SBU, 'U Sluzhbi bezpeki Ukrainy vidkrylas' fotovystavka ’Ukrains'ka Povstans'ka Armiia."' Iurii Shukhevych (b. 1933) is the son of UPA commander Roman Shukhevych and leader of the far-right UNA-UNSO, the Ukrainian sister party of the German neo-Nazi NPD. It is openly antidemocratic - in the 1990s its propaganda posters carried the slogan "Vote for us and you will never have to vote again."

Along with Levko Luk"ianenko (b. 1928), Shukhevych was one of the more prominent nationalist dissidents and a cause celebre for the émigré OUN. Following independence, Luk"ianenko became Ukraine's leading anti-Semite. Yushchenko designated both Iuryi Shukhevych and Luk"ianenko Heroes of Ukraine. Per A. Rudling, "Anti-Semitism and the Extreme Right in Contemporary Ukraine," in Andrea Mammone, Emmanuel Godin, and Brian Jenkins, eds., Mapping the Extreme Right in Contemporary Europe: From Local to Transnational (forthcoming); John-Paul Himka, "The Importance of the Situational Element in East Central European Fascism," East Central Europe 37 (2010): 357.

301. "Fishbein: ne dopustit' Ukrainu v NATO — spetsoperatsiia Kremlia," DELFI, July 12, 2009: http://www.delfi.ua/news/daily/foreign/fishbejn-ne-dopustit-ukrainu-v-nato---specoperaciyakremlya.d?id=467241 (accessed September 7, 2009); Svitlana Makovyts'ka, "Maestro bozhystoi movy: Ukrains'kyi poet Moisei Fishbein — pro politychnyi dal'tonizm, heniiv slova i heroiv Ukrainy," Ukraïna moloda, November 28, 2007: http:/www.umoloda.kiev.ua/number/1051/171/37785/ (accessed December 5, 2007). Fishbein repeats, almost verbatim, the same statements in subsequent interviews. Ol'ha Betko, "Poet M. Fishbein: dlia mene UPA - tse sviate," BBC Ukrainian Service, October 14, 2008.

302. For Fishbein's complete speech, see Moses Fishbein, "The Jewish Card in Russian Special Operations Against Ukraine: Paper delivered at the 26th Conference on Ukrainian Subjects at the University of Illinois at Urbana-Champaign, 24-27, June 2009: http:/www.vaadua.org/VaadENG/ News\%20eng-2009/fishbeyn2.htm (accessed November 8, 2009).

303. Fishbein, "The Jewish Card"; "Russia uses 'Jewish card' to destabilize Ukraine, Fishbein says," Ukrainian News, 25 June-July 8, 2009, 6; and Marko Levytsky, "UPA detractors fan the flames of ethnic discord," Ukrainian News, February 18-March 3, 2010, 6.

304. Moses Fishbein, "The Jewish ard in Russian Operations against Ukraine," Kyiv Post, June 30, 2009: http://www.kyivpost.com/opinion/44324 (accessed September 7, 2009).

305. Paul Goble, "Window on Eurasia: Moscow Special Services Again Play the 'Jewish Card' against Ukraine, Kyiv writer Says," Window on Eurasia, July 9, 2009: http://windowoneurasia.blogspot. com/2009/07/window-on-moscow-special.html (accessed September 5, 2009). Goble presents himself 
as "a longtime specialist on ethnic and religious questions in Eurasia," and worked, among other things, for the U.S. State Department, the CIA, and RFE/RL until 2004, when he made a career as vice dean and director of research at several universities in the former Soviet Union.

306. Krentsbakh, "Zhivu schche zavdiaky UPA"; "Spohady Stelly Krentsbakh-'Zhyvu shche zavdlaiky UPA.' Memoirs of Stella Krenzbach - 'IAm Alive Thanks to the UPA,'” October 25, 2009, on Moisei Fishbein's blog: http://mosesfishbein.blogspot.com/2009/10/memoirs-of-stella-krenzbachi-am-alive.html (accessed October 25, 2009).

307. "Ievreika Stella Krentsbakh rozpovila, shcho vyzhyla zavdiaky UPA," Press-tsentr TsDVR, December 9, 2009: http://upa.in.ua/book/?p=929 (accessed December 15, 2010).

308. Levytsky, "UPA detractors fan the flames of ethnic discord," 6: Marco Levytsky, "Open letter villifies freedom fighters, minimizes Holodomor," Kyiv Post, May 6, 2011 http://www.kyivpost. com/news/opinion/op_ed/detail/103827/print/ (Accessed May 10, 2011) Riabchuk also repeats the $\mathrm{V}$ "iatrovych/Fishbein line that "quite a few Jews were rescued by nationalists, and some of them even joined UPA to fight both Nazis and Soviets." "Bandera's Controversy and Ukraine's Future."

309. Victor Rud, "RE: John Pancake's UPAArticle of January 6, 2010,” Open letter to the Washington Post on behalf of the Ukrainian American Bar Association, January 22, 2010, citing Fishbein, "The Jewish Card in Russian Special Operations Against Ukraine.”

310. Moses Fishbein, “Listivka UPA 'Evrei-hromadiany Ukrainy.' 1950 rik,” December 7, 2009: http://mosesfishbein.blogspot.com/2009/12/1950.html (accessed December 7, 2009).

\section{Kurylo and Himka, "Iak OUN stavylasia do ievreiv?"}

312. This is based upon V"iatrovych's most positive estimate, which includes the four named Jews, the Stella Krentsbakh/Kreutzbach forgery and her claim that she worked with twelve Jews in her sanitary unit: twenty-five Jews divided by the lowest estimate of about 25,000 UPA insurgents in 1943. V"iatrovych, Stavlennia OUN, 74-82. In order to provide a perspective here, this handful of Jewish physicians in the UPA should be put in relation to estimates that between 25,000 and 40,000 people served in the UPA in 1943-1944 and that perhaps as many as 300,000 people came through the ranks of the OUN-UPA. Marples, Heroes and Villains, 131-132, 169. The estimates of the number of people organized in the OUN and UPA varies. Stanislav Kul'chyts'kyi estimates that 400,000 people were organized by the OUN-UPA between 1929 and the middle of the 1950s, or 10 percent of the Western Ukrainian population. Stanislav Kul'chyts'kyi, "Polska problematyka w ukraińskich badaniach historii OUN-UPA," in Antypolska akcja OUN-UPA, 1943-1944: Fakty i interpretacje (Warsaw, 2003), 137, cited in Bruder, "Den ukrainischen Staat," 279. German estimates from the end of 1943 put UPA membership at 40,000. Nationalist sources claim 100,000 members, but well-substantiated estimates provide numbers between 30,000 and 40,000 soldiers. John Armstrong, Ukrainian Nationalism, 3d ed. (Englewood, Colo.: Ukrainian Academic Press, 1990), 115.

313. See, for instance the story of Ludwik Wrodarczyk, a Roman Catholic village priest in Okopy in Volhynia, a rescuer of Jews who in 2000 was designated as Righteous of Nations. The UPA kidnapped and killed him in December 1943. Maria Dębowska and Leon Popek, Duchowieństwo diecezji łuckiej: Ofiary wojny i represji okupantów, 1939-1945 (Lublin: Polihymnia Wydawnictwo Muzyczne, 2010). In Hanachevka (Hanaczów) in Galicia, the commander of the Polish self-defense, Kazimierz Wojtowicz, assisted dozens of Jews in the village. The Jews of Hanachevka organized a Jewish platoon, fighting the UPA together with the local Poles within the ranks of Armja Krajowa. Wojtowicz survived the war and was, together with his two brothers designated as Righteous of Nations. Marples, Heroes and Villains, 206; Jerzy Węgierski, W lwowskiej Armii Krajowej (Warsaw: PAX), ch. 2-7; Motyka, Ukraińska partzyantka, 382 . 
314. "Sered heroiv novoho romanu Zabuzhko 'Muzei pokynutykh sekretiv' kolysgni v'iazni tiurmy "na Lontskoho"" Press-tsentr TsDVR, December 24, 2009: http://upa.in.ua/book/?p=981\#more-981 (accessed December 27, 2010). Zabuzhko writes that V"iatrovych's center provided her with "half a bag full of working material - xero copies, DVDs, photographs and memoirs on the history of the Ukrainian Resistance - the Ukrainian Insurgent Army (UPA)." "Popil Klaasa," Ofitsiina storinka Oksany Zabuzhko, http://www.zabuzhko.com/ua/critique/ukrhellebosch.html (accessed December 27, 2010).

315. "L'vivs'ki novyny: Oksana Zabuzhko: 'Ia ne pysala istorii UPA - ia pysala lav-stori," Vysokyi zamok, January 26, 2010: http://news.lvivport.com/content/view/20694/26/ (accessed December 27, 2010).

316. Only 6 percent of Ukrainians had a "very positive" attitude toward the OUN(b), and 8 percent "basically positive," whereas 30 percent were "very negative," and 15 percent "generally negative." The attitudes to the UPA was similar, with 5 percent very positive, 8 percent generally positive, while 29 percent very negative, and 16 percent generally negative. Significantly, the attitudes within the younger generation did not differ significantly from the older; neither did the attitude within the group of highly educated differ much from the population in general. The exception was Galicia, where 62 percent of those surveyed had a positive attitude to OUN(b), and 59 to UPA. Even in Volhynia only 5 percent of respondents were very positive, and 11 percent generally positive to UPA. Asked about war criminality, 35 percent of respondents thought OUN(b) and UPA were guilty of mass murder of Ukrainians, Jews, and Poles; 6 percent of murdering people from one of these groups. Only 14 percent of respondents thought them innocent of mass murder. Ivan Kachanovs'kyi, "Ukraintsy ne veriat v mify ob OUN i UPA," Fraza: http://www.fraza.ua/print/14.10.09/76064.html (accessed January 23, 2010).

317. Asked, "How would you define your country's relation to the following groups during World War II?" 64 percent of the respondents answered that relations with Ukrainians were bad, a higher number even than Germans (63 percent) and Russians (57 percent). Wojciech Szacki and Marcin Wojciechowski. “Źli Niemcy. źli Ukraińcy: To Niemcy byli głównymi wrogami Polaków w II wojnie i to oni zadali nam najwięcej cierpień. Ale najgorzej wspominamy kontakty z Ukraińcami," Gazeta Wyborcza, August 24, 2009, 4.

318. The question, "Who was responsible for the crimes committed in Volhynia in 1943 ?" 14 percent answered "Ukrainians," while only 5 percent answered "UPA, Ukrainian nationalists, Ukrainian military formations." A full 19 percent blamed "Russians, the USSR, NKVD. Among them, 1 percent blamed "Ukrainians and Russians" and "Ukrainians executing Russian orders"; 1 percent blamed "Germans" and "Ukrainians, on German orders"; 2 percent blamed "Poles and Ukrainians," "Mutual slaughter," and "both sides"; 1 percent maintained that "Others were responsible," or that it was "unclear" who was to blame. By far the largest group, 57 percent, answered "Don't know, have not heard about it, difficult to answer." Katarzyna Makaruk, "Wołyń 1943," Komunikat z badań, Warsaw, July 2008, BS/110/2008, Centrum Badania Opini Społecznej, CBOS, 4: http://www.cbos.pl/SPISKOM.POL/2008/K_110_08. PDF (accessed December 26, 2010).

319. Andreas Umland, "Die andere Anomalie der Ukraine: ein Parlament ohne rechtsradikale Fraktionen," Ukraine-Analysen, no. 41 (2008): 7-10.

320. Ernest Renan, "What Is a Nation?” in Homi K. Bhabha, ed., Nation and Narration (London: Routledge, 1990), 11.

321. Bruno Bettelheim, The Uses of Enchantment: The Meaning and Importance of Fairy Tales (New York: Vintage, 1989), 7-8. 
322. Ibid., 9-10.

323. Harald Welzer, Sabine Moller, and Karoline Tschuggnall, "Opa war kein Nazi”: Nationalsozialismusnund Holocuast im Familiengedächtnis (Frankfurt am Main: Fischer Taschenbuch Verlag, 2002), 210.

324. Ibid., 207.

325. Ibid., 209.

326. Peter Niedermüller, "Der Mythos der Gemeinschaft: Geschichte, Gedächtnis und Politik im heutigen Osteuropa," in Andrea Corbea Hoise, Rudolf Jaworski, and Monika Sommer, eds., Umbruch im östlichen Europa: Die nationale Wende und das kollektive Gedächtnis (Innsbruck: Studien Verlag, 2004), 11-26.

327. Gudrun Persson, "On the Meaning of the Tristesse and the Lie," Baltic Worlds 3, no. 2 (June 2010): 16, citing Andrei Zubov, Istoriia Rossii: XX vek, 1894-1939 (Moscow: Astrel, 2009), 933.

328. Dmytrii Rybakov, "Marko Tsarynnyk: Istorychna napivpravda hirsha za odvertu brekhniu”; LB.ua, November 5, 2009. http://society.lb.ua/life/2009/11/05/13147_Marko_TSarinnik_Istorichna_napivp. html (Accessed Nov. 6, 2009); Himka, "True and False Lessōns; Vasyl' Rasevych, "Zamknute kolo 'spetsial'noi' ukrainskoi istorii," Zaxid.net, September 13, 2010: http://zaxid.net/article/74357 (accessed September 16, 2010).

329. In April 2007, President Yushchenko submitted to the Verkhovna Rada a draft law against Holodomor denial, which, had the law passed, would criminalize denial of the genocidal character of the famine of 1932-1933. The Day Weekly Digest (Kyiv), no. 11, April 3, 2007; Ilya Khineiko, "Russian Duma's Discussion of Second World War Revisionism in the Near Abroad States," Current Politics in Ukraine, June 23, 2009: http://ukraineanalysis.wordpress.com/ [CIUS Stasiuk Program $B \log$ ] (accessed October 2, 2009). As there is no consensus whether the famine was an act of genocide, this would, technically, have made a number of senior scholars and academics, including Mark B. Tauger, R. W. Davis, Stephen G. Wheatcroft, Michael Ellman, Lynne Viola, Moshe Lewin, even Robert Conquest - who remains ambivalent on the-liable for jail time in Ukraine. On the assessment of the famine as genocide, see Marples, Heroes and Villains, 72, 313, n. 1.

330. Roman Serbyn, "Erroneous Methods in J.-P. Himka's Challenge to "Ukrainian Myths," August 7, 2011, Current Politics in Ukraine Blog: Opinon and analysis on current events in Ukraine, Stasiuk Program, CIUS, University of Alberta, ed. David R. Marples. http://ukraineanalysis.wordpress.com/ (accessed October 1, 2011).

331. The following commentary by Taras Hunczak is fairly typical in this regard: "Despite overwhelming evidence exonerating the OUN and Roman Shukhevych, there are still individuals, particularly those with communist leanings or followers of the Moscow trend to condemn the Ukrainians' struggle for independence, who continue to slander the leaders of the Ukrainian resistance movement." Taras Hunczak, "Shukhevych and the Nachtigall Battalion: Moscow's Fabrications," Ukrainian Weekly, no. 37 (September 13, 2009): 18.

332. Ukrainian Canadian Congress, "Ukraine's President Recognized Ukraine's Freedom Fighters," UCC Press release, email of February 1, 2010. On the UCC's strategy to "defend" their heroes, see Rudling, "Iushchenkiv fashyst," 252, 295-296 and John-Paul Himka, "Interventions: Challenging the Myths of Twentieth-Century Ukrainian History," in a forthcoming Ab Imperio volume on Geschichtspolitik, sponsored by the Carnegie Foundation, ed. Alexei Miller. 
333. Pres-sluzhba Prezydenta Viktora Ianukovycha, "Rishenniam sudu prezydents'kyi ukaz 'Pro prysvoennia S. Banderi zvannia Heroi Ukrainy’ skazovano,” press release, January 12, 2011, Prezydent Ukrainy Viktor Ianukovych: Ofitsiine internet-predstavnytsvo: http://www.president.gov. ua/news/19103.html (accessed February 12, 2011).

334. "Babi Yar transferred to Culture Ministry," Ukrinform: Ukrainian National News Agency, March $2,2011$.

335. Askol'd Lozyns'kyj (b. 1952), a New York lawyer and OUN(b)-activist, is a former president of the World Congress of Free Ukrainians, and the son of Evhen Lozyns'kyj.

336. Wolodymyr Derzko, "Ukrainian Diaspora must learn how to play hardball with Yanukovych," Kyiv Post, September 27, 2010: http://www.kyivpost.com/news/opinion/op_ed/detail/84019/(accessed October 13, 2010); Askold S. Lozynskyj, "Anti-Semitism charges don't stick against Ukrainian nationalist group," Kyiv Post, December 20, 2010: http:/www.kyivpost.com/news/opinion/op_ed/ detail/93235/ (accessed December 24, 2010).

337. Olena Tregub, "Ukrainian-Americans reject meeting with Yanukovych," Kyiv Post, September 23, 2010: http://www.kyivpost.com/news/nation/detail/83599/ (accessed October 15, 2010).

338. "Paul Grod: 'My position on Ukraine . . . was agreed with leaders of UCC's member organizations," interview by Martha Onufriv, EPOSHTA, September 28, 2010: http://www.eposhta. com/newsmagazine/ePOSHTA_100928_CanadaUS.html\#fola (accessed October 15, 2010).

339. Lozynskyj, “Anti-Semitism charges don’t stick.”

340. Askold S. Lozynskyj, "How insensitive bigots continue to play Ukrainians and Jews against each other," Kyiv Post, November 8, 2010: http://www.kyivpost.com/news/opinion/op_ed/detail/89252/ (accessed November 8, 2010); Peter O’Neil, "My role in a dark conspiracy," Letter From Paris by Peter O’Neil, November 10, 2010:http://communities.canada.com/shareit/blogs/letterfromparis/default. aspx?PageIndex $=2$ (accessed November 13, 2010).

341. Lozynskyj, "Rewriting history," reprinted as Askol'd Lozyns'kyi, "Perepysuvannia istorii: z perspektyvy dokaziv," 204-210; also Rudling, "Iushchenkiv fashyst," 255, 302, both in Amar, Balyn'skyi, and Hrytsak, Strasti za Banderoiu.

342. Lozynskyj, "Anti-Semitism charges don’t stick."

343. Onufrir interview, "My position on Ukraine."

344. Peter O'Neil, "Ukrainian museum toured by Harper shows 'one-sided' history of atrocities, critics say," Edmonton Journal, November 5, 2010: http://www.edmontonjournal.com/news/Ukrain ian+museum+toured+Harper+show+sided+history+atrocities+critics/3785861/story.html (accessed November 6, 2010).

345. Rudling, "Iushchenkiv fashyst," 252-253, 296; Himka, "Interventions"

346. "Reminder to Register for the XXIII Congress in Edmonton," email from UCC to author, October $15,2010$.

347. Peter O’Neil, "Historian hopes Harper's visit to Ukraine museum will help shed light on war atrocities," The Montreal Gazette, November 10, 2010, http://www.montrealgazette.com/news/Hist orian+hopes+Harper+visit+Ukraine+museum+will+help+shed+light/3807727/story.html (accessed November 10, 2010). 
348. “Arkhivni dokumenty ruinuiut' mif pro antysemityzm OUN, - V"iatrovych," Zik: syla informatsii, http://zik.com.ua/ua/news/2011/01/09/265640 (accessed January 9, 2011)

349. Paul Grod, "Ukrainian Community Honors Veterans on Rememberence Day,” UCC Press release, November 11, 2010.

350. "Rememberance Candle Focus of Holodomor Commemorations: Canadians prepare to mark the 77th anniversary of the Ukrainian Genocide," UCC National Press release, November 16, 2010; Peter O'Neil, "Harper's Ukraine famine exaggerated, scholar says," Edmonton Journal, October 30, 2010: http://www2.canada.com/edmontonjournal/news/story.html?id=ea26329d-c6c5-4e76-b8f548ff37f57537 (accessed March 24, 2011).

351. Whereas the change of national government has effectively ended state support for the OUN cult, this sort of heroization continues on the local level. In December 2010 the Kyiv city government announced plans to rename streets after Roman Shukhevych, Iaroslav Stets'ko, Andrii Mel'nyk, and Olena Teliha. "Na Oboloni z"iavyt'sia vultrsia Romana Shukhevycha," Ukrains' ka pravda: Istorychna pravda, December 16, 2010: http://www.istpravda.com.ua/short/2010/12/16/9227/(accessed December 17, 2010).

352. "Voin UPA: Bandera-iedinyi lytsar u Evropi, khto 1941 roku skazav Hitleru 'ni'": http://aingwar.blogspot.com/ (accessed September 26, 2010).

353. Oleh Tiahnybok, "Evroparlament he vkazuvatyme Ukraini, koho vyznavaty Heroiami," February 26, 2010, Ukrains 'ka Pravda Blohy: http://blogs.pravda.com.ua/authors/tiahnybok/4b88066cc9c5f/ (accessed April 26, 2010). 
Center for Russian \& East European Studies

University Center for International Studies

University of Pittsburgh

4400 W. W. Posvar Hall

230 South Boquet Street

Pittsburgh, Pennsylvania 15260

(412) 648-8716

www.ucis.pitt.edu/crees/cbpaper.html.

Ronald Linden, Bob Donnorummo, William Chase, Andrew Konitzer, Co-Editors Eileen O’Malley, Managing Editor

Julie Tvaruzek, Editorial Assistant 